VNIVERSIDAD

BSALAMANCA

CAMPUS DE EXCELENCIA INTERNACIONAL

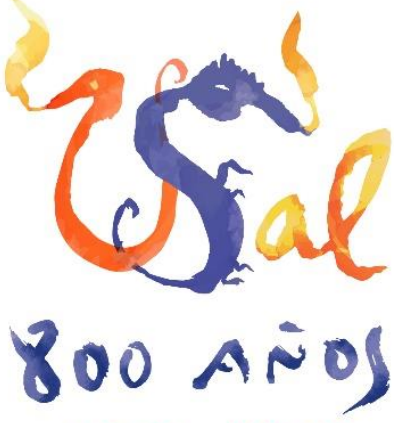

$1218 \sim 2018$

ESCUELA DE DOCTORADO 'STUDII SALAMANTINI’

Programa de Doctorado

Estado de Derecho y gobernanza global

TESIS DOCTORAL

\title{
A criminalização do enriquecimento ilícito do agente público no Brasil
}

\section{RAPHAEL MADEIRA ABAD}

Director:

Nicolás RODRÍGUEZ-GARCÍA 

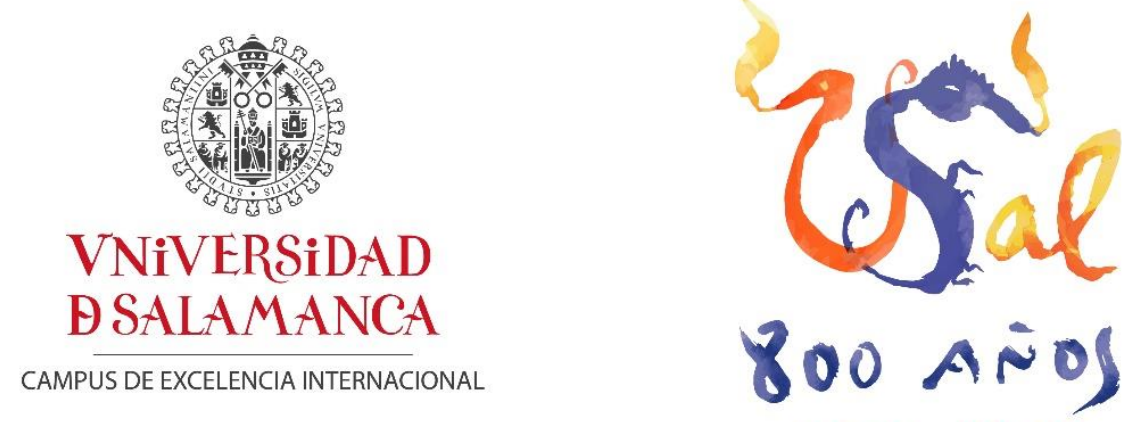

$1218 \sim 2018$

ESCUELA DE DOCTORADO 'STUDII SALAMANTINI'

Programa de Doctorado

Estado de Derecho y gobernanza global

\author{
TES IS DOCTORAL
}

\title{
A criminalização do enriquecimento ilícito do agente público no Brasil
}

\section{RAPHAEL MADEIRA ABAD}

Tesis Doctoral presentada para obtener el grado de Doctor por la Universidad de Salamanca (España), dirigida por Nicolás RODRÍGUEZGARCÍA (Catedrático de Derecho Procesal $\sim$ Universidad de Salamanca). 


\section{DEDICATÓRIA}

Dedico este trabalho a Helena Cabral Abad.

Filha querida, esta pesquisa custou muito caro, por ela troquei preciosos e efêmeros momentos da sua companhia, especialmente da sua tenra infância, beijos e risadas que nunca mais terei de volta.

Fiz na esperança de que este material possa ajudar na luta contra a corrupção, e que com isso outras crianças também possam ter saúde, educação, igualdade, segurança e sonhar com um futuro melhor. 


\section{AGRADECIMENTOS}

Inicialmente, agradeço a Larissa Crispi Cabral Abad, cujo amor e companheirismo foram fundamentais para que eu pudesse enfrentar mais este desafio, dentre tantos que esteve ao meu lado, independente do prejuízo para a nossa convivência. Meu amor, você é a pedra fundamental da nossa família e meu porto seguro em todos os momentos.

Agradeço a minha família, pelo apoio incondicional a mais este projeto, especialmente a minha mãe Alice, meu pai Thomaz, que forjaram o meu caráter, meus irmãos Carlos e Patrícia, grandes parceiros, meus sobrinhos Pedro, Alice, Gustavo, Laura, Sofia e Lucas, que representam o futuro, meus sogros Lohara e Ivan, e meus cunhados Karla e Ronaldo.

Sou extremamente grato ao povo espanhol, do qual me orgulho de ser descendente, que com seus tributos custeou muitos dos meios necessários a esta pesquisa, especialmente à magnífica Universidade de Salamanca, o que faço na pessoa do Professor Nicolás Rodríguez García por quem tive a honra de ser orientado.

Aos meus companheiros de estudos, meus fraternais agradecimentos pela acolhida e aprendizados. Obrigado Wagner, Ilo, Maurício, Luiz Henrique, Affonso, Talita, Leonardo, Diego, Vanir, Chrístian, Rodrigo Monteiro e Rodrigo Paiva.

Aos colegas do Conselho Administrativo de Recursos Fiscais do Ministério da Economia (CARF), todos verdadeiros doutores que engrandecem a administração pública federal na missão de assegurar à sociedade decisões céleres e imparciais, meus agradecimentos pela companhia durante a segunda parte desta investigação, o que faço nas pessoas dos meus colegas de Turma Gilson, Corintho, Walker, Vinícius, Jose Renato, Jorge, Denise e Paulo.

Aos colegas da Procuradoria do Município de Vitória - ES, reconhecida pela excelência na manutenção da moralidade e da probidade na administração da minha querida cidade, agradeço a todos nas pessoas do prefeito Luciano e dos meus colegas Rubem, Frederico, Alessandra, Adriana, Rafael, Mario, Roberto, Thais e Aline. 
Não poderia deixar de agradecer a todos os meus caríssimos alunos que, durante estes vinte anos foram grandes companheiros de discussões, muitos transformaram-se em valorosos amigos, especialmente os da Universidade Federal do Espírito Santo (UFES), escola onde graduei e tive a honra de iniciar a minha docência, da Universidade de Vila Velha (UVV), Faculdade de Direito de Vitória (FDV) UNIVIX, FUCAPE e FAESA. Rendo especial homenagem aos valorosos Capitães e Delegados do Curso de Aperfeiçoamento de Oficiais da Academia da Polícia Militar do Estado do Espírito Santo, a quem leciono a probidade administrativa, mas de quem aprendo preciosas lições de resiliência, dedicação e superação.

Aos camaradas com os quais tive a honra de servir no mesmo pelotão, uma grande família que o Exército me deu, recebam meu agradecimento pela companhia de todos estes anos.

Aos meus amigos, que durante este período passaram por um verdadeiro teste de resistência de amizade, agradeço profundamente pela fraternidade, pela tolerância e, principalmente, por terem acompanhado Larissa e Helena enquanto me dedicava a mais esta missão. Não ouso tentar nomear todos pelo risco de cometer injustiças por omissão, e faço por todos na pessoa de Renan José Thiebaut Neiva.

Alguns amigos foram fundamentais para a manutenção da minha sanidade durante este período, especialmente os do mar, onde reponho as minhas energias. Assim, meu muito obrigado a Suzana, Rominho, José Elias, Sardemberg e Mario Jr. Ainda na categoria sanidade, agradeço a Thais por me ajudar a manter o rumo com saúde, sabedoria e estabilidade.

Finalmente, agradeço a Deus por ter permitido que este trabalho tenha transcorrido em paz, harmonia e concórdia, já que nada acontece que não seja da Sua vontade. 


\section{ABREVIATURAS}

Abr.

Abril.

AC

Acre.

$\mathrm{ACHR}$

American Convention on Human Rights.

AG.

Agravo.

Ago.

Agosto.

AGU

Advocacia Geral da União.

Al

Anistia Internacional.

Al.

Agravo de Instrumento.

$\mathrm{AL}$

Alagoas.

AM

Amazonas.

Ampl.

Ampliada.

AP

Amapá.

AP.

Ação Penal.

AR.

Agravo Regimental.

BA

Bahia.

BB

Banco do Brasil.

BNDES

Banco Nacional do Desenvolvimento.

CAPEMI Caixa de Pecúlios Pensões e Montepios Beneficente.

CE

Ceará.

CEF

Caixa Econômica Federal.

CF

Constituição Federal.

Cf.

Conferir.

CFRB

Constituição Federal da República Brasileira.

CGU

Controladoria Geral da União.

Cit.

Citado (a).

$\mathrm{CN}$

Congresso Nacional.

COAF Conselho de Controle de Atividades Financeiras.

COE

Council of Europe.

Coord.

Coordenadores.

$\mathrm{CP}$

Código Penal.

CPI

Comissão Parlamentar de Inquérito.

$\mathrm{CPI}$

Corruption Perceptions Index. 
CVRD Companhia Vale do Rio Doce.

Des. Desembargador.

Dez. Dezembro.

DF

Distrito Federal.

DJ

Diário da Justiça.

DJE

Diário de Justiça Eletrônico.

DNA

Ácido Desoxirribonucleico .

DNIT

Departamento Nacional de Infraestrutura de Transporte.

DOJ

US Department of Justice.

$\mathrm{ECHR}$

European Convention on Human Rights.

ECTHR

European Court of Human Rights.

ES

Espírito Santo.

EU

Europe Union.

EUA

Estados Unidos da América.

FAB

Força Aérea Brasileira.

FAO

Food and Agriculture Organization.

FCPA

Foreign Corrupt Practices Act.

Fev.

Fevereiro.

FIESP

Federação das Indústrias do Estado de São Paulo.

GA

General Assembly of the United Nations.

GB

Guanabara (antigo Estado da Guanabara).

GCB

Global Corruption Barometer.

GCR

Global Corruption Report.

GO

Goiás.

GRECO

Grupo de Estados Contra a Corrupção.

$\mathrm{HC}$

Habeas Corpus.

HRCion Human Rights Commission.

HRCouncil Human Rights Council.

HRW

Human Rights Watch.

IACAC

Inter-American Convention Against Corruption.

IACionHR Inter-American Commission on Human Rights.

IACtHR

Inter-American Court of Human Rights.

IBGE

Instituto Brasileiro de Geografia e Estatística.

IPEA

Instituto de Pesquisa Econômica Aplicada. 
Jan.

Janeiro.

Jul.

Julho.

Jun.

Junho.

MA

Maranhão.

Mai.

Maio.

Mar.

Março.

MC

Medida Cautelar.

MEC

Ministério da Educação e Cultura.

MG

Minas Gerais.

Min.

Ministro(a).

MP

Ministério Público Federal.

$M P$

Ministério Público.

MPE

Ministério Público Estadual.

MS

Mato Grosso do Sul.

MT

Mato Grosso.

Nov.

Novembro.

OCDE

Organização para Cooperação e Desenvolvimento Econômico.

OEA Organização dos Estados Americanos.

OECD

Organization for Economic Co-operation and Development.

OMS

Organização Mundial da Saúde.

ONU

Organização das Nações Unidas.

Op. Cit.

Obra citada ou opus citatum.

Out.

Outubro.

$\mathrm{p}$

Página.

$P A$

Pará

PB

Paraíba

PE

Pernambuco

PI

Piauí

PIB

Produto Interno Bruto

PLS

Projeto de Lei do Senado.

PP

Partido Popular

$\mathrm{PR}$

Paraná

PROER

Programa de Estímulo à Reestruturação do Sistema Financeiro.

PSC

$$
\text { Partido Socialista Cristão. }
$$




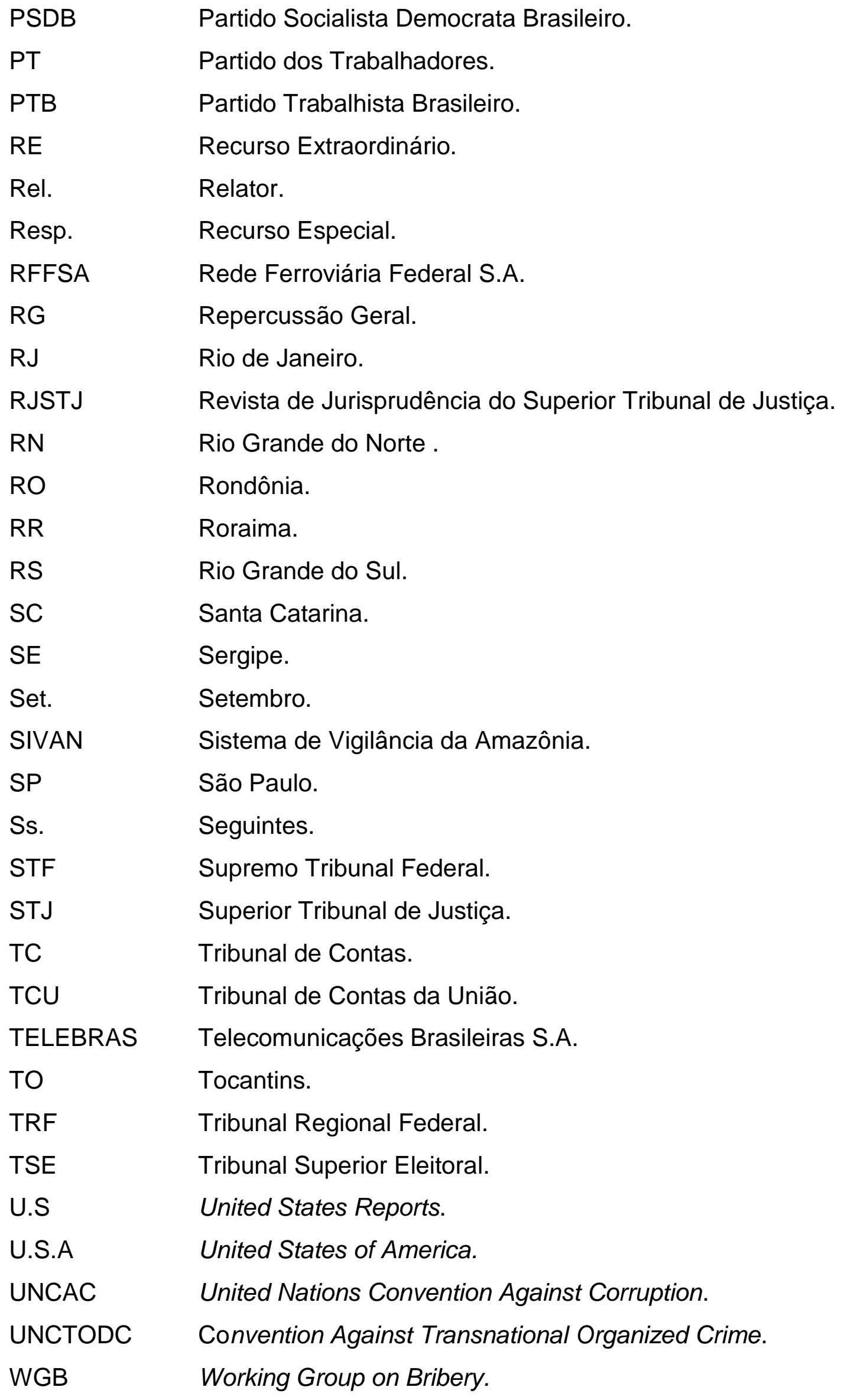




\section{RESUMO}

A presente investigação tem como objetivo analisar se o sistema processual penal brasileiro é compatível com a criminalização do enriquecimento ilícito dos agentes públicos, que se pretende estabelecer com o objetivo de erguer mais um obstáculo às práticas corruptas no Brasil, às quais é possível relacionar diversas mazelas nacionais. Para tanto será necessário conhecer os mecanismos que já foram criados para enfrentar a corrupção brasileira, adentrar nas estruturas nucleares no fato jurídico "enriquecimento ilícito do agente público" para idealizar as principais objeções que podem surgir contra este tipo penal, todas fundamentadas em princípios que de certa forma decorrem da "presunção de inocência", que por sua vez remete ao "devido processo legal" e em última análise é corolário do "estado democrático de direito", quais sejam: (i) violação ao devido processo legal pois o fato jurídico necessariamente seria provado por provas indiretas, que alegadamente não teriam "força" para ensejar uma condenação penal, e enseja um aprofundamento do conceito de provas, (ii) violação ao direito ao silêncio, pois o tipo penal não poderia levar em consideração uma manifestação do acusado sobre a origem do seu patrimônio, o que poderia violar o direito à intimidade, (iii) violação à regra da distribuição do ônus da prova no direito processual penal, segundo o qual incumbiria à acusação realizar todas as provas no sentido de estabelecer uma certeza além da dúvida razoável, (iv) violaria o princípio "in dubio pro reo", (v) seria um crime de perigo abstrato, vedado pelo direito brasileiro, (vi) seria um crime sem um "bem jurídico tutelado" e, finalmente, (vii) não ultrapassaria o postulado normativo da razoabilidade por não ser adequado, necessário e proporcional em sentido estrito. Pelo estudo foi possível concluir que a criminalização do enriquecimento ilícito, como proposto nos tratados internacionais dos quais o Brasil é signatário, e nas propostas em análise no Brasil, é compatível com as normas que regem o direito processual penal brasileiro.

PALAVRAS-CHAVE: enriquecimento ilícito, agente público, patrimônio não justificado, prova indiciária, prova indireta, processo penal, improbidade administrativa. 


\section{RESUMEN}

La presente investigación tiene como objetivo analizar si el sistema procesal penal brasileño es compatible con la criminalización del enriquecimiento ilícito de agentes públicos. La finalidad es erigir un obstáculo más a las prácticas corruptas en Brasil, a las cuales es posible relacionar varios problemas nacionales. Por tanto, será necesario conocer los mecanismos que ya se han creado para enfrentar la corrupción brasileña y entrar en las estructuras centrales del hecho jurídico "enriquecimiento ilícito del agente público" para idealizar las principales objeciones que puedan surgir contra este tipo delictivo. Estas objeciones están basadas en principios que de alguna manera tienen origen en la "presunción de inocencia", que a su vez se refiere al "debido proceso legal" y en definitiva es un corolario del "estado de derecho democrático". Estas son: (i) violación del debido proceso legal, porque ese hecho necesariamente se probaría mediante prueba indirecta, que supuestamente no tendría la "fuerza" para dar lugar a una condena penal y conduciría a una profundización en el concepto de prueba, (ii) infracción del derecho al silencio, ya que el tipo penal no podría tener en cuenta una manifestación del acusado sobre el origen de sus bienes, lo que vulneraria el derecho a la intimidad, (iii) violación a la regla de distribución de la carga de la prueba en derecho procesal penal, según el cual correspondería a la acusación realizar todas las pruebas para establecer la certeza más allá de toda duda razonable, (iv) infracción del principio "in dubio pro reo", (v) sería un delito de peligro abstracto, prohibido por la ley brasileña, (vi) sería un delito sin un "bien jurídico protegido" y, finalmente, (vii) no pasaría por las reglas del postulado normativo de razonabilidad, por no ser adecuado, necesario y proporcional en sentido estricto. A través del estudio fue posible concluir que la criminalización del enriquecimiento ilícito, como está propuesta en las normas internacionales y en las que están en análisis en Brasil, es compatible con el derecho procesal penal brasileño.

PALABRAS-CLAVE: Democracia, Corrupción, Gobernanza, Integridad Públic 


\section{SUMÁRIO}

INTRODUÇÃO

CAPÍTULO I O PROBLEMA DA CORRUPÇÃO NO BRASIL E OS MECANISMOS UTILIZADOS PARA O SEU ENFRENTAMENTO.

1. O PROBLEMA DA CORRUPÇÃO NO BRASIL

1.1. A ESTATURA DA RIQUEZA BRASILEIRA COMO PRIMEIRO FATOR AGRAVANTE DA CORRUPÇÃO NO BRASIL

1.2. O PERCENTUAL PELO QUAL SE MULTIPLICA A CORRUPÇÃO BRASILEIRA COMO SEGUNDO FATOR AGRAVANTE DA CORRUPÇÃO

1.3. A POPULAÇÃO ATINGIDA PELA CORRUPÇÃO NO BRASIL COMO TERCEIRO FATOR QUE AGRAVA O FENÔMENO DA CORRUPÇÃO

2. ANÁLISE HISTÓRICA E CULTURAL DA CORRUPÇÃO NO BRASIL

2.1. A CORRUPÇÃO NO BRASIL PRÉ-COLONIAL E COLONIAL (1500 A 1808)

2.2. A CHEGADA DA FAMÍLIA REAL PORTUGUESA AO BRASIL E A NOVA FASE DA CORRUPÇÃO (1808 A 1822) ...

2.3. A CORRUPÇÃO NO BRASIL INDEPENDENTE. (1822 A 1888)... .51

2.4. CONTEXTUALIZAÇÃO DA CORRUPÇÃO NA FASE MONÁRQUICA DO BRASIL

2.5. CORRUPÇÃO NA PRIMEIRA REPÚBLICA OU REPÚBLICA VELHA (1889 A 1930).

2.6. CORRUPÇÃO NA "ERA VARGAS" (1930 A 1945). .59

2.7. CORRUPÇÃO NA REPÚBLICA POPULISTA (1945 - 1964) 61

2.8. CORRUPÇÃO NO GOVERNO MILITAR (1964 - 1985). .62

2.9. CORRUPÇÃO NA REDEMOCRATIZAÇÃO DURANTE O SÉCULO XX (1985-2000) 68

2.10. CORRUPÇÃO NO SÉCULO XXI (2001-2019). .72

2.11. A CORRUPÇÃO SISTÊMICA OCORRIDA NAS PRIMEIRAS DÉCADAS DO SÉCULO XXI 
2.12. EFEITOS DAS TECNOLOGIAS DO SÉCULO XXI NO MODO DE SE PRATICAR, OCULTAR E COMBATER A CORRUPÇÃO E A NECESSIDADE DE EVOLUIR AS TÉCNICAS DE ENFRENTAMENTO

2.13. CONCLUSÕES SOBRE A ANÁLISE HISTÓRICA DA CORRUPÇÃO NO BRASIL

3. DEFINIÇÃO TÉCNICO-CIENTÍFICA DO CONCEITO DE CORRUPÇÃO NO ORDENAMENTO JURÍDICO BRASILEIRO, CONDUTA QUE SE BUSCA COIBIR COM A CRIMINALIZAÇÃO DO ENRIQUECIMENTO ILÍCITO

3.1. RAÍZES MORFOLÓGICAS E ETIMOLÓGICAS DO TERMO "CORRUPÇÃO"

3.2. DEFINIÇÃO DO CONCEITO DE TÉCNICO-CIENTÍFICO DE "CORRUPÇÃO"

4. A MUDANÇA DE CULTURA COMO FORMA DE COMBATE À CORRUPÇÃO.

5. OS TRATADOS INTERNACIONAIS POR MEIO DOS QUAIS O BRASIL COMPROMETEU-SE A CRIMINALIZAR O ENRIQUECIMENTO ILÍCITO.

5.1. CONVENÇÃO INTERAMERICANA CONTRA A CORRUPÇÃO DA ORGANIZAÇÃO DOS ESTADOS AMERICANOS - OEA.

5.2. CONVENÇÃO DAS NAÇÕES UNIDAS CONTRA A CORRUPÇÃO ...101

6. OS INSTRUMENTOS EXISTENTES DO ORDENAMENTO JURÍDICO BRASILEIRO DESTINADOS À IDENTIFICAÇÃO E PUNIÇÃO DA CORRUPÇÃO.

6.1. O CÓDIGO PENAL E POSTERIORES ALTERAÇÕES .......................103

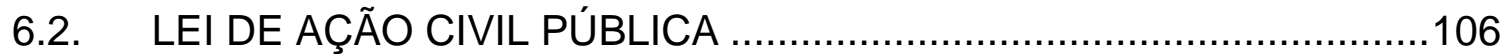

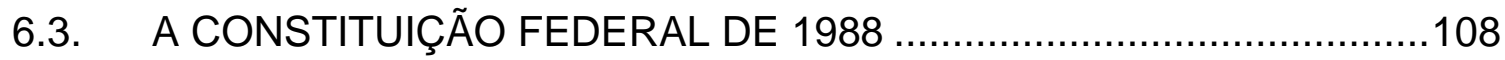

6.4. LEI DOS CRIMES CONTRA A ORDEM TRIBUTÁRIA, ECONÔMICA E CONTRA AS RELAÇÕES DE CONSUMO ……............................109

6.5. LEI DE IMPROBIDADE ADMINISTRATIVA ...................................110

6.6. LEI DE LICITAÇÕES E CONTATOS ADMINISTRATIVOS..................112 
6.7. LEI DE LAVAGEM DE DINHEIRO …….........................................

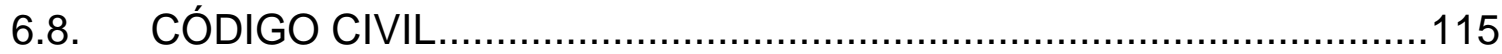

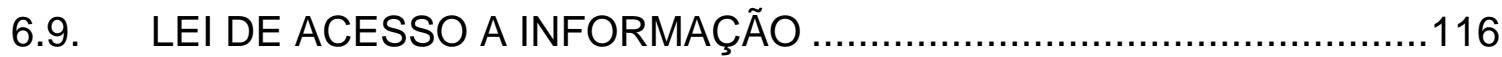

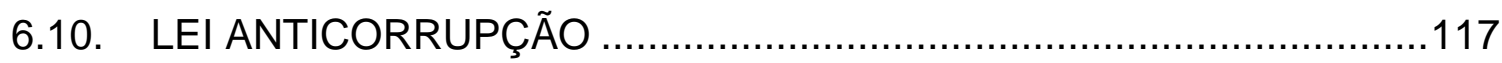

6.11. LEI DAS ORGANIZAÇÕES CRIMINOSAS ....................................118

7. PROPOSTAS ELABORADAS COM O OBJETIVO DE CRIMINALIZAR O ENRIQUECIMENTO ILÍCITO POR PATRIMÔNIO INCONGRUENTE NO BRASIL

7.1. TENTATIVA DO PROJETO DE LEI № 4.850/16 DE CRIMINALIZAR O ENRIQUECIMENTO ILÍCITO - REJEITADA PELO CONGRESSO NACIONAL

7.2. O PROJETO DAS DEZ MEDIDAS CONTRA A CORRUPÇÃO DESFIGURADO

7.3. AS NOVAS MEDIDAS CONTRA A CORRUPÇÃO - EM FASE DE COLETA DE ASSINATURAS.

7.4. A PROPOSTA DE REVISÃO DO CÓDIGO PENAL BRASILEIRO EM TRAMITAÇÃO PERANTE O CONGRESSO NACIONAL

8. O ENFRENTAMENTO DA CORRUPÇÃO PELAS INSTITUIÇÕES JURÍDICAS DESENVOLVIDAS PARA TAL FIM....................................128

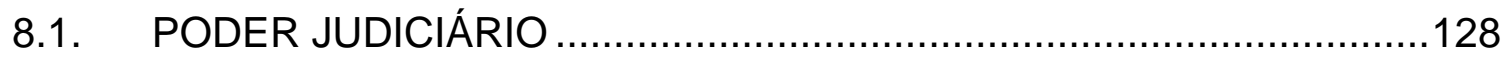

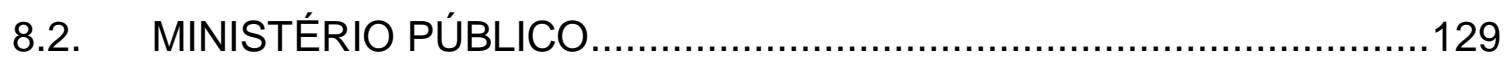

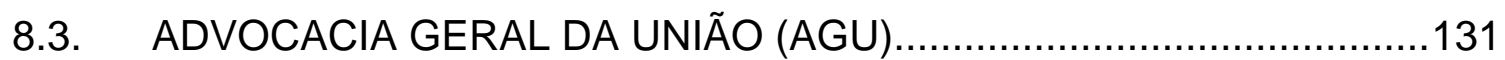

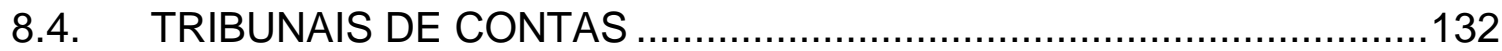

8.5. CONTROLADORIAS DA UNIÃO, DOS ESTADOS E DOS MUNICÍPIOS

8.6. CONSELHO DE CONTROLE DE ATIVIDADES FINANCEIRAS COAF

9. CONCLUSÕES 138

CAPÍTULO II O FATO JURÍDICO “ENRIQUECIMENTO ILÍCITO” 143

1. A NECESSIDADE DE TIPIFICAR O "ENRIQUECIMENTO ILÍCIO" POR PATRIMÔNIO INCONGRUENTE NO DIREITO BRASILEIRO 
2. A TIPIFICAÇÃO DO "ENRIQUECIMENTO ILÍCITO POR PATRIMÔNIO INCOMPATÍVEL COM OS HAVERES" NO ORDENAMENTO JURÍDICO PRÉVIO À ATUAL CONSTITUIÇÃO DA REPÚBLICA DE 1988

3. A DEFINIÇÃO DO CONCEITO DE "ENRIQUECIMENTO ILÍCITO" NO ATUAL ORDENAMENTO JURÍDICO BRASILEIRO

3.1. DEFINIÇÃO DO CONCEITO DE "FUNCIONÁRIO PÚBLICO" NO

DIREITO BRASILEIRO …………………………......................157

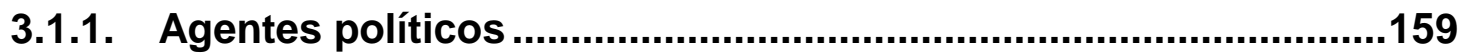

3.1.2. Particulares em colaboração com a administração pública ......163

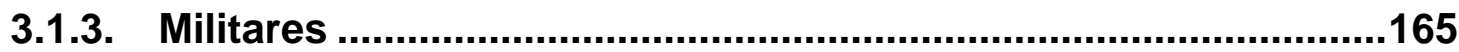

3.1.4. Servidores públicos em sentido estrito......................................167

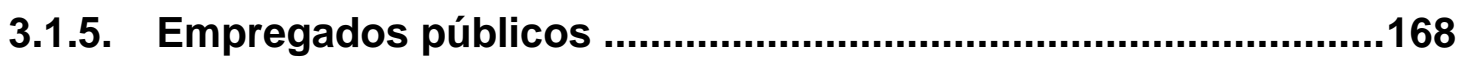

3.1.6. Servidores públicos contratados por tempo determinado ........170

3.1.7. Pessoas politicamente expostas .................................................171

3.1.8. Conclusão acerca do conceito de "servidores públicos" que podem ser autores do fato jurídico "enriquecimento ilícito".....172

3.2. A ATUAL DISCIPLINA DO "ENRIQUECIMENTO ILÍCITO COMO AUFERIÇÃO DE VANTAGEM INDEVIDA" PELO AGENTE PÚBLICO NO DIREITO BRASILEIRO .............................................174

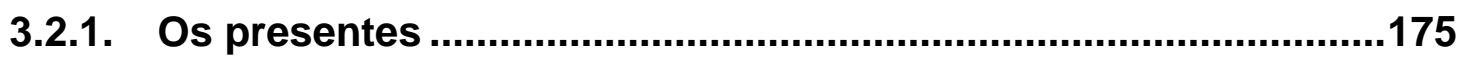

3.2.2. As vantagens indevidas em razão do cargo ocupado................180

3.2.3. O enriquecimento ilícito como ilícito civil tipificado pela Lei de Improbidade Administrativa

3.2.4. $O$ enriquecimento ilícito segundo o regime jurídico específico dos servidores públicos federais brasileiros

3.2.5. $O$ enriquecimento ilícito segundo os tratados internacionais dos quais o Brasil é signatário.

4. A CRIMINALIZAÇÃO DO "ENRIQUECIMENTO ILÍCITO" CONFORME PROPOSTAS EM ANÁLISE NO BRASIL

4.1. A DEFINIÇÃO DO CONCEITO DE "SIGNIFICATIVO" PARA FINS DE AUMENTO OU INCREMENTO DO PATRIMÔNIO CONSIDERADO COMO ENRIQUECIMENTO ILÍCITO 
4.2. A DEFINIÇÃO DO CONCEITO DE "RAZOAVELMENTE JUSTIFICADO" PARA FINS DE APURAÇÃO DO ENRIQUECIMENTO ILÍCITO

4.3. A DEFINIÇÃO DO CONCEITO DE "ENRIQUECIMENTO ILÍCITO" CONFORME AS PROPOSTAS DAS "NOVAS MEDIDAS CONTRA A CORRUPÇÃO"

4.4. A DEFINIÇÃO DO CONCEITO DE "ENRIQUECIMENTO ILÍCITO" CONFORME PROJETO DO NOVO CÓDIGO PENAL BRASILEIRO .201

5. FORMAS DE "ENRIQUECIMENTO ILÍCITO" CONFORME PREVISTO NAS PROPOSTAS EM ANÁLISE

5.1. POSSE DE BENS DE MANEIRA NÃO EVENTUAL COMO FORMA DE ENRIQUECIMENTO ILÍCITO SEGUNDO A PROPOSTA DAS NOVAS MEDIDAS CONTRA A CORRUPÇÃO

5.2. ATOS DE DISPOSIÇÃO DE BENS COMO FORMA DE "ENRIQUECIMENTO ILÍCITO" SEGUNDO A PROPOSTA DAS NOVAS MEDIDAS CONTRA A CORRUPÇÃO. .205

5.3. ATOS DE EXTINÇÃO DE DÍVIDAS COMO FORMA DE "ENRIQUECIMENTO ILÍCITO" SEGUNDO A PROPOSTA DAS NOVAS MEDIDAS CONTRA A CORRUPÇÃO

6. O PROCEDIMENTO DE "PEDIDO DE EXPLICAÇÃO DE PATRIMÔNIO INCOMPATÍVEL" DE QUE TRATA A PROPOSTA DAS NOVAS MEDIDAS CONTRA A CORRUPÇÃO.

7. A EFICÁCIA TEMPORAL DA CRIMINALIZAÇÃO DO ENRIQUECIMENTO ILÍCITO POR PATRIMÔNIO INCONGRUENTE.......210

8. BEM JURÍDICO TUTELADO

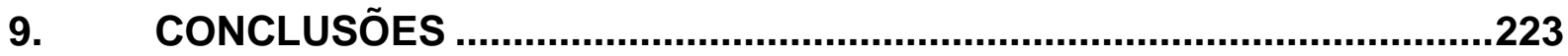

CAPÍTULO III AS NORMAS JURÍDICAS E A PROVA NA FORMAÇÃO DA CERTEZA SOBRE UMA VERDADE ......................................................226

1. A ESTRUTURA LÓGICA DAS NORMAS JURÍDICAS ...........................228

1.1. O PLANO FENOMÊNICO E O PLANO NORMATIVO .......................229 
1.2. NORMAS ÔNTICAS, NORMAS TÉCNICAS E NORMAS DEONTOLÓGICAS

1.3. A DISTINÇÃO ENTRE OS ENUNCIADOS E AS NORMAS, E A SUA RELEVÂNCIA PARA A COMPREENSÃO DAS PROVAS. ..................235

1.4. A ESTRUTURA LÓGICA E OS FUNCTORES DEÔNTICOS ..............238

1.5. SUBSUNÇÃO ENTRE O FATO E A NORMA …...............................242

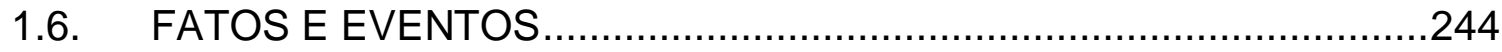

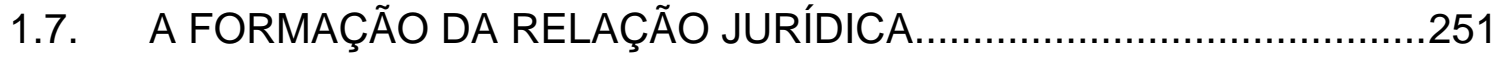

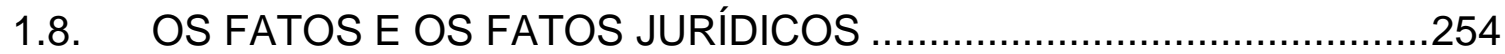

2. A VERDADE, O CONHECIMENTO, A EXISTÊNCIA, A CERTEZA E A DÚVIDA

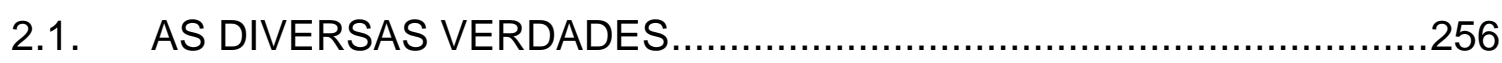

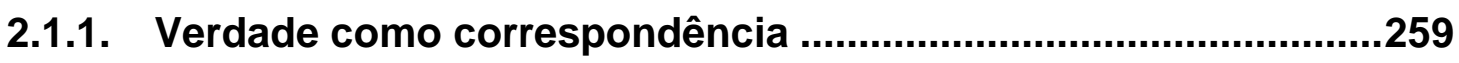

2.1.2. Verdade como coerência..............................................................262

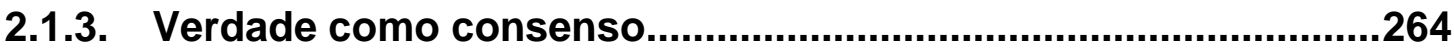

2.2. A DEFINIÇÃO DO CONCEITO DE VERDADE PARA FINS DA

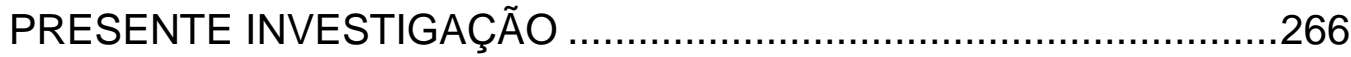

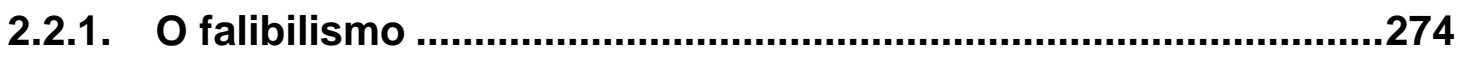

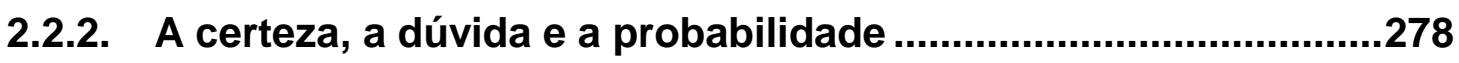

2.3. O STANDARD PROBATÓRIO "CERTEZA ALÉM DE UMA DÚVIDA RAZOÁVEL"

2.3.1. A variação do standard probatório de acordo com a fase processual

2.3.2. A variação da quantidade de convencimento necessária ao atingimento do standard de acordo com as circunstâncias que o crime é praticado

3. CONCLUSÕES 310

CAPÍTULO IV A POSSIBILIDADE JURÍDICA DE QUE O ENRIQUECIMENTO ILÍCITO POSSA SER DEMONSTRADO POR PROVAS INDICIÁRIAS 
1.1. A POLISSEMIA DO SIGNIFICANTE "PROVA" NA LINGUAGEM COMUM E NA LINGUAGEM TÉCNICA DO DIREITO

1.2. DEFINIÇÃO DO CONCEITO DE PROVA PARA FINS DA PRESENTE INVESTIGAÇÃO

1.3. AS PROVAS ENQUANTO PROPOSIÇÕES, ENUNCIADOS OU FATOS JURÍDICOS

2. OS INDÍ́CIOS 335

2.1. OS INDÍCIOS COMO SIGNOS QUE PODEM ESTABELECER A CERTEZA DA VERDADE SOBRE UMA PROPOSIÇÃO.

2.2. CONCURSO, CONCORDÂNCIA E CONVERGÊNCIA DE INDÍCIOS.342

2.3. INDÍCIOS DE PROVAS E PROVAS POR INDÍCIOS

3. A POSSIBILIDADE DE SE ATINGIR A "CERTEZA ALÉM DA DÚVIDA RAZOÁVEL” POR MEIO DE PROVAS INDICIÁRIAS

3.1. AS "TEORIAS CLÁSSICAS" UTILIZADAS PARA DISTINGUIR AS PROVAS DIRETAS DAS PROVAS INDIRETAS

3.2. CRÍTICAS ÀS TEORIAS QUE DISTINGUEM AS PROVAS DIRETAS DAS PROVAS INDIRETAS COM FUNDAMENTO NA NECESSIDADE DE RACIOCÍNIO OU SALTO INFERENCIAL APENAS NO CASO DOS INDÍCIOS

3.3. CRÍTICAS ÀS TEORIAS QUE DISTINGUEM AS PROVAS DIRETAS DAS INDIRETAS SOB O ARGUMENTO DE QUE ESTAS DEMANDARIAM MÚLTIPLOS RACIOCÍNIOS QUE PRODUZIRIAM FRAQUEZA E INFERIORIDADE.

3.4. CRÍTICA À TEORIA QUE ESTEBELECE DISTINÇÃO EM RELAÇAÕ ÀS CONDIÇÕES DA VERDADE.

3.5. PROPOSTA PARA A DIFERENCIAÇÃO DA PROVA DIRETA DA PROVA INDIRETA

3.6. A CAPACIDADE DAS PROVAS DIRETAS GERAREM CERTEZA EM RAZÃO DA PLURALIDADE DE FATOS SOBRE OS QUAIS ELAS SÃO ALICERÇADAS

3.7. A VISÃO CONTEMPORÂNEA DAS PROVAS INDIRETAS.................374

4. CONCLUSÕES 
CAPÍTULO V A COMPATIBILIDADE DA CRIMINALIZAÇÃO DO ENRIQUECIMENTO ILÍCITO COM A PRESUNÇÃO DE INOCÊNCIA E SEUS SUBPRINCÍPIOS

1. ANÁLISE CRÍTICA DAS PRESUNÇÕES NO DIREITO BRASILEIRO .....392

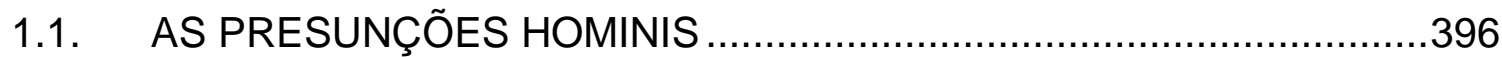

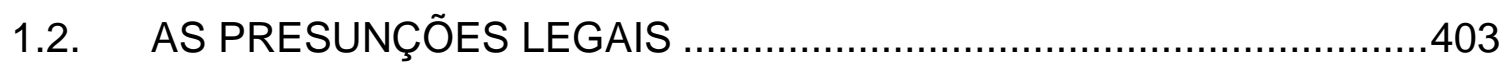

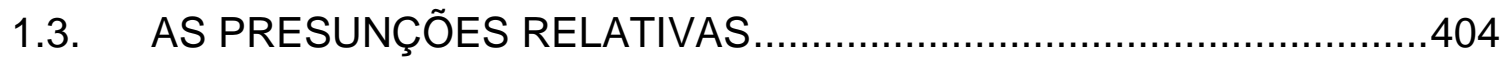

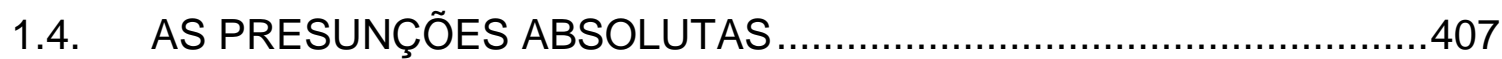

1.5. AS PRESUNÇÕES COM FUNDAMENTO EPISTEMOLÓGICO .........410

1.6. AS PRESUNÇÕES COM FUNDAMENTO AXIOLÓGICO ...................412

2. ANÁLISE DA INFLUÊNCIA DO PRINCÍPIO DA PRESUNÇÃO DE INOCÊNCIA E SEUS SUBPRINCÍPIOS NA CRIMINALIZAÇÃO DO ENRIQUECIMENTO ILÍCITO

2.1. A BUSCA POR UMA DEFINIÇÃO DO CONCEITO CONTEMPORÂNEO DO PRINCÍPIO DA PRESUNÇÃO DE INOCÊNCIA

2.2. O PRINCÍPIO DA PRESUNÇÃO DE INOCÊNCIA DA FORMA QUE É INTERPRETADO NO BRASIL

3. PRINCÍPIOS DECORRENTES DA PRESUNÇÃO DE INOCÊNCIA NO PROCESSO PENAL QUE ESTABELECEM CONFLITO APARENTE COM A CRIMINALIZAÇÃO DO ENRIQUECIMENTO ILÍCITO

3.1. O DIREITO AO SILÊNCIO E A GARANTIA A NÃO AUTOINCRIMINAÇÃO COMO OBSTÁCULOS À CRIMINALIZAÇÃO DO ENRIQUECIMENTO ILÍCITO

3.2. ÔNUS DA PROVA NO PROCESSO PENAL

3.3. O PRINCÍPIO SEGUNDO O QUAL EVENTUAL DÚVIDA QUANTO À CULPA DEVE SER INTERPRETADA A FAVOR DO RÉU, OU "IN DUBIO PRO REO"

3.4. A COMPATIBILIDADE DOS CRIMES DE PERIGO ABSTRATO COM OS PRINCÍPIOS DA LESIVIDADE E DA INTERVENÇÃO MÍNIMA 
4. ANÁLISE DA CONDUTA DENOMINADA "ENRIQUECIMENTO ILÍCITO" COM TODOS OS PRINCÍPIOS QUE DECORREM DA "PRESUNÇÃO DE INOCÊNCIA"

5. ANÁLISE DA CRIMINALIZAÇÃO DO ENRIQUECIMENTO ILÍCITO À LUZ DO POSTULADO NORMATIVO DA RAZOABILIDADE 500

6. CONCLUSÕES 510

CONCLUSÕES .513

RESUMEN EN CASTELLANO .517

REFERÊNCIAS .544 


\section{INTRODUÇÃO}

A presente investigação justifica-se pelo fato de que, como parte de um esforço mundial de combate à corrupção, o Brasil tornou-se signatário e internalizou em seu ordenamento jurídico tratados internacionais por meio dos quais se comprometeu a tratar como crime a conduta consistente em o funcionário público, conceito interpretado em sua mais ampla acepção, auferir enriquecimento ilícito. Em outras palavras, pretende-se tornar ilícita a conduta consistente em o agente público possuir patrimônio incongruente com os seus haveres.

Contudo, as mesmas convenções internacionais estabeleceram a ressalva de que a criminalização do enriquecimento ilícito deveria levar em consideração as limitações jurídicas impostas pelos respectivos ordenamentos jurídicos, o que em outras palavras significa que o compromisso de criminalizar o enriquecimento ilícito deve se conformar à legislação de cada país, o que, diga-se de passagem, é redundante.

Compete, portanto, ao Poder Legislativo, dentro das possibilidades jurídicas do ordenamento jurídico, criminalizar a conduta consistente no agente público possuir patrimônio incongruente. Ainda que ultrapassado o filtro imposto pelo sistema legislativo, eventual desconformidade da nova lei penal em relação aos princípios que regem o sistema processual penal de cada país, as leis incriminadoras são submetidas ao crivo do poder judiciário, a quem compete aferir a sua compatibilidade com as normas a elas hierarquicamente superiores tanto em razão do controle difuso como do controle concentrado de constitucionalidade.

Atualmente já existem duas medidas concretas no sentido de criminalizar o enriquecimento ilícito no Brasil, uma em trâmite perante o Congresso Nacional, especificamente a reforma do Código Penal, e outra, com texto bem semelhante, que está em fase de coleta de assinaturas como parte das Novas Medidas Contra a Corrupção.

Diante deste panorama, o problema que esta investigação de propõe a investigar é se, e de que maneira a criminalização do enriquecimento ilícito 
conforma-se com as normas processuais penais vigentes no Brasil ou, em outras palavras, se a criminalização do enriquecimento ilícito é compatível com os princípios norteadores do processo penal brasileiro.

Como não é possível saber de antemão qual a redação legal que será aprovada pelo parlamento brasileiro, considera-se necessário adotar a seguinte estratégia: Inicialmente será realizada uma análise da estrutura lógica da proposição que se interpretará a partir de praticamente qualquer enunciado que venha a ser redigido no sentido de criminalizar o enriquecimento ilícito, partindo dos textos dos tratados dos quais o Brasil é signatário, da proposta de reforma do Código Penal e das Novas Medidas Contra a Corrupção.

Em seguida será necessário decompor a estrutura lógica da proposição em seus elementos nucleares para, em um próximo passo, identificar estes elementos na estrutura lógica de outras proposições extraídas a partir da exegese dos seus enunciados. Isolados os núcleos das estruturas lógicas e identificados outros semelhantes em outros crimes, será possível investigar como a doutrina e a jurisprudência os tem tratado, o que possibilitará, por meio do raciocínio dedutivo, partindo-se do geral para o individual, presumir como as novas estruturas serão tratadas quando reagrupadas, possibilitando a dedução de como a doutrina e o Poder Judiciário reagirão em relação aos elementos do novo crime.

Também colaborarão com a análise da criminalização do enriquecimento ilícito no Brasil, a análise realizada pela doutrina e pela jurisprudência outros países que já tiveram a mesma experiência, ou mesmo que não tornaram este fato criminoso, para que se possam analisar os motivos para não terem feito.

Pela comparação dos elementos lógicos do crime de enriquecimento ilícito, com os de outros crimes já consagrados no Brasil será possível deduzir quais serão as críticas que eles sofrerão e, somado às censuras já tecidas pelos cientistas que tem investigado este crime, com base no texto dos tratados internacionais dos quais o Brasil é signatário, do Projeto de Reforma do Código Penal e das Novas Medidas Contra a Corrupção, será possível identificar os argumentos, alguns fundados em alegadas violações ao Princípio da Presunção de Inocência, que decorre do Devido Processo Legal, corolário do Estado Democrático de Direito, o de que o crime não 
teria um claro bem jurídico tutelado e, finalmente, o argumento de que violaria o postulado normativo da razoabilidade, composto pelos filtros da adequação, necessidade e proporcionalidade em sentido estrito.

É objetivo da investigação saber como o sistema jurídico processual penal brasileiro interpretaria este novo tipo penal, dando continuidade a uma discussão doutrinária já existente, embora embrionária, acerca dos aspectos processuais penais da criminalização do enriquecimento ilícito no Brasil, tomando-se como base os estudos que já foram realizados sobre o crime de enriquecimento ilícito em outros países, bem como a jurisprudência existente acerca das já referidas estruturas nucleares e atômicas das proposições, colaborando também com futuras investigações sobre o crime de enriquecimento ilícito no Brasil e no mundo.

Também é objetivo da investigação aprofundar e atualizar algumas discussões relevantes ao direito processual penal. Partindo-se da premissa de que as normas jurídicas são fruto da interpretação dos enunciados, e que esta intepretação é realizada levando-se em consideração não apenas uma hermenêutica fria fundada na semântica, mas uma exegese que busca a maximização dos valores positivados na Constituição, em conformidade com o estágio evolutivo da sociedade na qual estar inserida, temas como verdade, prova, presunção de inocência e devido processo legal devem ser constantemente revisitados.

Objetiva-se também colaborar com o Poder Legislativo no que diz respeito ao aprimoramento dos enunciados normativos que estão sendo formulados com 0 objetivo de criminalizar a conduta, bem como o Poder Judiciário, especialmente quanto à interpretação das normas que propõem a criminalização desta conduta.

Diante do problema circunscrito, descortinam-se três hipóteses. A primeira hipótese é a de que a criminalização do enriquecimento ilícito é incompatível com o ordenamento jurídico brasileiro por violar os princípios que o norteiam. A segunda hipótese é de que o crime de enriquecimento ilícito é compatível com o sistema processual penal brasileiro sem quaisquer ressalvas. A terceira hipótese, por sua vez, é a de que o crime de enriquecimento ilícito somente seria compatível com os princípios que regem o processo penal brasileiro se alguns dos enunciados 
normativos fossem interpretados conforme de alguma determinada maneira, o que poderá ser declarado pelo Poder Judiciário, naquilo que se conhece como "interpretação conforme a Constituição".

A investigação foi dividida em cinco capítulos que podem ser sintetizados da seguinte forma:

O objetivo do Capítulo I é aferir se a corrupção é um problema real e relevante para o Brasil, pois se assim não for inexiste justificativa para envidar esforços para estabelecer mais um mecanismo para o seu enfrentamento, tornando a edição de qualquer norma desnecessária neste sentido. Para tanto será realizado um estudo acerca da evolução da corrupção nos mais de cinco séculos de história brasileira, com o objetivo de investigar desde quando este problema existe como está arraigado na cultura brasileira, bem como se apresenta viés de melhora ou de piora, e qual é o grau dos prejuízos que acarreta ao país.

Para responder a esta pergunta será necessário aferir se a corrupção praticada por agentes públicos é ou não um problema que atinge o Brasil, de que maneira e de que intensidade ele o faz, assim como quais são os meios atualmente empregados para combatê-la, e se eles estão mostrando-se suficientes. Identificado o impacto financeiro será possível comparar os dados orçamentários brasileiros com os números relativos aos problemas sociais para apurar se e em que medida os valores desviados poderiam influenciar no desenvolvimento social da nação.

Tratando-se de uma investigação sobre uma nova técnica que se pretende estabelecer no Brasil com o objetivo de combater a corrupção, também se mostra necessário adentrar na definição do conceito de corrupção, para o que será imprescindível buscar elementos no ordenamento jurídico interno, especialmente nos tratados que o Brasil é signatário, nas outras convenções internacionais, na doutrina e na jurisprudência.

Esta análise também será relevante para identificar e categorizar quais são os meios atualmente empregados para combater a corrupção no Brasil, jurídicos ou não. Também será importante destacar o papel de cada um dos principais órgãos que tem por objetivo, direta ou indiretamente, combater a corrupção. 
Ainda no que diz respeito às medidas que ainda estão em andamento para combater a corrupção no Brasil merece destaque o projeto das Dez Medidas Contra a Corrupção, que foi rejeitado pelo Congresso, mas seus ideais continuam existentes de outras formas, as Novas Medidas Contra a Corrupção, bem como o projeto de revisão do Código Penal, que tem como um dos crimes o enriquecimento ilícito.

O Capítulo II será dedicado ao estudo das proposições que se extraem dos enunciados por meio dos quais se pretende criminalizar o enriquecimento ilícito, mesmo sem ainda existir uma norma penal específica, mas que se pretende induzir pelos projetos que se encontram em estudos, pelas experiências de outros países e pelo texto dos já mencionados tratados dos quais o Brasil é signatário. Neste Capítulo que serão decompostos os diversos elementos que poderão e deverão integrar o tipo penal enriquecimento ilícito, especificamente no que diz respeito à forma com que foram tratados pela doutrina e pela jurisprudência.

Incialmente há a necessidade de evidenciar como o ordenamento jurídico brasileiro já havia definido o conceito de enriquecimento ilícito antes da atual constituição, promulgada em 1988, para identificar a forma com que foi tratada e interpretada neste período e, embora as conclusões não devam ser as mesmas, pois houve uma radical mudança nos valores que nortearam o ordenamento jurídico, alguns conceitos podem ser aproveitados como pontos de partida e paradigmas para a presente discussão.

Também é objeto do Capítulo II a análise da quantificação do que poderia significar um patrimônio incompatível, com o objetivo de afastar diferenças patrimoniais que não significam uma verdadeira alteração substancial no patrimônio a ponto de ser indício de uma prática ilícita. Para isso será necessário aferir como o direito brasileiro tem interpretado a aceitação do princípio da bagatela aos crimes que envolvem a probidade da administração pública. Tudo isso surge porque existe um entendimento segundo o qual são atípicas as condutas de baixíssima lesividade, que não maculam o bem jurídico tutelado, como o furto de uma barra de chocolate. A questão que surge é se este entendimento também seria aplicável aos crimes praticados pelo agente público contra a administração pública, nos quais o bem tutelado não pode ser expresso em dinheiro, pois estes atos atingiram a moralidade 
da administração pública independente do valor. Desta forma haverá a necessidade de aferir se o princípio da bagatela seria aplicável ao crime de enriquecimento ilícito.

Diante da já mencionada criatividade em se simular (fazer parecer outra coisa) ou dissimular (fazer desaparecer), o enriquecimento ilícito, as propostas legislativas brasileiras tentaram imaginar todos os indícios de enriquecimento ilícito, a fim de fazê-los constar no tipo penal, e que devem ser analisados nesta investigação.

Neste sentido será analisada a conduta consistente na posse não eventual de bens, fato de difícil comprovação e que somente pode ser realizada por meio de provas indiretas. Assim, é necessário investigar se o agente público tem o direito ao "uso não eventual", termo de difícil exegese, de "bens incompatíveis com o seu patrimônio", outro termo de complicada interpretação, que geralmente é franqueado por um empresário como forma de, no mínimo, angariar a simpatia de um agente público em prol dos seus interesses, como o empréstimo de uma casa de praia. Todavia a posse não eventual pode ser também uma forma disfarçada de pagamento de propina quando o agente recebe o bem para si, para uso ilimitado, uma verdadeira transferência informal de patrimônio registrada em uma conta de propina, embora a transferência oficial seja relegada a outro momento, com uma espécie de título ao portador. Como já mencionado a comprovação desta conduta é muito difícil, envolve conceitos de difícil interpretação e depende exclusivamente de provas indiretas.

Diante da dificuldade de se provar o ato de corrupção, o que quando ocorre, raramente é compreensível, por meio das provas diretas, surge à necessidade de se punir a sua decorrência lógica, qual seja o enriquecimento ilícito. A exemplo do furto, que também se pune o ato e a receptação, na corrupção criminaliza-se também o enriquecimento ilícito, admitindo-se como tal o ato de um agente público possuir e vender um patrimônio de origem injustificada. Definitivamente isto não impede a prática da corrução, mas a torna menos proveitosa, o que não deixa de ser um fator de inibição.

Os projetos em análise no Brasil também buscam tratar como enriquecimento ilícito o fato de alguém extinguir uma dívida de um agente público, o que pode 
ocorrer em relação a bens que devem ser registrados, como prestações de automóveis, embora isto seja muito óbvio para os mecanismos de controle, mas na prática também acontece em relação a faturas de cartões de crédito, despesas com mensalidades escolares de filhos, condomínio, dentre outros tipos de vantagens indevidas que se pode oferecer a um agente público, e que serão tratadas como enriquecimento ilícito.

Finalmente, será conferida especial atenção ao que se denomina por "bem jurídico tutelado", eis que contundentes críticas tecidas contra a criminalização do enriquecimento ilícito foram estabelecidas no sentido de que este seria um crime sem um bem jurídico tutelado muito bem delineado, e isto comprometeria toda a sua validade jurídica.

No Capítulo III serão lançados os primeiros alicerces teóricos necessários à compreensão do que se entende por prova indiciária, uma vez que, como já mencionado, dificilmente a corrupção e o enriquecimento ilícito serão comprovados por uma prova direta, surgindo a necessidade de demonstrar os fatos típicos pela prova indiciária, que por sua vez ainda é tratada por parte da comunidade científica como uma prova inferior, mais fraca que a prova direta e, acima de tudo insusceptível de gerar uma condenação penal.

Para compreender a diferença entre a prova indiciária e a prova direta será necessário adentrar na estrutura lógica da norma jurídica e compreender a função do fato na subsunção com a hipótese, conjunção imprescindível para a implicação da consequência jurídica. Para tanto será aprofundado o estudo sobre as normas jurídicas, assim tratadas como produto da atividade do intérprete realizada a partir não apenas dos enunciados normativos imediatos, mas de uma atividade exegética que deve levar em consideração os valores e os princípios que regem o sistema jurídico e que constituem o objetivo final do direito. Neste momento deverá haver uma diferenciação entre as normas, institutos dinâmicos que acompanham o desenvolvimento da comunidade na qual estão inseridas e os enunciados estáticos, a partir dos quais elas são interpretadas.

O estudo deverá continuar até ingressar na estrutura mínima, qual seja a dos functores ou modais deônticos, ponto a partir do qual se torna nítida a função da 
prova no estabelecimento do fato, muito embora daí decorra outro problema, pois, sendo o fato algo apresentado com o objetivo de estabelecer a verdade de uma proposição hipotética apresentada por uma parte, será necessário definir o conceito de verdade válido no discurso jurídico, ou melhor, quais conceitos de verdade são válidos no discurso jurídico.

Neste momento será preciso penetrar ainda mais na filosofia do direito para estabelecer o que vem a ser o conhecimento e a existência, caminho obrigatório para chegar à verdade como correspondência, verdade como coerência e a verdade como consenso, pois atingi-las ou declará-las é o objetivo final de toda a teoria que se constrói sobre provas, atividade probatória, provas diretas e provas indiretas, especialmente, no presente caso, se as provas indiretas podem estabelecer a verdade acerca de uma proposição que venha a culminar na condenação penal de uma pessoa.

Conhecidas as limitações das teorias sobre a verdade e as fragilidades das teorias sobre a realidade, para indagar acerca da possiblidade do intérprete saber que alcançou a verdade ou, em outras palavras, afirmar sobre a certeza sobre uma verdade, especialmente a verdade como correspondência, e se a certeza da verdade como correspondência é requisito necessário a uma condenação penal. Diante destas dúvidas apresentadas, surge a necessidade de se analisar a teoria dos standards probatórios, especialmente o da certeza além de uma dúvida razoável, e como ela é tratada no direito brasileiro. Acerca deste ponto, surge a indagação de se o standard probatório pode ser alterado de acordo com a fase processual e se o grau de certeza necessário para preencher um determinado standard pode ser alterado de acordo com o tipo de crime investigado e com a forma com que ele é praticado.

No Capítulo IV terá início uma análise do tipo penal hipotético do enriquecimento ilícito com as normas que regem a produção de provas no direito brasileiro, especialmente as provas indiciárias, ainda tratadas por alguns como prova de menor peso e menor força probatória em relação às provas diretas, até insuficientes para uma condenação penal, afirmativa que será apreciada conforme as mais modernas teorias doutrinárias e processuais. 
Com o objetivo de realizar a análise da teoria das provas no direito brasileiro será imprescindível adentrar na complexa polissemia do termo prova, para que seja indagada a sua natureza relacional, e então evidenciar a sua verdadeira função na criação do fato jurídico, que se difere do evento ou do acontecimento, e é exatamente o elemento que se subsome à hipótese normativa estabelecendo a implicação da consequência jurídica prevista na norma.

Demonstrada a lógica da constituição dos fatos, da produção das provas, do estabelecimento da verdade e da certeza, bem como do standard probatório necessário a ensejar uma condenação, será preciso tratar dos indícios a fim de indagar se eles e as provas neles alicerçadas, ditas provas indiciárias, ou provas indiretas, são suficientes, ou não, para o estabelecimento da certeza além da dúvida razoável, o que sinteticamente significa questionar se uma condenação pode ser exclusivamente fundamentada em uma prova indireta, que no caso do hipotético crime de enriquecimento pode vir a ser a única prova possível de ser produzida, sendo que a sua eventual não aceitação poderá significar um verdadeiro "salvo conduto" para que os corruptos, especialmente os integrantes de organizações criminosas, possam praticar seus atos na perfeita paz, com a segurança de que 0 sistema processual penal brasileiro não é eficiente para prender ricos e poderosos.

Tendo tratado das provas por indícios, ou provas indiciárias, será necessário definir o seu conceito, lançando um olhar crítico sobre as teorias que ainda preconizam que ela seria uma prova "menor" ou mais fraca, especialmente quando comparada às provas diretas como, por exemplo, a fundamentada na inexistência do salto inferencial, a balizada na premissa de que a prova direta seria uma mera aplicação do direito, e a teoria segundo a qual a prova indireta residiria numa mera analise probabilística, enquanto na direta haveria a certeza.

Todavia, a análise das teorias que impõem uma fraqueza às provas indiretas eventualmente poderá servir para reforçar a sua capacidade para estabelecer uma certeza e, eventualmente, demonstrar que poderão ser ainda mais seguras que as provas diretas.

Investigada a primeira objeção à criminalização do enriquecimento ilícito no Brasil, sob o fundamento de que neste caso a condenação necessariamente seria 
fundamentada em provas indiciárias, e que estas não teriam força ou peso necessário a uma condenação penal, pois não seriam suficientes para se chegar à verdade ou à certeza absoluta, é necessário adentrar nas outras objeções.

Enquanto os Capítulos III e IV analisam a sistemática de produção de provas vigente no processo penal brasileiro, especialmente no que diz respeito à possibilidade de se condenar alguém com fundamentos em fatos provados por provas indiciárias, o Capítulo $\mathrm{V}$ aborda a consonância da criminalização do enriquecimento ilícito em relação aos princípios processuais penais brasileiros que se relacionam com o devido processo legal, iniciando-se pelo princípio da presunção de inocência, tarefa para a qual será necessário adentrar na teoria geral das presunções.

Diante da gravidade dos argumentos lançados contra a criminalização do enriquecimento ilícito, bem como da estatura dos princípios que indubitavelmente colidem com a nobre pretensão de reduzir a corrupção no Brasil, mas sem adentrar no utilitarismo, será necessário analisar cada um dos raciocínios. Assim será imprescindível conhecer a distinção entre as presunções hominis e as presunções jurídicas para, por sua vez, estabelecer a diferença entre as presunções relativas e absolutas, distinguindo-as das ficções para, finalmente, estudar as presunções jurídicas com fundamento axiológico das presunções jurídicas com fundamento epistemológico, pois esta diferença será fundamental para a compreensão do verdadeiro sentido e alcance da presunção de inocência, bem com do que é necessário para ilidi-la.

Neste aspecto merece destaque a análise da corrente de pensamento que milita a favor de uma maior rigidez da presunção de inocência e que, portanto, demandaria um standard probatório mais elevado para que fosse ilidida. De outro lado encontram-se aqueles que defendem uma maior relatividade da presunção de inocência, ou seja, a redução do standard probatório necessário para ela possa ser refutada. Tratando-se de uma questão de rigidez de standard probatório, será necessário conhecer os argumentos de cada linha de pensamento e a identificação de "casos pilotos" ou leading cases, para que seja possível aferir qual é a intepretação conferida pelo Supremo Tribunal Federal acerca das provas necessárias a refutar a presunção de inocência. 
Outro princípio decorrente do devido processo legal que, juntamente com a presunção de inocência, pode gerar controvérsia em relação à compatibilidade da criminalização do enriquecimento ilícito com o sistema processual penal brasileiro é o direito ao silêncio e a garantia de não produzir prova contra si próprio, pelo qual o acusado possui a faculdade de não tecer qualquer manifestação acerca dos fatos que a ele são imputados, sem que acerca deste silêncio possa ser presumida qualquer espécie de culpa.

No caso do crime de enriquecimento ilícito a primeira dúvida que surge é se, negando-se $o$ acusado a explicar a origem do patrimônio manifestamente incompatível com os seus haveres licitamente justificáveis, e sendo o ônus da acusação realizar a prova do ilícito, se o silêncio do acusado poderia ser interpretado de forma a prejudica-lo. $O$ argumento favorável à incriminação é no sentido de que nestes casos ao acusado é desproporcionalmente mais fácil produzir a prova, se comparado à acusação, podendo-se até estabelecer a "presunção hominis" no sentido de que se o acusado não quer demonstrar a origem do patrimônio, é porque ele foi obtido ilicitamente. Este argumento torna-se ainda mais contundente se for levado em consideração que a prova não é das partes, mas sim do juiz, que poderia, fundamentadamente, flexibilizar a distribuição dos ônus da sua produção, para atribuir-Ihe àquele que, no caso concreto, possui mais capacidade para produzi-la. Contudo, esta possibilidade de inversão do ônus da prova é limitada pelo direito ao silêncio e pelo direito a não produção de prova contra si próprio.

A partir daí também surge a necessidade de se aferir se estes direitos, enquanto estabelecidos por princípios, são absolutos ou podem ser relativizados em casos concretos, a depender dos bens jurídicos que estiverem em questão, cedendo espaço para outros princípios, como da mínima eficácia da Lei penal e até os direitos fundamentais das milhões de "próximas vítimas" que a corrupção atingirá.

Também como decorrência do que se entende por devido processo legal, outra questão que será analisada é se a criminalização do enriquecimento ilícito deve levar em consideração o direito do acusado ao benefício da dúvida, ou seja, que não tendo sido a acusação competente para estabelecer a origem ilícita do patrimônio do acusado, nem o acusado se manifestando acerca da origem do 
patrimônio, seja declarado o estado de dúvida razoável que beneficia o réu, segundo a máxima in dubio pro reu.

Ainda neste momento serão analisados os principais julgamentos proferidos nas últimas décadas pelo Supremo Tribunal Federal, nos casos em que ele apreciou o conflito entre a presunção e inocência e o interesse do Estado em punir os criminosos, especialmente as decisões que envolvem a prática de corrupção, que merecem tratamento especial em decorrência da gravidade dos danos causados e da dificuldade na produção de provas diretas.

Tratando-se de enriquecimento ilícito é possível imaginar a hipótese de o acusado afirmar que a revelação da origem do patrimônio desproporcional aos seus haveres poderia comprometer o seu direito a intimidade como, por exemplo, no caso de haverem sido auferidos de maneira que considera imoral ou infamante. Neste caso será analisado o conflito entre o interesse público em combater a corrupção e a intimidade do acusado.

Há, portanto, necessidade do cotejamento dos princípios jurídicos que envolvem a criminalização do enriquecimento ilícito, especialmente os ligados ao ônus probatório, presunção de inocência e à força das provas, especialmente as indiretas, e os princípios ligados ao devido processo legal, como o direito ao silencio, o direito a não produzir prova contra si próprio, e até o direito à intimidade. Todos eles devem ser sopesados com o interesse jurídico de enfrentar aquele que pode ser considerado o maior mal que aflige o Brasil.

A criminalização do enriquecimento ilícito, apesar de ser um instrumento de luta contra a corrupção, recebe críticas de correntes da comunidade científica que sobrepesa os direitos individuais dos acusados em detrimento do interesse do Estado de inibir a corrupção. Desta maneira, amesquinha os direitos individuais das vítimas da corrupção que, em tese, são praticamente todos os demais brasileiros que, de uma forma ou outra, sofrem os efeitos de viverem no país que protagoniza os grandes casos de corrupção do mundo, e onde ela é mais percebida.

Esta análise não é simples e uma visão precipitada do problema poderia conduzir a uma conclusão meramente utilitarista, segundo a qual os fins justificam 
os meios, a partir da qual seria possível, em prol da maximização de um bem jurídico, liquidar direitos fundamentais.

Serão analisados ainda como outros países com sistema jurídico semelhante ao brasileiro trataram do conflito jurídico estabelecido entre a criminalização do enriquecimento ilícito e alguns dos direitos individuais, sem aprofundar demasiadamente o estudo, pois extrapolaria os limites epistemológicos e físicos da investigação.

Isto porque pela discussão acerca da legalidade e da constitucionalidade de um tipo penal que ainda não existe no Brasil, embora integre o ordenamento jurídico de outros países com sistema legal semelhante, será possível saber, de antemão, com relativa margem de erro, como será o entendimento do Supremo Tribunal Federal sobre o enunciado que no Brasil somente há nos projetos de lei e nos tratados internacionais dos quais é signatário.

Todavia, considerando-se que os conceitos utilizados para a instituição do novo tipo penal estão inseridos no texto constitucional desde sua origem, será possível traçar uma linha de tendência de qual será a interpretação conferida a eles, bem como especular acerca de qual será o resultado obtido a partir da colisão das regras e da ponderação dos princípios constitucionais envolvidos, especialmente quando direitos e garantias fundamentais do acusado conflitam com o interesse punitivo do Estado de busca punir criminosos e assim evitar a prática de outros crimes.

Sendo a razoabilidade um postulado normativo largamente aceito no direito brasileiro, seja pela doutrina, pela jurisprudência, e ainda de forma tímida pela legislação, existe a necessidade de se analisar a criminalização do enriquecimento ilícito pela ótica do tríplice filtro da adequação, necessidade e proporcionalidade em sentido estrito. Talvez o teste mais difícil da razoabilidade de uma norma punitiva seja exatamente o da proporcionalidade em sentido estrito, pelo qual é realizada a ponderação se os bens jurídicos atingidos pela medida limitativa de direitos são proporcionais aos bens jurídicos maximizados com a medida.

Para este cálculo devem-se levar em conta quais são os bens jurídicos ameaçados ou violados com a medida e quais são aqueles que, por outro lado, são 
por ela protegidos. A partir do rígido recorte epistemológico conferido a esta investigação foi deliberadamente dela excluída a análise das teorias, da história e da sociologia que envolve a corrupção.

As normas éticas e deontológicas em vigor recomendam parcimônia ao tratar de processos em andamento, razão pela qual seria preferível utilizar apenas aqueles transitados em julgado. Todavia, como perante o poder judiciário brasileiro há processos que tramitam há mais de um século, omitir os processos em andamento empobreceria a investigação. Assim, foram tratados dos processos pendentes, preferencialmente em notícias veiculadas pela imprensa e em peças processuais públicas, obtidas nos sítios eletrônicos do Poder Judiciário, sem que isto implique juízo de valor acerca da autoria e da materialidade. 


\section{CONCLUSÕES}

A partir dos estudos desenvolvidos para a concretização da presente investigação foi possível estabelecer algumas conclusões que passam a ser expostas, sinteticamente, em quinze pontos.

1 - A corrupção é uma mazela que aflige o Brasil há séculos e atualmente é possível relaciona-la aos maiores problemas que afligem o Brasil, sendo que os meios até então empregados para combate-la mostram-se ineficientes, de onde decorre a necessidade de se buscar novas formas de enfrentamento, dentre os quais merece destaque a criminalização do enriquecimento ilícito. O problema que esta investigação busca solucionar é exatamente se este novo crime é ou não compatível com o sistema processual penal brasileiro.

2 - A criminalização do enriquecimento ilícito não viola o princípio da necessidade da intervenção penal mínima na liberdade individual, ultima ratio ou o principio da extraordinariedade da norma penal, pois este crime tenta inibir a corrupção, tornando-a menos atrativa, buscando obter um êxito que não foi atingido por outros institutos.

3 - O Brasil tem lançado mão de diversos mecanismos para combater a corrupção, desde medidas educativas até a criminalização de condutas que se denominam por "práticas corruptas", passando pela criação de órgãos, leis e sistemas especialmente dedicados ao combate à corrupção, e todos tem se mostrado relativamente ineficientes, pois os corruptos parecem contornar as medidas desenvolvendo novas formas de delitos, muitas vezes aproveitando-se de novidades tecnológicas, especialmente tratando-se de crimes do colarinho branco.

4 - Os bens jurídicos tutelados pela criminalização do enriquecimento ilícito são a incolumidade do ordenamento jurídico, a probidade administrativa, a moralidade e a transparência da administração pública, bem como a confiança que o cidadão deve manter em relação aos agentes públicos.

5 - Trata-se de um crime próprio, ou seja, que somente pode ser praticado por uma categoria de pessoas, no caso do Brasil os "agentes públicos", gênero que abarca todos aqueles que, de forma geral, agem pela Administração Pública, um conceito complexo que foi elaborado para que não restassem dúvidas acerca da sua amplitude semântica. Todavia como as mencionadas convenções internacionais utilizam o termo "funcionários públicos", concluiu-se que existe a necessidade de 
que, no Brasil, o termo venha a ser substituído por "agente público", a exemplo do que já acontece nas demais normas, merecendo destaque a Lei de Improbidade Administrativa.

6 - Apesar dos termos "enriquecimento ilícito" e "enriquecimento indevido" poderem significar um grande leque de condutas, o "enriquecimento ilícito" de que trata a presente investigação consiste no fato do agente público manifestar patrimônio incongruente, ou seja, o patrimônio que possui, ostenta ou vende é incompatível com o que periódica e obrigatoriamente declara ou pode declarar à Administração Pública.

7 - O fato do enriquecimento ilícito eventualmente vir a ser comprovado por meio de provas indiciárias não é obstáculo real à sua criminalização, eis que na atualidade não é mais possível atribuir a elas qualquer relação de fraqueza, inferioridade ou insegurança em relação às provas diretas, muito menos afirmar que representam qualquer risco à segurança das decisões judiciais, o que justifica pelo fato de que elas, prima facie, não conduzem a um grau menor de certeza da verdade sobre algo, o que restou comprovado pelo estudo da teoria geral da norma jurídica, da função da prova, dos conhecimentos sobre a verdade, a certeza e os standards probatórios adotados no direito processual penal brasileiro, especialmente o da certeza além de uma dúvida razoável.

8 - A criminalização do enriquecimento ilícito não viola os princípios decorrentes da presunção de inocência, de fundamento axiológico, eis que sendo relativa admite prova em contrário, no caso permitindo que o acusado demonstre a licitude do patrimônio.

9 - A criminalização do enriquecimento ilícito não viola o direito ao silêncio do acusado, nem a garantia à não autoincriminação, muito menos ao princípio nemo tenetur se detergere pois a proposição "patrimônio não justificável" não é uma condição do tipo, como se o acusado fosse chamado a justificar a origem do patrimônio e seria considerado crime apenas se não fosse capaz de faze-lo. Muito pelo contrário, o termo "patrimônio que não se possa justificar" é o patrimônio ostensivo incompatível com o patrimônio oficialmente declarado do agente público, cuja diferença é presumida ilícita, em uma presunção legal relativa que pode ser ilidida pelo acusado no que se denomina por "justificação" do patrimônio, da mesma forma que ocorre com todo e qualquer um dos diversos crimes que possuem uma presunção em sua estrutura lógica. 
10 - A eventual necessidade do agente público declinar a origem do patrimônio incongruente não viola a intimidade do acusado, pois tratando-se de questões patrimoniais e ligadas à intimidade do acusado, é possível tratar o processo em sigilo, em sistemática que não difere da que ocorre em qualquer outro crime.

11 - A criminalização do enriquecimento ilícito não atenta contra a distribuição dos ônus da prova no processo penal, pois é ônus da acusação demonstrar a certeza além de uma dúvida razoável de que o acusado possui patrimônio ostensivo incongruente com o seu patrimônio declarado, embora permitindo que o acusado ilida tal presunção demonstrando a legalidade do patrimônio e desconstituindo esta certeza para gerar a dúvida absolvitória. Em todo caso, recai sobre a acusação o ônus de demonstrar e provar a incongruência do patrimônio, baseado nas informações que a lei obriga ao agente público prestar à administração.

12 - A criminalização do enriquecimento ilícito é compatível com o princípio segundo o qual no processo penal a dúvida pende a favor do acusado, naquilo que se denomina por benefício da dúvida ou "in dubio pro reo", que efetivamente vigora no direito penal, processual penal, e deve ser aplicado por ocasião do julgamento do processo e não quando da produção das provas. Concluiu-se que a invocação do "in dubio pro reo" decorre do raciocínio segundo o qual se a acusação não pode obrigar o acusado a declarar a origem lícita do patrimônio, e se podem existir infinitas origens lícitas para ele, deveria ser aplicado o benefício da dúvida para absolver o acusado. Este raciocínio, da mesma forma que os já expostos, parte da equivocada premissa de que a justificação da parte faria parte do tipo, quando na verdade o fato típico ocorre com a constatação da diferença entre o patrimônio ostensivo e o patrimônio declarado, e a justificação é uma excludente de ilicitude. Tratando-se da dúvida, concluiu-se que ela existe em toda e qualquer decisão que leve em consideração a verdade como correspondência, e o que o direito veda é que alguém seja condenado quando exista uma dúvida razoável acerca da autoria e materialidade do crime, pois a condenação demanda uma "certeza além de uma dúvida razoável". Haverá dúvida, e esta deverá ser tratada favoravelmente ao acusado, no momento da análise da probabilidade da certeza das alegações acerca da licitude do patrimônio, aliás, da mesma forma que há com todo e qualquer crime.

13 - A criminalização do enriquecimento ilícito é um crime de perigo abstrato, pois a partir de uma determinada conduta presume-se a mácula ao bem jurídico tutelado independente de qualquer ulterior demonstração de um dano concreto. Tais crimes são permitidos pelo ordenamento jurídico brasileiro, havendo diversos deles 
em vigor, sem que as cortes responsáveis pelo controle das leis tenha se manifestado contra eles.

14 - A criminalização do enriquecimento ilícito passa pelos crivo imposto pelo postulado normativo da razoabilidade, que tem como subprincípios a adequação, a necessidade a proporcionalidade em sentido estrito.

15 - finalmente, a criminalização do enriquecimento ilícito, da forma que se pretende instituir pelos diplomas que se encontram em análise, não macula quaisquer dos princípios que norteiam o processo penal brasileiro, confirmando-se a hipótese inicialmente proposta no sentido de que não haveria violação, especialmente pelo fato de que o fato jurídico em exame é a diferença substancial entre o patrimônio ostensivo e o patrimônio oficialmente declarado pelo agente público, presumidamente atentatório aos bens jurídicos tutelados, em especial a moralidade da administração pública. A todo momento é permitido que 0 agente público ilida a referida presunção de ilicitude do patrimônio incongruente, demonstrando que o patrimônio foi adquirido por meios lícitos, sendo que em relação a este argumento eventuais dúvidas deverão ser interpretadas a favor do acusado, e qualquer condenação somente poderá ser realizada diante de uma certeza além de uma duvida razoável. 


\section{RESUMEN EN CASTELLANO}

Esta investigación nació de la indignación de quien vive en un país continental, una de las mayores potencias económicas, agrícolas e industriales del mundo, pero cuyas calles hay gente comiendo basura, cuando la encuentran. Una nación que tiene tecnología para poner cohetes en el espacio pero no puede evitar que enfermedades curables sigan matando a los brasileños más pobres, en un país marcado por el abismo social, donde hay municipios con tasas de desarrollo humano comparables a los países europeos, y otros semejantes a los peores lugares del mundo. Casi todos estos males podrían erradicarse o controlarse mediante algunas medidas, incluida la reducción de la corrupción, un mal devastador que quita lo esencial de los más pobres para aumentar el patrimonio superfluo de los más ricos, siempre de manera injusta, disfrazada y mortal.

Como si no fuera suficiente saber que una parte importante del erario está drenado por la corrupción, la ineficiencia y la malversación de dinero público, el contribuyente brasileño todavía está condenado a ver al corrupto yendo a los mismos lugares que él y disfrutando impunemente del producto de su crimen. Esto se debe a que los delincuentes de cuello blanco bien asesorados saben cómo utilizar las lagunas en el sistema legal para postergar el proceso y prácticamente nunca son castigados por corrupción, lo que garantiza el uso y la propiedad de activos absolutamente incompatibles con sus posesiones, siendo esto perfectamente legal y sin que esto constituya ninguna infracción penal. Es solo un ejemplo de cómo el sistema penal brasileño, tan severo con los crímenes practicados por los pobres, es excesivamente benevolente con los crímenes practicados por los ricos y poderosos.

En los primeros años del siglo XXI Brasil firmó importantes tratados internacionales que recomendaron a los signatarios, como una forma de ayudar en la lucha contra la corrupción, la criminalización del enriquecimiento ilícito, porque de esta manera se establecería otro obstáculo al crimen, reduciendo la ventaja de un delito generalmente practicado a través del análisis de costo-beneficio; pero dicha penalización debe llevarse a cabo dentro de los límites de las normas procesales penales que guían a cada uno de los sistemas legales. 
A partir de este escenario, el objetivo de la presente investigación es determinar si la conducta generalmente llamada enriquecimiento ilícito del agente público sería compatible con las normas que nortean el sistema procesal penal brasileño, y el problema a resolver es responder a esta pregunta, de la cual surgen dos hipótesis: (i) la primera, si la criminalización del "enriquecimiento ilícito del agente público" es compatible con el sistema penal brasileño; (ii) la segunda, si la criminalización del "enriquecimiento ilícito del agente público" no es compatible con uno, varios o todos los principios que orientan el sistema procesal penal brasileño.

Esta investigación también tiene una utilidad práctica específica, que es entregar al poder legislativo, al poder judicial, a los fiscales y a la defensa pública y privada material técnico específico en relación con la criminalización del enriquecimiento ilícito, ya sea para la fase de deliberación legislativa o para la interpretación del texto legal que puede ser editado.

Para solucionar el problema fue necesario analizar las convenciones internacionales antes mencionadas y las propuestas actualmente en estudio en Brasil, para de ellos deducir un texto común, que deberá ser comparado con los principios que guían el proceso penal brasileño.

El primer obstáculo para la institución de cualquier delito en Brasil es la demostración de que la criminalización de esa conducta es necesaria, ya que la sanción penal es la ultima ratio. De ese modo, de inicio es imprescindible verificar, si la conducta a ser criminalizada (i) viola un bien legal protegido, y que (ii) se han frustrado otras formas de combatirlo.

Con base en estas premisas, se creó el capítulo I, cuyo primer objetivo es demostrar la gravedad de los efectos de la corrupción brasileña. Para eso se realizó un análisis de consecuencias de la corrupción en Brasil, a través del cual fue posible concluir que es una situación que causa varias calamidades de la más diversa naturaleza, que pueden estar relacionados con los mayores problemas brasileños, como la falta de seguridad, educación, salud, empleo e infraestructura, solo por nombrar algunos ejemplos.

A su vez estos representan tasas lamentables como muertes prematuras por enfermedades que podrían curarse con saneamiento básico; accidentes de tránsito 
que podrían evitarse con inversiones en las carreteras o en otros medios de transporte menos riesgosos; así como una mejor remuneración y equipamiento para la policía y otros agentes vinculados al enjuiciamiento penal; la construcción de hospitales y la capacitación de médicos, por mencionar algunos ejemplos.

Un trágico ejemplo reciente es la falta de hospitales, equipos médicos y profesionales de la salud necesarios para hacer frente al COVID-19, en un país que en los últimos años ha gastado más de diez mil millones de euros en obras sobrefacturadas, como para la Copa del Mundo de fútbol y los Juegos Olímpicos, muchas abandonadas hoy, por citar sólo dos ejemplos dramáticos de colosales elefantes blancos.

Aún en este ítem, fue posible concluir que la corrupción brasileña se ve especialmente agravada por tres factores, a saber: la colosal estatura de la riqueza brasileña, el porcentaje de corrupción admitido en los contratos públicos en Brasil y la inmensa población afectada por esta práctica, que combinados generan un inmenso problema social.

Como contraste con las conclusiones alcanzadas, si el mismo porcentaje de corrupción si fuera aplicado a una menor riqueza, el resultado de la cuenta sería menos drástico y, finalmente, si este escenario ocurriera en un país menos pobre, menos desigual y que la población dependería menos de la acción del Estado, el problema también se reduciría. Sin embargo, los tres factores juntos causan una verdadera tragedia humanitaria que solo se puede comparar con las guerras.

El segundo objetivo de este capítulo fue descubrir los orígenes históricos de la corrupción en Brasil, a fin de buscar (i) los orígenes de tal fenómeno, especialmente (ii) si es algo reciente o antiguo, (iii) hasta qué punto la corrupción está impregnada en la cultura nacional y (iv) si es posible identificar en una línea si la tendencia está empeorando o no.

Con este fin, se realizó un análisis histórico de la corrupción brasileña, desde su descubrimiento hasta el presente.

Para él fue posible señalar que las fechorías, los intercambios de favores, la falta de celo por lo público y la prevalencia del interés individual sobre el colectivo es 
un fenómeno que se ha identificado desde las primeras expediciones a Brasil, y que puede haberse originado en el naturaleza extractiva de los primeros exploradores, así como en el uso de la tierra colonizada como refugio efímero de la corte portuguesa.

Obviamente, el objetivo de la investigación no es llevar a cabo un análisis sociológico y antropológico de los orígenes de la corrupción en Brasil, sino solo verificar que esta no sea una manifestación reciente y puntual, sino algo que desafortunadamente ya se ha incorporado a la cultura.

El término corrupción ha cambiado mucho durante los cinco siglos que fueron objeto de análisis. A pesar de mantener la raíz de la ruptura, pasó de ser algo más genérico a algo más específico, que puede materializarse en un acto.

Se analizaron las raíces morfológicas del término y la forma en que actualmente es aceptado y disciplinado. Se descubrió que la corrupción brasileña es algo antiguo, duradero, incorporado a la cultura, que causa un gran daño al país y que actualmente está bien definido por el sistema legal, lo que justifica su elección como una conducta para combatir.

Otra dificultad en la lucha contra la corrupción radica en que es un crimen sin víctimas aparentes. En un hipotético robo a un banco, la aseguradora y la institución bancaria están interesadas en resolver el crimen e identificar y arrestar criminales, eventualmente incluso utilizando su poder económico y político para presionar a las autoridades públicas que, en el análisis final, pueden influir en la energía que se destina al enjuiciamiento penal. De otro modo, los delitos de corrupción tienen como víctima el erario que, especialmente en Brasil, sirve a los más pobres que necesitan los servicios públicos; los ricos, como ya se mencionó, no los necesitan porque pagan los privados.

Las víctimas, por lo tanto, son los pobres, una población silenciosa recordada por la gran mayoría de la clase política solo en las elecciones, y que, debido a la ignorancia a la que son convenientemente condenados, no tienen sentido crítico para asociar su desgracia con aquellos que cada dos años les ofrecen un trabajo para agitar banderas en las semanas previas a las elecciones, sánduches o cualquier otra baratija. 
Este mecanismo macabro es perfecto y ha funcionado con precisión de reloj durante más de un siglo y, a su vez, como se puede ver en el recorrido histórico realizado al comienzo de la investigación, es una reinterpretación de lo que sucedió en el episodio del desembarco portugués para el evento de la primera misa. Como dicen en Brasil, "los payasos cambian pero el circo es el mismo".

Como se mencionó, la criminalización de una conducta depende de la demostración de que viola un bien jurídicamente relevante y, al mismo tiempo, han fallado otros medios menos graves para combatir la corrupción. Evidenciada la gravedad de la conducta, queda por probar el fracaso de los otros medios ya empleados para combatirla.

El Capítulo I también está dedicado a los mecanismos utilizados en Brasil para combatir la corrupción, especialmente aquellos relacionados con (i) cambio la cultura, (ii) mejora del sistema legal y (iii) creación de instituciones dedicadas total o parcialmente a la lucha contra la corrupción. Al respecto, merecen mención importantes institutos como la Lei de Improbidade Administrativa, Lei de Lavagem de Dinheiro y la internalización de la Convención Interamericana contra la corrupción de la Organización de los Estados Americanos, la internalización de la Convención de las Naciones Unidas contra la Corrupción y la Lei das Organizações Criminosas.

Criminosas, solo por mencionar algunos ejemplos que fueron analizados. Se mencionó el desmantelamiento del proyecto de Dez Medidas Contra a Corrupção por el Congreso Nacional y, finalmente, las medidas que se están siendo estudiadas: las Novas Medidas Contra a Corrupção y el Projeto de Reforma do Código Penal.

A partir de este análisis, fue posible concluir que la corrupción, en sus diversos significados, es un mal que ha afectado a Brasil desde su período colonial, integrando la cultura nacional, en la que adoptó formas aparentemente inofensivas como malandragem, "jeitinho brasileiro" y la cultura de siempre sacar provecho de algo. Estas son manifestaciones específicas de un comportamiento que puede resumirse como poner el interés individual sobre el interés público y que evoluciona hacia una gran corrupción, con sus grandes males.

También se concluyó que la corrupción funciona como un Robin Hood al revés, retirando dinero de los pobres para entregarlo a los ricos, en un país donde 
los menos favorecidos son extremadamente necesitados de todo, lo que hace posible culpar a la corrupción por el abismo social brasileño y por varias muertes, que podrían ser evitadas con inversiones públicas.

Adicionalmente, la corrupción ha sido resistente a las innovaciones culturales, legales e institucionales, hasta el punto de alcanzar la corrupción sistémica ocurrida en las primeras dos décadas del siglo XXI, cuando la corrupción verdaderamente dominó muchas instituciones federales, estatales y municipales.

Con este análisis también fue posible concluir que el desarrollo de tecnologías científicas, especialmente las relacionadas con las comunicaciones y el almacenamiento de información en la red, podría haber ayudado en la lucha contra los crímenes de sangre; con la posibilidad, por ejemplo, de la creación de bases de datos electrónicas y cruce de información de delincuentes, que hasta hace poco tiempo se hacían en cuadernos, carpetas y fotografías colgadas en las paredes.

Sin embargo, esta misma tecnología permitió la aparición de nuevos delitos, como los electrónicos, y también influyó profundamente en los delitos relacionados con la

corrupción, cuyos criminales también dejaron de usar cuadernos, cartas y maletas de dinero para emplear sistemas de comunicación cifrada punto a punto, accesible a través de diversos app que funcionan en cualquier teléfono celular barato, hojas de cálculo almacenadas en la red con una contraseña de dos factores y criptomonedas. Esto dificulta la aplicación y el cumplimiento de la ley, y a su vez permitió que los delincuentes pasaran a practicar la corrupción y el lavado de dinero de forma mucho más fácil y segura.

En vista del fracaso de los diversos mecanismos creados para combatir la corrupción y la gravedad del problema, en Brasil y en todo el mundo, las mencionadas Convenciones internacionales contra la Corrupción propusieron que los países signatarios empleasen otra forma de combatir la corrupción, dentre as cuales criminalizando el enriquecimiento ilícito del agente público dentro de las posibilidades legales del ordenamiento jurídico de cada signatario, entre los cuales se encuentra actualmente Brasil. 
Por lo tanto, surgió el problema en torno al cual gravita la presente investigación, a saber, si este nuevo crimen sería compatible con el sistema procesal penal brasileño.

El capítulo II se dedica al análisis de lo que en efecto es el enriquecimiento ilícito, un término plurívoco, por lo tanto, con diferentes significados, que pueden referirse a varias conductas distintas, desde la ganancia de cualquier beneficio ilícito como el uso de un bien público, un intercambio de favores disfrazado de regalo, hasta la diferencia incongruente en el patrimonio, que es el punto central de esta investigación.

La primera dificultad para estudiar el enriquecimiento ilícito del agente público en Brasil se debe al hecho de que la declaración legal que establece este hecho delictivo aún no existe en el sistema legal brasileño, lo que explica la necesidad de analizar los tratados internacionales antes mencionados que prevén esta conducta, así como los proyectos bajo análisis en Brasil.

Entonces surge la necesidad de definir cuál es el concepto de enriquecimiento ilícito que será objeto de la investigación, y en este caso específico es el patrimonio incongruente o patrimonio que el agente público no puede explicar razonablemente en función de sus activos legales y declarados. En otras palabras, el agente público brasileño ya no podrá tener un activo que no sea justificable con base en sus ganancias legales.

Para llevar a cabo este estudio fue necesario analizar la pertinencia de criminalizar una conducta que, vista desde una perspectiva simplista, puede parecer inofensiva, que es el enriquecimiento injustificado porque, después de todo, como dicen los que se oponen a la criminalización de la conducta, (i) no habría problema con la posesión de activos que no pueden explicarse, (ii) que no se puede exigir al acusado que explique los activos y (iii) que es deber de las autoridades públicas evitar la práctica de delitos cuando ocurren, criminalizando y fiscalizando los actos ilegales y no la consecuencia de ellos, porque siempre quedaría la aplicación del principio "in dubio pro reo".

Otro argumento contrario a la criminalización del enriquecimiento ilícito es que penalizar un conducta posterior al delito que se desea combatir demostraría la 
incompetencia o incapacidad del Estado para cumplir con las normas legales, tomando la forma más fácil de buscar un hecho posterior, en lugar de atacar el crimen.

Todos estos argumentos merecen respeto, sin embargo, la larga línea evolutiva trazada sobre la corrupción en Brasil -que culminó con el state capture o corrupción sistémica el siglo XXI- sirvió para demostrar que los crímenes vinculados a la corrupción practicados por agentes públicos son responsables de la desgracia de un país continental; causando indirectamente la muerte de decenas de miles de personas en todo Brasil, y que si las prácticas criminales evolucionan y empeoran, las formas de combatirlo también deben evolucionar y empeorar.

El derecho procesal penal, originalmente diseñado para responder a los males que afligieron a la sociedad en un momento dado, debe adaptarse para combatir los crímenes de hoy, bajo el riesgo de que el derecho procesal penal continúe siendo efectivo para arrestar a niños pobres de la periferia, pero absolutamente inútil en relación con los corruptos ricos y poderosos que saquean la nación. En este sentido, Brasil tiene que elegir si sigue siendo un paraíso para los delincuentes de cuello blanco o si evoluciona para permitir la lucha contra estos males que, mediante el saqueo del tesoro, paradójicamente transformaron el país en un matadero para los pobres.

Quizás el mayor problema es que esta decisión de cambiar es tomada por personas que forman parte de una clase social que no siente los efectos causados por la falta de dinero público, ya que no dependen del transporte público, las escuelas públicas, no viven en periferias sin alcantarillado, y no dependen de hospitales públicos en cuyos corredores los pacientes mueren esperando pacientemente para recibir tratamiento médico.

Dada la imposibilidad de identificar toda la corrupción en el momento en que ocurre-como sería ideal pero utópico-, tipificar la posesión del producto del delito, en este caso el enriquecimiento ilícito del agente público, es una estrategia que ya se utiliza ampliamente en otros delitos, como la receptación. Partiendo de la premisa de que el corrupto practica el crimen con el objetivo de disfrutar el dinero, evitar este disfrute hace que el delito sea menos atractivo. 
El segundo objetivo del capítulo II fue analizar cómo la criminalización del enriquecimiento ilícito ya había sido positivizada en el sistema legal brasileño, para demostrar que esta no es una nueva aventura legislativa. Sin embargo, debe tenerse en cuenta que la Constitución Federal de 1988 estableció un nuevo paradigma con respecto a los derechos y garantías fundamentales, razón suficiente para que el tipo penal ahora sea analizado bajo el prisma de la Constitución actual.

El tercer punto del capítulo II se refiere a la definición del concepto de enriquecimiento ilícito del agente público, que implica conocer los dos conceptos, a saber, "enriquecimiento ilícito" y "agente público". En relación con los sujetos activos del crimen, los tratados internacionales antes mencionados tratan del enriquecimiento ilícito de "servidores públicos" y a este respecto, el hecho de que en el derecho brasileño este término representa solo una especie de género de las personas que actúan para el Estado y que se llaman Agentes Públicos, y surge la necesidad de sugerir que la ley que se editará en Brasil contempla el término general, no el específico. De esta manera, el delito en sí mismo puede ser cometido por cualquier persona que tenga una relación con el Estado, independientemente de la duración, la remuneración y la formalidad de esta relación.

Para determinar el hecho delictivo y aislar el bien jurídico protegido por el delito de enriquecimiento ilícito, fue necesario entrar en los elementos centrales del hecho que aún no se ha criminalizado en Brasil. Esta actividad se llevó a cabo teniendo en cuenta los términos empleados en los tratados internacionales antes mencionados y en las propuestas existentes: las Novas Medidas Contra a Corrupção y la Reforma do Código Penal.

Se trata de un delito especial, un crime próprio que solo puede ser practicado por una categoría de personas -en este caso los citados agentes públicos- un género que incluye a todos aquellos que, en general, actúan para la Administración Pública y que fue diseñado para que no hubiera dudas sobre su amplitud semántica. Mientras las convenciones internacionales antes mencionadas utilizan el término funcionários públicos, se concluyó que existe la necesidad de una adaptación para que en Brasil el término sea reemplazado por agente público, como ocurrió en la Lei de Improbidade Administrativa. 
Al analizar los términos enriquecimiento ilícito y patrimonio no justificado fue posible concluir que pueden significar una amplia gama de comportamientos, desde el uso aparentemente inocente de un bien público, hasta regalos, para llegar incluso a las ventajas indebidas que señala el Código Penal cuando se trata del delito de corrupción. Sin embargo, el enriquecimiento ilícito del que se ocupa la presente investigación no corresponde a ninguna de estas conductas, sino a la del agente público que muestra lo que se puede llamar "patrimônio incongruente", es decir, una propiedad cuyo origen no pueda ser explicado.

En este momento, debe tenerse en cuenta que el término patrimonio ostensivo es extremadamente complejo y su comprobación generalmente dependerá de la prueba por indicios, también llamada prueba indirecta, que está sujeta a críticas constantes, como se analizará en el capítulo III.

Al tratar con las formas de enriquecimiento ilícito, fue posible establecer una escala de sofisticación para este crimen, en la cual la forma menos sofisticada de hacerlo es que el agente público reciba un cheque de la persona que fue favorecida por el acto corrupto y lo deposite en su cuenta bancaria, lo que generaría pruebas directas. No obstante esta prueba directa no se espera en crímenes mayores, ya que el departamento legal y el departamento contable de la organización criminal no permitirían tal ingenuidad.

La segunda forma menos sofisticada de enriquecimiento ilícito es el registro de la propiedad de un bien comprado con dinero ilícito, como un automóvil, lancha motora, avión o propiedad ubicada en el municipio y en el estado donde vive, hechos fácilmente rastreables por las autoridades públicas dedicadas a combatir la corrupción. Esta conducta gana sofisticación cuando la propiedad está registrada en un lugar distante; sin embargo, con la unificación de la información de los registros de bienes raíces esto se volvió prácticamente irrelevante. La sofisticación aumenta cuando los corruptos usan cuentas bancarias en el extranjero, especialmente en paraísos fiscales, pero hoy también es un recurso difícil debido al intercambio de datos. 
Al subir aún más la escala de la sofisticación, existe la posibilidad de que el criminal pueda recibir su soborno a través de obras de artes o joyas, fáciles de transportar y sin la posibilidad de rastrear, mas que pueden ser objeto de decomiso.

El mayor grado de sofisticación que existe actualmente es el uso de criptomonedas, o algunas transferencias electrónicas por app que no están controladas por ningún sistema oficial y pueden retirarse con tarjetas de crédito en cualquier parte del mundo, por lo que hasta entonces no se pueden rastrear. Con ellos, el criminal puede comprar virtualmente cualquier cosa en cualquier parte del mundo sin que el bien esté vinculado a él, como también sucedería si usara la tarjeta de crédito de otra persona, generalmente el deudor del soborno o alguien que lo represente. De esta manera, el agente público corrupto puede comprar o que lo quiera, pagar hoteles cuyas tarifas diarias equivalen a un año de su salario, o casas en playas paradisíacas.

Otra conducta muy interesante que se caracterizó como enriquecimiento ilícito es la enajenación de una propiedad incompatible con el patrimonio, que busca evitar que el corrupto venda el producto de su crimen. Admitir esta hipótesis sería crear una puerta de escape para el crimen del cuello blanco, y a la menor señal de que se descubrió el patrimonio ilícito, transmitirlo a un tercero para evitar la caracterización del crimen. La necesidad de criminalizar el enriquecimiento ilícito como una forma de combatir la corrupción y otros delitos de cuello blanco surge del hecho de que, con la evolución de las tecnologías de comunicación, se ha vuelto prácticamente imposible identificar la mayoría de estos delitos cuando ocurren, haciendo necesario usar la máxima follow the money y seguir el rastro del producto del delito para evitar que el criminal disfrute de las ventajas de su delito, empeorando su costo beneficio.

Como se mencionó, actualmente hay organizaciones criminales bien asesoradas, especializadas en practicar la corrupción sin dejar pruebas directas de los delitos o destruirlas rápidamente. Una de las recomendaciones más comunes es que los corruptos no transfieran a sí mismos la propiedad de los bienes que reciben como beneficio del delito, ya que esto permitiría el seguimiento mencionado a través del cruce de datos. La nueva estrategia es recibir de manera informal el bien utilizado como pago, usarlo con animus domini, como se fuera suyo, pero dejando para transferirlo formalmente solo después de unos años, para no despertar 
sospechas. Se trata de un verdadero recuento de lo que hicieron los piratas al enterrar un tesoro para solo después de ello usufruirlo. Son los saqueadores del pasado todavía influyendo en los del presente.

Entre las propuestas contenidas en las Novas Medidas contra a Corrupção se encuentra el procedimiento llamado pedido de justificação de patrimônio incompatível, instituto que recibirá muchas críticas de aquellos que llevan a cabo una interpretación demasiado extensiva del derecho al silencio y de la garantía a la no incriminación, de lo que trata el capítulo V.

Este procedimiento consiste en la judicialización de la investigación sobre el origen del patrimonio incongruente de un agente público, y se practica dentro del alcance del poder judicial, donde el principio de contradicción y el principio del debido proceso legal estarán más asegurados. Las críticas a estos institutos se basan en una premisa errónea de que la falta de explicación del origen del patrimonio sería parte del tipo, pero de hecho es una exclusión de la tipicidad, de lo que también trata del capítulo $\mathrm{V}$.

Otra pregunta relevante sobre los aspectos criminales del delito de enriquecimiento ilícito que se pretende instituir en Brasil tiene que ver con su efectividad a lo largo del tiempo, ya que el derecho penal brasileño prohíbe que una nueva norma penal tenga efectos en relación con los hechos que ocurrieron antes de su entrada en vigencia, lo que obviamente permite excepciones, cuando, por ejemplo, es más beneficioso para el acusado, un tema que en sí mismo no contiene grandes controversias pero fue tratado en el capítulo II.

Siguiendo esta regla general, la nueva ley no podría penar al agente público que tenga activos resultantes del enriquecimiento ilícito practicados antes de su entrada en vigor, lo que permitiría a todas las personas que hubieran ganado dinero ilícito en el pasado disfrutar libremente del valor que les han robado a los contribuyentes, esto sería, como mínimo, un chiste para las personas honestas.

Siendo el enriquecimiento ilícito un delito de mera conducta que se renueva a cada instante, este se extiende a lo largo del tiempo mientras dure la situación de hecho; como sucede, por ejemplo, con quien mantiene la moneda falsificada o bienes robados. 
Desde el punto de vista teleológico del Código Penal, que busca salvaguardar el derecho de quienes practicaron un acto antes de que se volviera ilegal, fue posible concluir que el criminal puede deshacer los activos adquiridos ilegalmente, especialmente con la devolución del efectivo al erario, hasta la fecha de inicio de vigencia de la ley.

También hay una crítica según la cual el delito de enriquecimiento ilícito del agente público no sería compatible con el sistema procesal penal brasileño debido a que faltaria un bien jurídico protegido. En relación a esto, fue posible concluir que lo que se busca resguardar con la criminalización del enriquecimiento ilícito es la moralidad de la administración pública, expresamente protegida por la Constitución Federal. Este delito también busca salvaguardar la publicidad o transparencia que la Constitución atribuye a la administración pública, de modo que sea posible asegurarse de que el patrimonio ostensivo de los agentes públicos tenga un origen legal.

La criminalización del enriquecimiento ilícito también protege la isonomía en la que debe basarse cualquier régimen republicano y democrático, ya que al criminalizar el enriquecimiento ilícito, se inhibe la corrupción y se establece una igualdad entre agentes públicos honestos y deshonestos, que deben ser tratados con desigualdad, pero actualmente no lo son.

La sociedad brasileña tiene el derecho de asegurarse de que los funcionarios públicos, a quienes se atribuyen grandes poderes, no los usen para su propio beneficio, y que los activos que exhiben provengan exclusivamente de fuentes legales, porque de lo contrario sería posible concluir que estarían utilizando su función pública a favor de intereses propios.

Todo este conocimiento fue necesario para establecer algunas conclusiones previas, como (i) la necesidad de criminalizar el enriquecimiento ilícito, (ii) los elementos nucleares del tipo y (iii) su posibilidad de alcanzar los bienes obtenidos en el pasado.

El Capítulo III se dedicó a una de las críticas más severas recibidas por la criminalización del enriquecimiento ilícito en Brasil, a saber, que algunos de los elementos del tipo criminal enriquecimiento ilícito del agente público sólo podrían 
probarse mediante pruebas indirectas también llamadas pruebas por indicios, y que este tipo de evidencia no sería capaz de establecer la certeza más allá de toda duda razonable, esencial para una condena penal.

Estas críticas motivaron el estudio de la prueba, que a su vez condujo a una investigación de su función para la construcción del hecho jurídico y, finalmente, su función en la norma legal.

El propósito del Capítulo III es establecer los fundamentos esenciales para demostrar que la prueba indirecta no es más débil o más insegura que la prueba directa, ni representa riesgo para la seguridad de las decisiones judiciales, ya que no conduce a un grado de menor certeza de la verdad sobre algo.

El primer ítem del capítulo III está dedicado al estudio de la estructura lógica de la norma jurídica. Esto se debe a que para comprender el concepto de prueba indiciaria y su papel en la aplicación de la ley, es necesario conocer la estructura lógica de las normas para, a partir de ahí, identificar la función de los hechos como elementos a los que se subsumen las hipótesis; hechos sobre los cuales debe haber una certeza sobre la verdad de su ocurrencia, una certeza que puede provenir de lo que se llama prueba directa o prueba indirecta, aunque también hay hechos que son independientes de la prueba.

Para hacerlo, también es necesario entrar en el concepto de normas, verdad, certeza, para que se puedan conocer los estándares probatorios, especialmente el de certeza más allá de una duda razonable.

Esto ocurre porque todas las normas legales tienen una estructura lógica similar, que puede resumirse como la conjunción de una norma primaria y una norma secundaria; la primaria con una consecuencia legal a un hecho, y la secundaria con una sanción por incumplimiento de la primaria. Toda esta operación lógica parte de la observación de un hecho que se subsuma a la hipótesis contenida en el antecedente de la norma, ya sea primaria o secundaria. El hecho, a su vez, no es algo físico, no es un evento, ni corresponde necesariamente a un acontecimiento; y se puede decir que es el lenguaje producido sobre algo que realmente pudo haber sucedido, o no, teniendo en cuenta las reglas que autorizan la producción lingüística en el ordenamiento jurídico. 
En este punto, es importante enfatizar que en la operación lógica de aplicar un estándar, se debe tener en cuenta que hay dos planes. A saber: el plan fenoménico, en el que ocurren los eventos, y el plan normativo, que no es más que una ficción hecha por el hombre, compuesto solo de normas legales que se crean, modifican y extinguen todos los días -con mayor o menor intensidad-, también conocido como el sistema legal.

En el proceso no ingresan bienes físicos como el cuchillo del crimen o la maleta de dinero, sino solo el lenguaje que se produce sobre ellos, lo que comúnmente se conoce como hecho. Los hechos son generalmente alegados por las pAres en las hipótesis argumentativas construidas por ellos, y que generalmente deben ser probadas, surgiendo así la necesidad de establecer quién probará el hecho, también conocido como la carga de la prueba.

La prueba, a su vez, no es más que otro lenguaje, producido por personas y en la forma autorizada por el sistema legal, generalmente mediante el uso de la "verdad por correspondencia" que debe compararse con el lenguaje de la hipótesis argumentativa, y la identidad entre ellos constituye la "verdad por coherencia".

Para la ley, algo es cierto cuando se puede decir que está probado, lo que a su vez significa que existe una identidad relativa entre el lenguaje de la hipótesis argumentativa y el lenguaje de la prueba. Hay hechos que pueden alegarse verdaderos independientemente de la prueba, como los notorios, presuntivos y ficticios, y aquellos que no necesitan ser probados o siquiera alegados, pero sobre los cuales el juez puede producir un lenguaje independiente de provocación, como el conocimiento del oficio.

La cuestión de la prueba se centra en los hechos que el sistema establezca que necesitan ser probados, y la carga de la prueba también recae en quien sea que el sistema imponga. Para comprender mejor este fenómeno, es necesario entrar en teorías sobre la verdad, especialmente la "verdad como correspondencia", la "verdad como coherencia" y la "verdad como consenso".

Sintéticamente, la "verdad como correspondencia" se obtiene al comparar un enunciado con el objeto, a través del cual el intérprete puede afirmar que algo es verdadero. Mientras el intérprete pueda llegar a la verdad por medio de la 
correspondencia, nunca podrá afirmar haberla alcanzado, ya que siempre podrán surgir nuevos datos o tecnologías que destruyan la verdad por correspondencia. Es a través de la "verdad como correspondencia" que un experto dice que la sangre en la ropa del acusado pertenece a la víctima, o que la firma en el documento fue dada por cierta persona, a pesar de que se sabe que esta verdad siempre se puede superar.

La "verdad como coherencia" es la verdad lógica que predomina dentro de un sistema y, en derecho, se manifiesta cuando se comparan dos lenguajes, como ocurre con las pruebas. Cuando el lenguaje de una prueba coincide con el lenguaje de una hipótesis argumentativa, se da la "verdad como coherencia", aunque no se sabe si el lenguaje de la prueba, producida por la "verdad como correspondencia", es verdadero.

Es importante resaltar que la "verdad como correspondencia", generalmente utilizada por aquellos que producen lo que se llama prueba, no puede considerarse absoluta, porque incluso si una conclusión es finalmente cierta, esto nunca puede afirmarse. Lo que lleva a otra conclusión, que es que la prueba no genera verdades absolutas sino probabilidades y certezas, siempre relativas.

Para facilitar la aplicación de la ley y permitir una relativa igualdad en el tratamiento de los hechos y del acusado, las certidumbres fueron graduadas en estándares, que van desde una certeza muy baja a una certeza muy alta, de las cuales se puede llegar a la conclusión de que algo es cierto a menos que haya ocurrido un hecho extremadamente improbable e irracional, lo que se denomina certeza más allá de toda duda razonable.

Se reitera que no hay certeza absoluta ni verdad absoluta por correspondencia, razón suficiente para que no puedan ser exigidas como condición esencial para ningún juicio, ya que esto implicaría la absolución de todos los acusados; lo que a su vez conduciría a la condena de todas las víctimas a la injusticia, la condena de la inutilidad de todo el sistema legislativo, ejecutivo y judicial, así como la condena de la civilización a la barbarie.

En este punto, es importante reiterar que no se predica el error, y mucho menos la condena de los inocentes como una especie de efecto secundario 
admisible para penalizar a los culpables, en una visión utilitaria según la cual algunos son sacrificados a favor de la mayoría, pero admitiendo la posibilidad de su existencia como algo inherente al sistema.

Con el análisis de las principales y más recientes sentencias emitidas por el Supremo Tribunal Federal fue posible concluir que el estándar de certeza más allá de una duda razonable -utilizado expresamente por la ley estadounidense, así como aceptada por la jurisprudencia de muchos otros países-, también es admitido por ordenamiento jurídico brasileño como estándar necesario para una condena penal.

Fue posible concluir también que los estándares son variables de acuerdo con el acto procesal que se practicará, por ejemplo, una certeza más baja en algunos actos y una certeza mayor en otros; la cantidad de evidencia necesaria para cumplir un determinado estándar puede variar de acuerdo con el universo de evidencia disponible en el caso específico, por ejemplo: el hecho de que los delitos con menos potencial para producir prueba pueden ser probados con menos evidencia que los delitos con mayor potencial para hacerlo. En este sentido, también debe tenerse en cuenta el desempeño de la fiscalía, específicamente si agotó las posibilidades de investigación, que deben tenerse en cuenta para llegar a la seguridad del juez.

Esta estructura lógica empieza desde el momento en que alguien autorizado por el sistema -por ejemplo, un fiscal- establece una hipótesis argumentativa según la cual, en el plan fenoménico, ocurrió un evento hipotéticamente subsumido a una hipótesis normativa, por ejemplo, que un agente público recibió un soborno para realizar un acto. Esta hipótesis argumentativa no irá más allá de esto hasta que se pruebe el hecho, y la prueba no es más que un lenguaje construido por quienes el sistema establece la competencia para hacerlo, por ejemplo, el testimonio de quienes pagaron el soborno, que a su vez se demuestra en otro lenguaje, o el lenguaje de una grabación del momento del pago, por ejemplo.

Un hecho es cierto cuando la persona calificada por el sistema para verificar el lenguaje de las hipótesis argumentativas afirma que existe coherencia entre esta y el lenguaje de la prueba.

Este hecho, ahora comprobado, debe ser comparado con una hipótesis legal, una actividad llamada subsunción, que es realizada por la persona autorizada por la 
ley, generalmente el juez. Si no hay esta subsunción, el hecho es considerado atípico, pero si hay subsunción, el hecho es típico, es decir, se subsume al tipo penal y por esto genera efectos en el derecho. En este caso, se aplica la consecuencia prevista en el sistema legal, que dentro del derecho penal generalmente se conoce como sanción.

Se concluye, así, que la estructura lógica de la norma jurídica depende, para su aplicación, de un hecho. Para que se tenga certeza de la verdad de este hecho, constituido por lenguaje, generalmente necesita ser probado, lo que se da por otro lenguaje, llamado prueba. Si el intérprete tiene certeza acerca de la verdad de este hecho, el próximo paso es compararlo con una hipótesis normativa y, si hay subsunción, crear una norma individual y concreta que consiste en la aplicación de la sanción. Por ejemplo la prisión del acusado.

En todo caso la prueba es siempre relacional, un lenguaje que genere certeza acerca de la verdad del lenguaje de la hipótesis argumentativa de una parte, siendo la distinción entre la prueba directa e indirecta irrelevante para fines de afirmar sobre la fuerza de una o de otra.

El capítulo IV hace uso de las consideraciones ya establecidas acerca de las normas, la verdad, la certeza, la prueba y los estándares probatorios para concluir sobre la capacidad de la prueba para probar algo, es decir, para establecer la certeza de cualquier cosa. Para eso es necesario entrar en la definición del concepto de prueba y fijar la diferencia entre las pruebas directas y las indirectas.

Para cumplir este objetivo, es necesario conocer la llamada teoría clásica de la prueba indirecta, analizar las objeciones establecidas a ella, y luego concluir que la diferencia entre una prueba directa y una prueba indirecta es tan solamente circunstancial; no siendo posible decir que la certeza lograda por una prueba por indicios es menos segura o más débil que la obtenida por una prueba directa.

En el caso específico de la presente investigación, los hechos enriquecimiento ilícito, patrimonio no razonablemente justificado y posesión no eventual de bienes de terceros merecen una mención especial, por indicar algunos hechos de lo que se debe probar. 
Por una razón didáctica, la ciencia del derecho clasifica las pruebas en varias categorías, y para esta investigación merece destaque las clasificación en pruebas directas y pruebas indirectas, fuentes de innumerables discusiones que originaron varias corrientes doctrinales a través de las cuales se busca definir la distinción entre ellos, además de explicar una posible diferencia en peso, grado, jerarquía o fuerza.

El estudio de la prueba indiciaria es fundamental para la investigación, especialmente porque con la antes mencionada especialización del crimen organizado, no se espera que los delincuentes de cuello blanco produzcan pruebas directas de sus crímenes -como recibos de soborno- o que se registren a sus nombres bienes incompatibles con sus activos. También se imagina que todos los documentos, cuando son producidos, sean rápidamente destruidos por la organización criminal.

Para los propósitos de la presente investigación, la distinción entre prueba directa y prueba indirecta reside en el hecho de que la proposición prueba directa establece una certeza sobre un hecho que se subsume directamente a una hipótesis contenida en una norma penal o el hecho a probar; que se llama delito, hecho delictivo o factum probandum. Este hecho, independientemente de la denominación, se subsume a la hipótesis normativa, que a su vez se denomina tipo penal.

La prueba por indicios, por otro lado, establece certeza sobre un hecho que no es exactamente el hecho de que subsume una hipótesis criminal, también llamada factum probans; sin embargo, es capaz de generar, aunque sea indirectamente, la certeza de que ocurrió el hecho típico.

La pregunta que surge, entonces, es si la prueba indirecta tendría o no la capacidad de establecer, en el juez, certeza además de una duda razonable sobre el hecho que se pretende probar, el estándar necesario para una condena penal. Esta conclusión solo se puede alcanzar por medio del análisis de las pruebas a través del prisma de las teorías ya estudiadas sobre la norma, la certeza y la verdad, previamente realizadas en el capítulo III.

Mediante la unión de este conocimiento es posible verificar que la prueba es un hecho, que este hecho es una construcción lingüística que depende de la percepción de quien argumenta. 
En vista de la incapacidad humana para aprehender y comprender un evento al máximo, debido a la falibilidad de la verdad por correspondencia, mucho menos almacenar esta información y reproducirla con precisión es posible decir que nadie puede afirmar con absoluta certeza que vio un cierto hecho; solo que vio algo que él cree que es un hecho cierto, como un homicidio o el pago de un soborno, por ejemplo. Esta certeza proviene del hecho de que el observador vio indicios que lo llevaron a pensar lo que él cree que es, por ejemplo, dos personas dándose la mano y una entregando una maleta a otra; este lenguaje es lo que se llama prueba directa, deificada por muchos. La prueba directa no es más que una manifestación lingüística de aquellos que percibieron eventos que les indicaron algo.

En la prueba indirecta, sin embargo, los hechos típicos no se presentan listos para el intérprete, a quien se le llevan indicios de los hechos criminales, cabiendo a este intérprete llegar a sus conclusiones.

No se prueba el soborno, sino solo que el empresario entregó una maleta de dinero para el político que había creado un beneficio para el mismo empresario algunos días atrás. Hay quien piense que este mecanismo mental generaría una debilidad en las pruebas indirectas, pero técnicamente esto no es verdad.

Vale la pena recordar que las conclusiones que surgen a partir del análisis de los indicios son las mismas de quien enunció la prueba directa, solo que en un ambiente mucho más controlado. Cuando un intérprete utiliza una prueba indirecta, la relación lógica por él establecida es obligatoriamente motivada, transparente y a la vista de las partes, quienes pueden cuestionar (i) las formalidades, (ii) el uso de los indicios e incluso (iii) el razonamiento utilizado para vincular una hipótesis argumentativa a una prueba, formando el hecho; así como el razonamiento utilizado para subsumir el hecho a la hipótesis normativa, que puede ser revisado por un tribunal.

De este análisis queda claro que no es posible afirmar, prima facie, que la prueba directa es más fuerte o más segura que la prueba por indicios que, de hecho, puede ser hasta más confiable, dependiendo del caso específico y los hechos que se buscan probar. La diferencia, entonces, es solo circunstancial y no esencial. Como ya se demostró, la noción de prueba es relacional, porque nada es 
necesariamente una prueba, mientras todo puede eventualmente serlo, dependiendo de las circunstancias; incluso la ausencia de una prueba directa puede ser una prueba indirecta de algo como, por ejemplo, que el crimen fue cometido por un especialista.

Partindo de la premisa que la noción de prueba es relacional, es posible afirmar que su fuerza, peso o persuasión también son circunstanciales y no pueden atribuirse de manera abstracta, sino sólo frente a hipótesis argumentativas y normativas.

Se puede concluir que la aceptación de la prueba por indicios es fundamental para la lucha contra el crimen organizado, especialmente en relación con los delitos de cuello blanco en el siglo XXI. Ignorar tales pruebas implicaría automáticamente la absolución de muchos de los peores corruptos en Brasil, lo que confirmaría el discurso de que el sistema judicial brasileño no es efectivo para castigar los delitos practicados por los ricos y poderosos, especialmente los relacionados con la corrupción.

No se debe perder de vista el hecho de que algunos crímenes y intenciones como la voluntad de matar, la voluntad de causar daños, la ignorancia sobre una persona o un Artefacto- solo pueden ser probados a través de las pruebas indirectas, para las cuales las pruebas directas son absolutamente inútiles; lo que en sí mismo ya aleja cualquier argumento de inferioridad o debilidad.

A través de los estudios llevados a cabo en los capítulos III y IV, fue posible demostrar que no hay obstáculo para que se prueben delitos mediante indicios, así como que no hay diferencia ontológica entre la prueba directa e indirecta, siendo que la distinción que existe entre ellas es meramente circunstancial, y que debe analizarse en cada caso específico, teniendo en cuenta las hipótesis argumentativas establecidas por las Argos, la evidencia que se produjo, la evidencia que podría haberse producido, el tipo de delito que se busca investigar, la forma en que se cometió el delito y, finalmente, la hipótesis normativa.

El capítulo $V$ está dedicado a los otros obstáculos planteados contra la criminalización del enriquecimiento ilícito en Brasil, especialmente aquellos que se originan fundamentalmente del principio de la presunción de inocencia, que a su vez 
se deriva de la cláusula del debido proceso legal, con sus orígenes en el Estado democrático de derecho, inspirado en los valores que nortearon al constituyente.

Anteriormente se demostró que la criminalización del enriquecimiento ilícito por parte del agente público es compatible con el sistema procesal penal brasileño con respecto a la existencia de un bien jurídico a proteger; habiendo demostrado que este nuevo delito servirá para preservar la moralidad de la administración pública, lo que a su vez respalda la relación de confianza que el ciudadano debe fomentar para quienes actúan en su nombre.

También se explicó que la criminalización del enriquecimiento ilícito no viola el principio de mínima intervención del derecho penal, o ultima ratio y sigue siendo evidente que se adoptaron varias medidas para resolver un problema que no parece detenerse, porque a pesar de las innovaciones legales e institucionales, la corrupción en Brasil aún es un delito que vale la pena.

Debido a la importancia del principio de la presunción de inocencia para la presente investigación, ya que resulta de los mayores obstáculos para la criminalización del enriquecimiento ilícito, fue necesario profundizar el estudio de las presunciones en la ley brasileña, diferenciándose de las ficciones -que son verdades previas- concebidas independientemente de cualquier reclamo de correspondencia con los eventos o acontecimientos. Para este propósito, el concepto de presunción se definió como un conocimiento anticipado sobre algo, que puede o no ser cierto. Las presunciones pueden ser relativas, cuando admiten prueba de lo contrario, o absolutas, cuando ni siquiera pueden ser refutadas.

Para la presente investigación, la distinción más relevante entre presunciones radica en la clasificación entre presunciones con una base epistemológica (como las cosas son), y presunciones con base axiológica (como deberían ser). Fue posible verificar que la presunción de inocencia tiene una base axiológica, de ahí que no establece que todas las personas son inocentes -ya que en realidad no lo son-, sino que todas las personas deben ser tratadas como si fueran inocentes hasta que sean declaradas culpables.

En ese momento, también fue posible concluir sobre la moderna interpretación del significado y el alcance del principio de la presunción de inocencia, 
aprovechando las recientes sentencias del Supremo Tribunal Federal específicamente sobre el tema. Estas nos permitieron comprender el significado y el alcance atribuido por él, que inevitablemente apreciará su constitucionalidad.

La presunción de inocencia, de base axiológica, no representa el mundo tal como es, sino un fin que debe lograrse y, para este propósito, el sistema legal otorga a los acusados algunas ventajas procesales específicas, que pueden resumirse como atribuir a la acusación la carga de producir todas las pruebas necesarias para convencer al intérprete sobre la culpabilidad del acusado más allá de una duda razonable. Por otro lado, sobre el acusado recae la carga de generar pruebas que establezcan una duda razonable.

A partir de los estudios y reflexiones realizados en el capítulo $V$, fue posible resolver los principales problemas de esta investigación, que se abordarán en los siguientes puntos:

El primer obstáculo que existe en relación con la criminalización del enriquecimiento ilícito es que el nuevo delito violaría el derecho al silencio del acusado, que a su vez infringiría la garantía de no auto-inculparse y el principio nemo tenetur se detergere. Tales argumentos solamente pueden ser resultado de una lectura apresurada o superficial del término "patrimonio injustificable" o "patrimonio que no puede justificarse" dependiendo de cómo el legislador escriba el texto legal. Esto se debe a que la justificación del patrimonio no es una condición del tipo penal, como si el acusado fuera llamado a justificar el origen del patrimonio, y se consideraría criminal solo si no pudiera llevar a cabo la justificación. Por el contrario, el término "patrimonio que no se puede justificar" no es más que la diferencia entre el patrimonio ostensible del agente y el declarado oficialmente; cuya diferencia se presume ilegal, o sea, obtenida por medios ilícitos. Tal presunción es relativa y el acusado puede refutarla por la justificación del patrimonio. De la misma manera ocurre con todos y cada uno de los delitos que tienen una presunción en su estructura lógica; de hecho, prácticamente todos. Como ejemplo, se presume que alguien atrapado con un cadáver en el baúl de su automóvil está practicando el crimen de "ocultação de cadáver", aunque puede demostrar que hay una razón legal para esto. Del mismo modo, una persona atrapada con un arma para uso restringido por las fuerzas armadas -si no está uniformado en un vehículo militar- se considera 
criminal hasta que demuestre que tiene los atributos legales para usar esta arma, cuya carga debe recaer sobre el acusado; algo que nunca se ha considerado una violación del derecho al silencio o sus subprincipios. En este sentido, el acusado también podría afirmar que la carga de probar el origen del patrimonio incongruente violaría su privacidad, lo que tampoco sería un obstáculo, ya que cuando los procesos tratan de cuestiones patrimoniales o relacionadas con la privacidad del acusado, es posible tratarlo en secreto, como ocurre en cualquier otro delito.

El segundo obstáculo planteado en relación con la criminalización del enriquecimiento ilícito fue que esta invertiría la carga de la prueba en los procesos penales. Tal obstáculo también se debe al falso presupuesto de que la justificación del patrimonio sería una condición de tipo penal, lo que no es verdad. El tipo penal es la incongruencia entre los bienes oficialmente declarados por el agente público y su patrimonio ostensivo, aunque informal. En el derecho procesal penal brasileño, es cierto que recae sobre la acusación la carga de la prueba de los hechos necesarios para una certeza más allá de una duda razonable, y el acusado debe probar los hechos que puedan reducir esta certeza y establecer una duda absolutoria.

En el caso de la criminalización del enriquecimiento ilícito, la acusación debe probar que el agente público posee un patrimonio ostensivo incongruente con su patrimonio declarado y recae sobre el reo la carga de probar su licitud. Esta sistemática es perfectamente compatible con la distribución de la carga de la prueba en el proceso penal. En otros términos, la fiscalía debe presentar todas las pruebas necesarias para establecer en el juez una certeza más allá de la duda razonable, y corresponde al acusado deconstruir esta certeza para generar una duda.

El tercer obstáculo es que la criminalización del enriquecimiento ilícito violaría el principio de que en el proceso penal la duda debe ser interpretada a favor del acusado, lo que se llama el beneficio de la duda o "in dubio pro reo". Esta norma debe aplicarse solamente en el momento de juzgar el proceso y no al presentar las pruebas. La invocación de "in dubio pro reo" se deriva del razonamiento de que si la acusación no puede obligar al acusado a declarar el origen legal del patrimonio, y sí pueden existir infinitos orígenes legales para él, el beneficio de la duda deberia aplicarse para su absolución. Este razonamiento, de la misma manera que los otros, parte de la premisa errónea de que la justificación sería parte del tipo, cuando en 
realidad el crimen ocurre con la verificación de la diferencia entre el patrimonio ostensible y declarado, y la justificación es un excluyente de ilicitud. Se concluyó que la duda existe en todas y cada una de las decisiones que tienen en cuenta la "verdad como correspondencia", y lo que la ley prohíbe es que alguien sea condenado cuando exista una duda razonable sobre la autoría y la materialidad del delito. Siempre habrá dudas, y esto debe ser tratado favorablemente para el acusado, al analizar la probabilidad de la certeza de las acusaciones sobre la legalidad de la propiedad; además, de la misma manera que con todos y cada uno de los delitos.

El cuarto obstáculo consiste en la afirmación de que la criminalización del enriquecimiento ilícito sería un delito de peligro abstracto, prohibido por el sistema legal brasileño. En este sentido, debe tenerse en cuenta que el enriquecimiento ilícito es efectivamente un delito de peligro abstracto, ya que a partir de una conducta determinada se presume que se da el daño en el bien jurídico que se quiere proteger, independiente de cualquier demostración adicional de daño concreto. El error en esta alegación radica en el hecho de que los crímenes de peligro abstracto estarían prohibidos por el sistema procesal penal brasileño, lo cual no es cierto, ya que existen varios crímenes de peligro abstracto en vigencia, sin que haya ningún impedimento para ellos.

Finalmente, el último argumento que podría lanzarse en oposición a la criminalización del enriquecimiento ilícito proviene del postulado normativo de la razonabilidad, cuyos subprincipios son la adecuación, la necesidad y la proporcionalidad en sentido estricto.

Se concluyó que la criminalización del enriquecimiento ilícito es adecuada para combatir la corrupción porque dificulta que los marginales disfruten del producto de sus actos ilícitos, tornando el crimen menos ventajoso. Esto porque la corrupción es generalmente practicada con la intención de recaudar dinero y, si no puede salvarse o ser transformado en bienes, el beneficio se reduce y el riesgo de un delito cometido aumenta a través de un análisis exhaustivo de costo-beneficio.

La medida también es necesaria, cuando se tiene en cuenta que la corrupción puede considerarse uno de los más grandes males que aflige a Brasil, responsable indirectamente por decenas de miles de muertes cada año, sin mencionar las 
incalculables pérdidas tratadas en el capítulo I. Finalmente, se concluyó que la criminalización del enriquecimiento ilícito también pasa por el filtro de la proporcionalidad en sentido estricto, una vez que la presunción de ilegalidad del patrimonio incongruente del agente público es una medida proporcional a los graves males causados por la corrupción en Brasil.

Gracias a la presente investigación fue posible concluir que la criminalización del enriquecimiento ilícito, según lo previsto por los diplomas que se están analizando, no viola ninguno de los principios que nortean el proceso penal brasileño. Esto confirma la hipótesis inicialmente propuesta en el sentido de que no habría violación, especialmente porque el hecho legal examinado se trata como un delito de peligro abstracto y continuo, en el que se presume ilícita la diferencia sustancial entre el patrimonio ostensible y el patrimonio declarado oficialmente por el agente público; un hecho que atenta contra diversos bienes legales protegidos, especialmente la moral de la administración pública.

El crimen de enriquecimiento ilícito admite, sin embargo, que el agente público invalide la presunción de que los bienes tengan un origen ilícito, demostrando que el patrimonio fue adquirido por medios legales. En relación con este argumento, cualquier duda debe interpretarse en favor del acusado, y toda condena solo puede llevarse a cabo frente a una certeza más allá de una duda razonable.

La investigación se llevó a cabo de tal manera que el delito de enriquecimiento ilícito -que aún no ha sido creado en la legislación brasileña- fue estudiado a partir de sus estructuras fundamentales, haciendo posible demostrar que estos elementos no difieren de los encontrados en otros delitos consagrados por la doctrina y jurisprudencia.

Finalmente fue posible concluir que la criminalización del enriquecimiento ilícito es compatible con los todos los principios que rigen el sistema procesal penal brasileño, especialmente: (i) está de acuerdo con el principio de mínima intervención, o de la última ratio (ii) hay un bien legal protegido (iii) es compatible con el debido proceso legal porque la diferencia entre la prueba indiciaria y directa es solo circunstancial, no habiendo una diferencia previa de fuerza o peso en relación 
com la prueba directa; (iv) no viola el derecho al silencio, porque el tipo no pudo tener en cuenta una declaración del acusado sobre el origen de sus activos, lo que podría violar el derecho a la privacidad; (v) es compatible con la regla de distribución de la carga de la prueba en el derecho procesal penal, según el cual corresponde a la fiscalía llevar a cabo todas las pruebas con el fin de establecer la certeza más allá de toda duda razonable; (vi) no representa una violación al principio dubio pro reo; (vii) es un delito de peligro abstracto, pero este tipo de delito está permitido por la ley brasileña, y, finalmente, (viii) está de acuerdo con el postulado normativo de razonabilidad por ser adecuado, necesario y proporcional con el bien jurídico por el protegido. 


\section{REFERÊNCIAS}

\section{REFERÊNCIAS BIBLIOGRÁFICAS}

ABAD, Raphael Madeira. A corrupção como maior ameaça aos direitos fundamentais. o caso brasileiro. Painel apresentado no Seminário Sociedad del riesgo, nuevas amenazas y derechos fundamentales no XXXVIII Curso de especialización en derecho de la Fundación General de la Universidad de Salamanca. Salamanca: 16 de janeiro de 2016.

A eficácia dos princípios da razoabilidade e da proporcionalidade na perspectiva dos direitos fundamentais. Dissertação de Mestrado em Direito e Garantias Fundamentais. Vitória: Faculdade de Direito de Vitória, 2007. Disponível em < http://191.252.194.60:8080/handle/fdv/44?mode=full > acesso em 08 out 2020.

ABBAGNANO, Nicola. Dicionário de filosofia. $5^{\mathrm{a}}$ Ed. São Paulo: Martins Fontes, 2007.

ABEL LLUCH, Xavier. Sobre la prueba y el derecho a la prueba en el proceso civil. In ABEL LLUCH Xavier y PICÓ JUNOY. Joan. Objeto y carga de la prueba civil. Barcelona: Bosch Editor, 2007.

ACEMOGLU, Daron.; ROBINSON, James. Porque as nações fracassam: as origens do poder, da prosperidade e da pobreza. Trad. Cristiana Serra. Rio de Janeiro: Elsevier, 2012.

ACKERMAN, Rose. The Economics of corruption. in Journal of Public Economics 4 (1975) fls. 187 a 203. North Holland Publishing Company. Disponível em: < https://gpde.direito.ufmg.br/wp-content/uploads/2019/08/rose-ackerman1975-1.pdf > Acesso em 12 mai 2020.

AGÊNCIA CÂMARA. Plenário retira tipificação do crime de enriquecimento ilícito do projeto anticorrupção. 30 nov 2016. Disponível em < https://www.camara.leg.br/noticias/503805-plenario-retira-tipificacao-do-crime-deenriquecimento-ilicito-do-projeto-anticorrupcao/ > acesso em 08 out 2020.

AGÊNCIA LUSA. Corrupção: os tentáculos da Odebrecht em Angola e Moçambique. Mai. 2017. Disponível em: < https://www.dw.com/pt002/corrup\%C3\%A7\%C3\%A3o-os-tent\%C3\%A1culos-da-odebrecht-em-angola-emo\%C3\%A7ambique/a-38569474> Acesso em 05 out 2020.

ALBERTO BRIOSHI, Carlos. Breve historia de la corrupción: de la antigüedad a nuestros días. Prólogo de Baltasar Garzón, Traducción de Juan Ramón Azaola. Madrid: Taurus, 2016.

ALBUQUERQUE, Marcelo Schirmer. A garantia de não auto-incriminação: extensão e limites. Belo Horizonte: Del Rey, 2008. 
ALFARO, Luis Humberto Contreras. Los delitos económicos relacionados con la corrupción: los principios de consenso y oportunidad en sede procesal penal, y la substitución del interés público en la persecución de la criminalidad de corrupción. Santiago do Chile: Editorial La Aurora. 2004.

ALVIM, Arruda. Manual de direito processual civil. 5.ed. São Paulo: Revista dos Tribunais, 1996, v. 2.

AMERICAN WARLIBRAR. Vítimas da Guerra do Vietnã por raça, etnia e origem nacional. Nov. 2008. Disponível em: <http://www.americanwarlibrary.com/vietnam/vwc10.htm> Acesso em 06 Out 2018.

ANNONI, Marco.; ILIOPULUS, Eleni. La corruzione costa. Effetti economici, istituzionali e sociali. Milano: Vita e Pensiero, 2005.

ANTUNES, Anderson. O custo da corrupção no Brasil pode chegar a US \$53 bilhões apenas neste ano. Nov. 2013. Disponível em: $<$ https://www.forbes.com/sites/andersonantunes/2013/11/28/the-cost-of-corruptionin-brazil-could-be-up-to-53-billion-just-this-year-alone/\#6bfa7dff4092> Acesso em 15 mai 2019.

ARMITAGE, John. Historia do Brazil. desde a chegada da Família Real de Bragança, em 1808 até a abdicação do Imperador D. Pedro I em 1831. Rio de Janeiro: Villeneuve e Comp, 1837 in. https://digital.bbm.usp.br/handle/bbm/4972.

ARNONE, Marco; BORLINI Leonardo S. Corruption: Economic Analysis and. International Law. Cheltenham, UK: Edward Elgar Publishing, 2014.

ASSIS, José Carlos de. A chave do tesouro. São Paulo: Paz e terra, 1983.

ÁVILA, Humberto. Teoria dos Princípios. $3^{\text {a }}$ Ed. São Paulo: Malheiros.

BACIGALUPO, Enrique. Presunción de inocencia, "in dubio pro reo" y recurso de casación. Sem data. Disponível no portal da Universidade de La Rioja em < https://dialnet.unirioja.es/servlet/articulo?codigo=46325 > acesso em 09 out 2020.

Estudios comparativos del derecho penal de los Estados Miembros de la Unión Europea sobre la represión del reciclaje o blanqueo de dinero ilícitamente obtenido. España en la Europa Comunitaria: Balance de diez años, 1995.

BADARÓ. Gustavo Henrique Righi Ivahy. O Crime de enriquecimento ilícito no projeto de código penal em face da presunção de inocência. Disponível em < http://www.badaroadvogados.com.br/21-082018-o-crime-de-enriquecimento-ilicitono-projeto-de-codigo-penal-em-face-da-presuncao-de-inocencia.html > acesso em 15 mar 2020.

BALBI, Giuliano. I delitti di corruzione: un indagine strutturale e sistematica. Napoli: Eugenio Jovene, 2003.

BARBAGALO, Fernando Brandini. Presunção de inocência e recursos criminais excepcionais: em busca da racionalidade no sistema processual penal brasileiro, 
recurso eletrônico. Brasília: TJDF. 2015. Livro eletrônico formato e-pub sem paginação.

BARBEIRO, Heródoto. A República Velha e o coronelismo: a verdadeira história do "é dando que se recebe". In: BIASON, Rita; LIVIANU, Roberto (Organizadores) A corrupção na história do Brasil. São Paulo: Mackenzie, 2019. Livro eletrônico formato e-pub não paginado.

BARBUGIANI, Luiz Henrique Sormani. A corrupção como fenômeno sociocultural: mecanismos de atenuação e contenção. In BARBUGIANI, Luiz Henrique Sormani (Coord.). Corrupção como fenômeno supralegal. Curitiba: Juruá, 2017.

BARCELOS, Andrea Beatriz Rodrigues de. Cooperação internacional para recuperação de ativos provenientes da lavagem de capitais. In. Revista Jurídica do Ministério Público do Estado de Minas Gerais. Disponível em: < .https://aplicacao.mpmg.mp.br/xmlui/bitstream/handle/123456789/313/coopera\%C3 \%A7ao\%20internacional_Barcellos.pdf?sequence=1> Acesso em 30 jun 2019.

BARROSO, Luís Roberto. O constitucionalismo democrático no Brasil: crônica de um sucesso imprevisto. Disponível em < http://www.luisrobertobarroso.com.br/wp-

content/uploads/2017/09/constitucionalismo_democratico_brasil_cronica_um_sucess o_imprevisto.pdf>. Acesso em 16.05.2020.

BATALHA, Elton Duarte e Prando, Rodrigo Augusto. A Arte de furtar: os portugueses e a exploração de riquezas. In: BIASON, Rita; LIVIANU, Roberto (Organizadores) A corrupção na história do Brasil. São Paulo: Mackenzie, 2019. Livro eletrônico formato e-pub não paginado.

BENSON, George Charles Summer. Political corruption in America. Lexington: Books, 1978.

BITENCOURT. Cezar Roberto. Direito penal das licitações. São Paulo: Saraiva, 2012.

BLANCO CORDERO, Isidoro Blanco. El delito de enriquecimiento ilícito desde la perspectiva europea. Revista Electrónica de la AIDP. 2013. A-02.

BLASI, Paulo Henrique. A ação civil pública como instrumento de combate à corrupção no estado democrático de direito. in Revista De Direito Administrativo. Vol. 221. jul/set 200. Rio de Janeiro: Renovar.

BLUTEAU. Raphael. Vocabulario portuguez, e latino, aulico, anatomico, architectonico, bellico, botânico." Coimbra: Collegio das Artes da Companhia de Jesus. 1712-1728. Disponível em: < https://www.bbm.usp.br/ptbr/dicionarios/vocabulario-portuguez-latino-aulico-anatomico-architectonico/ Acesso em 11 out 2019.

BOERSMA, Martine. Corruption: a violation of human rights and a crime under international law? Antwerp: Intersentia, 2012. 
BOND, Leticia. O poder legislativo custa $\mathbf{R} \$ 1,16$ milhão por ano, diz ONG. Jul. 2017. Disponível em: < http://agenciabrasil.ebc.com.br/politica/noticia/201707/poder-legislativo-custa-r-116-milhao-por-hora-diz-ong> Acesso em 02 mai 2019.

BORGES, Altamiro. Escândalos no governo FHC. Ago. 2020. Disponível em: <http://arnaldogodoy.com.br/casos-de-corrupcao-no-governo-fhc/> Acesso em 15. ago. 2020.

BORGES, José Souto Maior. Ciência feliz. São Paulo: Max Limonad, 2000.

BRASIL. Controladoria Geral da União. Portaria regulamenta programa da Controladoria Geral da União, em parceria com o Instituto Maurício de Sousa, que já envolveu $\mathbf{4 0 0}$ mil alunos, 13 mil professores e 1,6 mil escolas. Disponível em: < http://www.cgu.gov.br/assuntos/controle-social/educacao-cidada/um-portodos-e-todos-por-um-pela-etica-e-cidadania/um-por-todos-e-todos-por-um-1.> Acesso em 22 mar 2020.

BRASIL, Ministério da Economia. Relatório de Atividades do Conselho de Controle de Atividades Financeiras (COAF), relativo ao ano de 2018. Disponível em < http://www.fazenda.gov.br/orgaos/coaf/publicacoes/recentes/relatorio-deatividades-coaf-2018.pdf/view > Acesso em 08 out 2020.

Carga tributária. Disponível em: < http://www.fazenda.gov.br/centrais-deconteudos/publicacoes/carga-tributaria-liquida/carga-tributaria-liquida/ctl-2017.pdf:> Acesso em 01 mai 2020.

BRESSLER, Davi. Lava jato: AGU pede para EUA bloquear U\$D $124 \mathrm{mi}$ de empresa acusada de pagar propina. Disponível em: https://www.agu.gov.br/page/content/detail/id_conteudo/721421 .Acesso em 29 jun 2019.

BRISO, Caio Barreto; ROSSI, Marina. Prisão de Pezão retrata mais um capítulo de um Rio em decadência. 30.11.2018 in <https://brasil.elpais.com/brasil/2018/11/30/politica/1543533821_922616.html.> Acesso em 04.10.2020.

BRONZATTO, Thiago. Propinas da Odebrecht favoreceram poderosos de Angola e sobrinho de Lula. Disponível em: < https://veja.abril.com.br/politica/propinas-da-odebrecht-favoreceram-sobrinho-delula-e-poderosos-de-angola/> Acesso em 03 mai. 2020.

BUSTOS GISBERT. Rafael. La lucha contra la corrupción de los gobernantes: ¿un labor imposible? In RODRÍGUEZ GARCÍA, Nicolás.; FABIÁN CAPARRÓS, Eduardo A. Corrupción y delincuencia económica. Grupo Editorial lbañez. Bogotá, 2008.

CABRAL, José Santos. Prova indiciária e as novas formas de criminalidade. Intervenção no Centro de Formação Jurídica e Judiciária de Macau em 30 de novembro de 2011. Coimbra: Julgar n. 17. 2012.

CAIDEN, Gerald E. Toward a general theory of official corruption. Asian Journal of Public Administration, 10:1, 1988. 
CAMINHA, Pero vaz de. Carta a El Rey D. Manoel. Bahia: 1500. In $<$ http://objdigital.bn.br/acervo_digital/div_manuscritos/mss1277755/mss1277755.pdf. $>$ Acesso em 04. out 2020.

CARO CORIA, Dino Carlos. El delito de enriquecimiento ilícito. In SAN MARTIN CASTRO, César Eugenio.; CARO CORIA, Dino Carlos e LEANDRO PESHIERA, José. Los delitos de tráfico de influencias, enriquecimiento ilícito y asociación para delinquir. Aspectos sustantivos y procesales. Lima: Jurista Editores, 2002.

CARVALHO, Aurora Tomazini de. Curso de teoria geral do direito. São Paulo: Lumen Juris, 2019.

CARVALHO, Paulo Barros. Direito tributário: fundamentos jurídicos da incidência. $2^{a}$ ed. 1999, São Paulo: Atlas, 2015.

Direito tributário, linguagem e método. São Paulo: Noeses, 2008.

CARVALHOSA, Modesto. "Itamar Franco e a Comissão Especial de Investigações" In "BIASON, Rita; LIVIANU, Roberto (Organizadores) A corrupção na história do Brasil. Livro Eletrônico. São Paulo: Editora Mackenzie, 2019. Livro eletrônico formato e-pub não paginado.

CASARÕES, Guilherme. "A corrupção no governo Collor" in In "BIASON, Rita.; LIVIANU, Roberto (Organizadores) A corrupção na história do Brasil. Livro Eletrônico. São Paulo: Editora Mackenzie, 2019. Livro eletrônico formato e-pub não paginado.

CASTILLO, Diego Gomes. Whistleblowing. Una política eficaz en la recuperación de activos . in GÓMEZ DE LA TORRE, Ignácio Berdugo; FABIÁN CAPARRÓS, Eduardo A. (Directores) Recuperación de activos y decomiso: reflexiones desde los sistemas penales iberoamericanos. Valencia: Tirant Lo Blanch, 2017.

CASTRESANA FERNANDEZ, Carlos. La acción institucional y judicial contra la corrupción: Jornada sobre la corrupción en Espana, hoj. Situación y perspectivas. Barcelona, 2003, In: RODRÍGUEZ GARCÍA, Nicolás y FABIÁN CAPARRÓS, Eduardo A. (coord.) La corrupción en un mundo globalizado: análisis interdisciplinar. Salamanca: Ratio Legis. 2004.

CASTRO CUENCA, Carlos Guillermo. Corrupción y delitos contra la administración pública. especial referencia a los delitos cometidos en la contratacion. Coleción textos de jurisprudencia. Bogotá: Editorial Universidade del Rosario, 2009.

CEVALLOS Y TORRES, José Fernández de. Blanqueo de capitales y principio de lesividad. Madrid: Ratio Lelis, 2014.

CHAGAS, Paulo Victor. União autoriza estado do Rio a contrair empréstimo de R\$ 2,9 bilhões. $15 \quad$ dez $2017 . \quad$ in https://agenciabrasil.ebc.com.br/economia/noticia/2017-12/uniao-autoriza-estado-dorio-contrair-emprestimo-de-r-29-bilhoes. Acesso em 04.10.2020. 
CORTÉS DOMINGUEZ, Valentin.; MORENO CATENA, Víctor. Derecho procesal civil. 10 Ed. Valencia: Tirant Lo Blanch, 2019.

COSSIO, Carlos. La teoría egológica del derecho. Buenos Aires: Losada, 1954.

COULON, Maria de los Ángeles González. La carga dinámica de prueba y sus límites. En especial el límite impuesto por la no autoincriminación. Santiago: Thompson Reuters, 2013.

COUTINHO, Alessandro Dantas e RODOR, Ronald Kruger. Manual de direito administrativo. Rio de Janeiro: Forense. 2015.

COUTURE, Eduardo J. Fundamentos del derecho procesal civil. Buenos Aires: Depalma, 1974.

CRISÓSTOMO, São João. Comentário às cartas de São Paulo. Ed. Paulus, arquivo eletrônico. Disponível em: < https://catolicotridentino.files.wordpress.com/2017/11/patrc3adstica-vol-27_3comentc3a1rio-as-cartas-de-sao-paulo-sao-joao-crisc3b3stomo.pdf> Acesso em 3 jul 2020.

DALLAGNOL, Deltan Martinazzo. As lógicas das provas no processo: prova direta, indícios e presunções. São Paulo: Livraria Do Advogado, 2015.

DALLAGNOL, Deltan Martinazzo; COELHO, Walter. Prova Indiciária em matéria criminal. Porto Alegre: Fundação Escola Superior do Ministério Público: 1996.

DEL TESO, Ana E. Carrillo. La recuperación de activos como estrategia común contra la criminalidad. In GÓMEZ DE LA TORRE, Ignácio Berdugo.; FABIÁN CAPARRÓS, Eduardo A (Directores). Recuperación de activos y decomiso: reflexiones desde los sistemas penales iberoamericanos. Valencia: Tirant Lo Blanch, 2017.

DELLA PORTA, Donatella e VANNUCCI, Alberto. A typology of corrupt networks. In KAWATA, Junichi. (Editor) Comparing Political Corruption and clientelism. Hampshire: Ashgate, 2000.

DELLEPIANTE, Antonio. Nova Teoria da prova. 7 Ed. trad. Erico Maciel. Campinas: Minelli, 2004.

DENNIS, lan. The law of evidence. London: Sweet \& Maxwell, 2007.

DIONÍSIO, Bibiana. Corrupção pode chegar a $20 \%$ dos contratos da Petrobras, diz delegado. G1. PR. Jul. 2015. Disponível em: <http://g1.globo.com/pr/parana/noticia/2015/07/corrupcao-pode-chegar-20-doscontratos-da-petrobras-diz-delegado.html> Acesso em 15 set 2018.

DONDOSSOLA, Edivaldo, FREIRE, Felipe, COELHO, Henrique e MARTINS, Marco Antônio. Força-tarefa prende 15 em operação contra fraudes em cartórios do RJ in https://g1.globo.com/rj/rio-de-janeiro/noticia/2019/02/28/forca-tarefa-fazoperacao-para-prender-quadrilha-suspeita-de-praticar-fraudes-em-cartorios-dabaixada-fluminense.ghtml. Acesso em 13 set 2019. 
DOS SANTOS, Leonardo Augusto de Andrade Cezar. Compliance e partidos políticos: novo modelo para o combate à corrupção e da captura do Estado. In: BARBUGIANI, Luiz Henrique Sormani (Coord.). Corrupção como fenômeno supralegal. Curitiba: Juruá, 2017.

DYE, Kenneth M.; STAPENHURST, Rick. Pillars of integrity: the importance os supreme audit institutions in curbing corruption. Economic Development Institute of the Word Bank. EDI Working Papers. Disponível em: < http://www1.worldbank.org/publicsector/pe/JanSeminar/Course\%20Readings/09.\%2 0External\%20Accountability/Pillars\%20of\%20Integrity.pdf> Acesso em 24 mai 2020.

EL PAíS. Mr. Trust, Eduardo Cunha como símbolo do combate à corrupção. Chamado de senhor do trust, deputado cassado é alvo de campanha da transparência internacional. Mai. 2019. Disponível em: <https://brasil.elpais.com/brasil/2016/09/13/politica/1473800752_448764.html> Acesso em 12 set 2019.

ESTADO DE SÃO PAULO. Kadafi abasteceu companhia de Lula com USS 1 milhão, de acordo com Palloci. Dez. 2017. Disponível em: $<$ https://politica.estadao.com.br/noticias/geral,kadafi-abasteceu-campanha-de-lulacom-us-1-milhao-diz-palocci,70002112919>. Acesso em 11 set 2019.

FABIÁN CAPARRÓS, Eduardo A. La corrupción de agente publico extranjero e internacional. Valencia: Tirant lo Blanch, 2003.

. La corrupción de los servidores públicos extranjeros e internacionales (anotaciones para un derecho penal globalizado) in RODRIGUEZ GARCÍA, Nicolás.; FABIÁN CAPARRÓS, Eduardo (coord.) La Corrupción en un Mundo Globalizado: análisis Interdisciplinar. Salamanca: Ratio Legis, 2004.

. La regulación del decomisso tras la reforma de la ley orgánica 1/2015. in GÓMEZ DE LA TORRE, Ignácio Berdugo; CAPARRÓS, FABIÁN CAPARRÓS, Eduardo A (Directores) Recuperación de activos y decomiso: reflexiones desde los sistemas penales iberoamericanos. Valencia: Tirant Lo Blanch, 2017.

FABIÁN CAPARRÓS, Eduardo; RODRÍGUEZ GARCÍA, Nicolás. Lavagem de capitais e sistema penal: contribuições hispano-brasileiras a questões controvertidas. Porto Alegre: Verbo Jurídico, 2014.

FALCÓN, Enrique. Tratado de la prueba. v. 1. Buenos Aires: Astrea, 2003.

FEITOZA, Denílson. Direito processual penal: teoria, crítica e práxis. $7^{\text {a }}$ Ed. Rev., ampl. e atual. Rio de Janeiro: Impetus, 2010.

FERNÁNDEZ MORA, Chrístian. O ordenamento jurídico da Costa Rica ante a criminalidade dos poderosos: uma análise sobre a corrupção na função pública. In BARBUGIANI, Luiz Henrique Sormani. (Coord.) Corrupção como fenômeno supralegal. Curitiba: Juruá, 2017.

FERRAGUT, Maria Rita. Presunções no direito tributário. São Paulo: Dialética, 2001. 
FERRARO, Alceu Ravanello.; KREIDLOW, Daniel. Analfabetismo no Brasil: configuração e gênese das desigualdades regionais. Disponível em: <

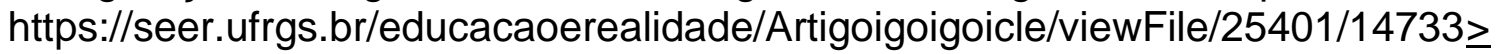
Acesso em 5 mar 2019.

FERRAZ JUNIOR, Tercio Sampaio. Introdução ao estado do direito. São Paulo: Atlas, 2019.

FERREIRA, João Henrique. Indícios, presunções e ficções no direito penal: aspectos principais. Dissertação de mestrado apresentada perante a PUC SP. São Paulo: $\quad$ PUC, 2006.2 Disponível em < http://www.dominiopublico.gov.br/download/teste/arqs/cp009410.pdf > acesso em 09 out 2020.

FERRER BELTRÁN, Jordi. La valoración racional de la prueba. Madrid: Marcial Pons, 2007.

FREIRE, Marcelo. Conheça $\mathbf{1 0}$ histórias de corrupção durante a ditadura militar. Abr 2015. Disponível em: <https://noticias.uol.com.br/politica/ultimasnoticias/2015/04/01/conheca-dez-historias-de-corrupcao-durante-a-ditaduramilitar.htm> Acesso em 23 mai 2019.

FRIDRICZEWSKI, Vanir. Estado Democrático de Direito e corrupção pública: de que fenômeno está tratando. In Barbugiani, Luiz Henrique Sormani. (Coord.) Corrupção como fenômeno supralegal. Curitiba: Juruá, 2017.

FRIEDRICH, Carl J. The pathology of politics: violence, betrayal corruption, secrecy and propaganda. New York: Harper \& row, 1972, p. 127-141. In HEIDENHEIMER, Arnold J. and JOHNSTON, Michael (org) Political corruption. 3.ed. New York: Routledge, 2017.

GAMA LEYVA, Raymundo. La cadena de custodia en el caso Puebla y la importancia del razonamiento probatorio. Diciembre 13. 2018. Disponível em < https://eljuegodelacorte.nexos.com. $m x / ? p=9375>$ acesso em 09 out 2020. Documento eletrônico não paginado.

Las presunciones en el derecho: entre la perplejidad y la fascinación de los juristas. Espanha: Tirant lo Blanch, 2019.

GARCíA, Oscar Morales. Los delitos de malversación. Apropiación, utilización temporal y administración desleal de caudales públicos. Navarra: Aranzadi Editorial.

GASPARI, Elio. A ditadura derrotada. o sacerdote e o feiticeiro. Rio de Janeiro: Intrínseca, 2014. Livro eletrônico formato e-pub não paginado.

A ditadura escancarada. as ilusões armadas. $2^{\mathrm{a}}$ Ed. Rio de Janeiro: Intrínseca, 2014a. Livro eletrônico formato e-pub não paginado.

GHIZZO Neto, Affonso. Adhemar de Barros: rouba, mas faz. In: BIASON, Rita; LIVIANU, Roberto (Organizadores) A corrupção na história do Brasil. São Paulo: Mackenzie, 2019. Livro eletrônico formato e-pub não paginado. 
GOMES FILHO, Antônio Magalhães. Notas sobre a terminologia da prova (reflexos no processo penal brasileiro). In YARSHELL, Flávio Luiz.; MORAES, Mauricio Zanoide (org) Estudos em homenagem à Professora Ada Pellegrini Grinover. São Paulo: DPJ, 2005.

GOMES, Ana Cristina.; FERNANDES, Fernando Antônio. A corrupção como violadora de direitos humanos: como a corrupção pode macular direitos sociais e desvirtuar políticas públicas. Cadernos Prolam/USP, São Paulo: jul./dez .2017, v.16, n.31.

GOMES, Laurentino. 1889. como um imperador cansado, um marechal vaidoso e um professor injustiçado contribuíram para o fim da monarquia e a proclamação da república no Brasil. São Paulo: Globo, 2013, Livro eletrônico formato e-pub não paginado.

1808: como uma rainha louca, um príncipe medroso e uma corte corrupta enganaram Napoleão e mudaram a História de Portugal e do Brasil. $3^{\underline{a}}$ ed. São Paulo: Globo, 2014. Livro eletrônico formato e-pub não paginado.

.1822: Como um homem sábio, uma princesa triste e um escocês louco por dinheiro ajudaram dom Pedro a criar o Brasil - um país que tinha tudo para dar errado. São Paulo: Globo, 2015, Livro eletrônico formato e-pub não paginado.

GOMES, Luiz Flavio. Princípio da não autoincriminação: significado, conteúdo, base jurídica e âmbito de incidência. Disponível em: https://ff.jusbrasil.com.br/noticias/2066298/principio-da-nao-auto-incriminacaosignificado-conteudo-base-juridica-e-ambito-de-incidencia Acesso em 14 abr 2020.

GÓMEZ DE LA TORRE, Ignácio Berdugo. Política criminal contra la corrupción: La reforma del decomiso en España. in GÓMEZ DE LA TORRE, Ignácio Berdugo; FABIÁN CAPARRÓS, Eduardo A (Directores) Recuperación de activos y decomiso: reflexiones desde los sistemas penales iberoamericanos. Valencia: Tirant Lo Blanch, 2017.

GONZÁLEZ-CASTELL, Adán Carrizo. Investigación Policial y recuperación de activos procedentes de la corrupción y el crimen organizado in GÓMEZ DE LA TORRE, Ignácio Berdugo; FABIÁN CAPARRÓs, Eduardo A. (Directores) Recuperación de activos y decomiso: reflexiones desde los sistemas penales iberoamericanos. Valencia: Tirant Lo Blanch, 201.

HARET, Florece. Por um conceito de presunção. Revista da Faculdade de Direito de São Paulo. Universidade de São Paulo, v. jan/dez, 2009.

HASSEMER, Winfried. Sistema jurídico y codificación: la vinculación del juez a la ley. Trad. De MARTINEZ BRETONES María Virgínia. In HASSEMER, Winfried. EI pensamiento jurídico contemporáneo. Madrid: Debate, 1992.

HEGENBERG, Leônidas. Saber de e saber que: alicerces da racionalidade. Rio de Janeiro: Vozes, 2001. 
HEIDENHEIMER, Arnold J. Perspectives of the perception of corruption In: HEIDENHEIMER, Arnold J. and JOHNSTON, Michael (org) Political Corruption: Concepts and Contexts 3.ed. Routledge, New York, 2017.

HELMHOLZ, Richard. $\mathrm{H}$. et al. The privilege against self-incrimination: its origins and development. Chicago: The University of Chicago Press, 1997.

HENDERSON, James. A history of the Brazil: comprising its geography, commerce, colonization, aboriginal inhabitants. Londres: Longman, Hurst, Rees, Orme, and Brown, 1821. Disponível em < in https://www2.senado.leg.br/bdsf/handle/id/518715. Acesso em 13. jun. 2019.

HOBBES, Thomas. Do cidadão. São Paulo: Martins Fontes, 1998.

HOETJES, Bernard, J. S. Nature, extent and reality of the phenomenon of corruption in the public service. in Corrupption de fonctionnarires et fraude européenne. Antwerpen: Maklu Uitgevers, 1998.

HOLANDA, José llo Rogério de. O impacto da corrupção na economia dos países. In BARBUGIANI, Luiz Henrique Sormani. (Coord.) Corrupção como fenômeno supralegal. Curitiba: Juruá, 2017.

HORTA, Maurício. Mito: na época da ditadura militar, não tinha corrupção. Set. 2018. Disponível em: <https://super.abril.com.br/historia/mito-na-epoca-da-ditaduramilitar-nao-tinha-corrupcao/> Acesso em 13. jun. 2019.

HOUAISS, Antônio. Dicionário de sinônimos a antônimos da língua portuguesa. Rio de Janeiro: Objetiva.

INSTITUTO BRASILEIRO DE GEOGRAFIA E ESTÁTICA (IBGE). Condições de vida, desigualdades e pobreza. Disponível em: https://www.ibge.gov.br/estatisticas/multidominio/condicoes-de-vida-desigualdade-epobreza.html> Acesso em 20 abr 2020.

INSTITUTO DE PESQUISA ECONÔMICA APLICADA (IPEA). 2020. V.2.6.4 .Atlas do estado brasileiro. Disponível em: <http://www.ipea.gov.br/atlasestado> Acesso em 08 out 2020. Livro eletrônico formato eletrônico não paginado.

INSTITUTO DE PESQUISA ECONÔMICA APLICADA (IPEA). Atlas da violência. 2020. Disponível em: https://www.ipea.gov.br/atlasviolencia/ Acesso em 04 Out 2020.

IRIARTE, Gustavo Cuello. Derecho probatório y pruebas penales. Bogotá: Legis, 2008.

JIMÉNEZ FRANCO, Emmanuel. La oficina de recuperación y gestión de activos (ORGA) de España: Origen, presente y futuro. in GÓMEZ DE LA TORRE, Ignácio Berdugo; FABIÁN CAPARRÓS, Eduardo A. (Directores) Recuperación de activos y decomiso: reflexiones desde los sistemas penales iberoamericanos. Valencia: Tirant Lo Blanch, 2017.

KELSEN, Hans. Teoria pura do direito. $2^{\mathrm{a}}$ ed. São Paulo: Martins Fontes, 1987. 
KNIJNIK, Danilo. Os standards do convencimento judicial: paradigmas para o seu possível controle. Revista Forense, Rio de Janeiro, n. 353, p. 15-52, jan.-fev. 2001.

LEOPOLDO, Ricardo. Brasil perde cerca de $\mathbf{R} \$ 200$ bilhões por ano com corrupção. Fev. 2017. Disponível em: <<https://istoe.com.br/brasil-perde-cerca-de-r200-bilhoes-por-ano-com-corrupcao-diz-mpf/>. Acesso em 27 set.2018.

LINDLEY, Thomas. Narrativa de uma viagem ao Brasil. Trad. Thomaz Newlands Neto. São Paulo: Companhia Editora Nacional, 1969.

LÓPES ESPINOZA, Reiser.; NOLASCO VALENZUELA, José.; e AYALA MIRANDA, Erika. Manual de litigación em Prueba Indiciaria. Los estándares Fijados por la Corte Suprema y el Tribunal Constitucional. Lima: Ara editores, 2011.

LOPES JR. Aury e ROSA, Alexandre Morais da. Sobre o uso do standard probatório no processo penal. Disponível em: < https://www.conjur.com.br/2019jul-26/limite-penal-uso-standard-probatorio-processo-penal.> Acesso em 11 fev 2020.

LOPES JR. Aury. Réu não deve ser obrigado a provar causa de exclusão da ilicitude Disponível em < https://www.conjur.com.br/2015-ago-14/limite-penal-reunao-obrigado-provar-causa-exclusao-ilicitude > acesso em 09 out 2020.

LOPES, Elizabeht.; AFFONSO, Julia. Corrupção desvia R\$ 200 bi, por ano, no Brasil, diz coordenador da Lava Jato. Set. 2015. Disponível em: $<$ https://politica.estadao.com.br/blogs/fausto-macedo/corrupcao-desvia-r-200-bi-porano-no-brasil-diz-coordenador-da-lava-jato/;

https://exame.abril.com.br/brasil/corrupcao-tira-r-200-bi-ao-ano-dos-cofres-dizprocurador/> Acesso em 15 mai 2019.

LOPEZ MORENO, Santiago. La prueba por indicios. Madrid: Imprenta de A J. Alaria, 1879. Disponível no acervo virtual da Biblioteca de Sevilla em < https://fama.us.es/discovery/search?vid=34CBUA_US:VU1 > acesso em 09 out 2020.

LOPEZ RAMÍREZ, Antônio López. La presunción de inocencia y el principio de culpabilidad en el sistema acusatorio. Mexico, Ubijus. 2012.

MALATESTA, Nicola Framarino dei. A lógica das provas em matéria criminal. Com um prefácio do Prof. Emilio Brusa. Tradução de J. Alves de Sá. 2ª Ed. Lisboa, Livraria Clássica, 1927.

MALUF, Carlos Alberto Dabus. As presunções na teoria da prova. Revista da Faculdade de Direito, Universidade de São Paulo, n 79, 1986.

MANTAIA, Carla Aparecida. Obrigação tributária e seus aspectos legais. ago. 2016. disponível em: < https://ambitojuridico.com.br/cadernos/direitotributario/obrigacao-tributaria-e-seus-aspectos-legais/ > Acesso em 2 fev 2020. 
MARTÍNEZ, José Joaquin Urbano. La nueva estrutura probatória del processo penal: hacia una propuesta de fundamentación del sistema acusatorio. Bogotá: Nueva jurídica, 2011.

MELLO, Celso Antônio Bandeira de. Conteúdo jurídico do princípio da igualdade. $3^{\text {a }}$ ed. São Paulo: Malheiros, 2007.

MENDES, Gilmar Ferreira. Direitos fundamentais e controle de constitucionalidade: estudos de direito constitucional. 3. Ed. São Paulo: Saraiva, 2009.

MENDONÇA, Christine. A não cumulatividade do ICMS. São Paulo, Quartier Latin: 2005.

MIRANDA, Franciso Cavalcanti Pontes de. Tratado de direito privado: parte geral. 2. Ed. Rio de Janeiro: Borsoi, 1954.

MITTERMAIER, Carl Joseph Anton Tratado de la prueba en materia criminal. Madrid: Reus, 1979.

MONTAÑES PARDO, Miguel Angel. La presunción de inocencia. Aranzadi: Editorial, 1999. MORANO, Anthony A. A reexamination of the development of the reasonable doubt rule. 55 Boston Universtity Law Review. 507 (1975) versão electronica em https://heinonline.org/HOL/LandingPage?handle=hein.journals/bulr55\&div=31\&id=\&p age $=$ acesso em 09 out 2020 .

MORO, Sergio Fernando. Crime de lavagem de dinheiro. São Paulo: Saraiva, 2010.

MOROFF, Holger e BLECHINGER, Verena. Corruption terms in wordpress: how languages differ. In. HEIDENHEIMER, Arnold J. and JOHNSTON, Michael (org) Political Corruption: Concepts and Contexts. New York: Routledge, 2017.

MOURA, Cid Capobiango Soares. Aspectos relevantes sobre a improbidade administrativa, Lei 8.429/92. Disponível em: < https://ambitojuridico.com.br/cadernos/direito-administrativo/aspectos-relevantessobre-a-improbidade-administrativa-lei-8-429-92/ > Acesso em 24 dez 2019.

MOURA, Denise Aparecida Soares de. Jogo de acusações: denúncias de mau governo e competição de interesses na América Latina. In: BIASON, Rita; LIVIANU, Roberto (Organizadores) A corrupção na história do Brasil. São Paulo: Mackenzie, 2019. Livro eletrônico formato e-pub não paginado.

MOURA, Maria Thereza Rocha de Assis. A prova por indícios no processo penal. Reimpressão. Rio de Janeiro: Lumen juris. 2009.

MOUSSALEM, Tárek Moysés. Fontes do direito tributário. São Paulo: Max Limonad, 2000.

MUNGIU-PIPPIDI, Alina. The quest for good governance. How societies develop control of corruption. Cambridge: University Press, 2001. 
MURIEL PATINO, María Victoria. El fenómeno de la corrupción: consideraciones desde la macroeconomía. In RODRíGUEZ GARCÍA, Nicolás.; FABIÁN CAPARRÓS, Eduardo A (coordenadores). Corrupción y delincuencia económica. Bogotá: Grupo Editorial Ibañez, 2008.

NAVA GARCÉS, Alberto Enrique. La prueba electrónica en materia penal. Nuevas tecnologías de la información, redes sociales, telefonía celular, dispositivos electrónicos, geolocalización, cadena de custodia, prueba ilícita. Casos. Ciudad de Mexico: Porrúa, 2015.

NERI, Marcos. A escalada da desigualdade: qual foi o impacto da crise sobre a distribuição de renda e pobreza?. Disponível em: < https://www.cps.fgv.br/cps/bd/docs/RESUMO-A-Escalada-da-Desigualdade-MarceloNeri-FGV-Social-com-posfacio.pdf in https://cps.fgv.br/desigualdade.> Acesso em 03 mar 2020.

NEVADO-BATALHA MORENO, Pedro Tomás. Calidad de los servicios. In. Revista Estudios Socio-Jurídicos. Bogotá: 2003, enero-junio, v. 5 n. 1.

Responsabilidad dos servidores públicos: Rendimiento como garantía a la legalidad de la actuación pública, 2015.

Reflexiones sobre una posible etiología de las malas prácticas y la corrupción en el ámbito de las administraciones públicas. In ROMERO GUZMÁN, Juan José, RODRÍGUEZ GARCÍA, Nicolás y OLIVARES TRAMÓN, José Miguel (editores) Buen Gobierno y Corrupción. Algunas perspectivas. Santiago de Chile: Pontificia Universidad Católica de Chile, Ediciones Derecho UC, 2009.

NYE, J. S. Corruption and political development: A cost benefit analysis. In HEIDENHEIMER, Arnold J.; Johnston, Michael (org) Political Corruption: Concepts and Contexts 3.ed. New York: Routledge, 2017.

OLIVEIRA, Júlio Marcelo de.; LIVIANU, Roberto. Lula e os recursos públicos: o mensalão. In: BIASON, Rita.; LIVIANU, Roberto (Organizadores). A corrupção na história do Brasil. São Paulo: Mackenzie, 2019. Livro eletrônico formato e-pub não paginado.

ONOFRE, Renato. PF encontra cofre com presentes ganhados por lula na presidência. Jun. 2016. Disponível em: <https://oglobo.globo.com/brasil/pfencontra-cofre-com-presentes-ganhados-por-lula-na-presidencia-18858459> Acesso em 11 set 2019

ORGANIZAÇÕES DAS NAÇÕES UNIDAS (ONU) Acidentes de trânsito matam 1,25 milhão de pessoas no mundo por ano. Jan. 2008. Disponível em: $<$ https://nacoesunidas.org/acidentes-de-transito-matam-125-milhao-de-pessoas-nomundo-por-ano/>. Acesso em 06 jan 2020.

ORMAZABAL SÁNCHEZ, Guillermo. Carga de la prueba y sociedade de riesgo. Madrid: Marcial Pons, 2004.

ORTEGO PÉREZ, Francisco. La delimitación entre el principio in dubio pro reo y la presunción de inocencia en el proceso penal español: the distinction between 
the beginning in dubio pro reo and the presumption of innocence in spanish criminal procedure. Revista chilena de derecho y ciencia política, septiembre- Diciembre, 4(3) p. 11-30, 2013.

ORTOLAN, Louis Elzear. Explicación histórica de las instituciones del emperador Justiniano, con el texto latino, la traducción al lado y las explicaciones a continuación de cada párrafo (...) Trad. De D. Francisco Perez de Anaya. Madrid: Estabelecimiento Gráfico de D. Ramon Rodriguez de Rivera. 1847. Versão eletrônica disponível em < https://books.google.fm/books?id=h2aHswEACAAJ\&pg=PA101\&hl=pt-

BR\&source=gbs_toc_r\&cad=3\#v=onepage\&q\&f $>$ acesso em 08 out 2020 .

OVEJERO PUENTE, Ana Maria. Constitución y derecho a la presunción de inocencia. Valencia: Tirant lo Blanch, 2006.

PABÓN GÓMEZ, Germán. Lógica del indicio en materia criminal. Tomo I. 3 Ed. Bogotá: Ibañez, 2007.

PANDOLFO, Rafael. In dubio pro reo e sua aplicabilidade às sanções tributárias. Disponível em: < https://www.ibet.com.br/wpcontent/uploads/2014/01/Rafael-Pandolfo.pdf> Acesso em 20 abr. 2020.

PATRÍCIO, Rui. O princípio da presunção de inocência do arguido na fase do julgamento do actual processo penal português: Alguns problemas e esboço para uma reforma do processo penal português. Lisboa: Associação Academia da faculdade da direito de Lisboa, 2004.

PEDRUZZI. Pedro. Operação da PF investiga corrupção em cartório de imóveis na Bahia. Disponível em: < http://agenciabrasil.ebc.com.br/geral/noticia/201804/operacao-da-pf-investiga-corrupcao-em-cArtigoigoigoorio-de-imoveis-na-bahia. .> Acesso em 13 set 2019.

PEIRCE, Charles Sanders. Escritos filosóficos. primer volumen. Zamora: Colegio de Michoacán, 1997.

.What is a sign? In. The essential peirce: selected philosophical writings. Peirce Edition Project. Indiana: Indiana University Press.

PÉREZ BARBERÁ, Gabriel e BOUVIER, Hernán. Cassación, lógica yu valoración de la prueba. Un análisis de la argumentación sobre hechos en las sentencias de los tribunales casatorios. In REYNA ALFARO, Luis Miguel. La prueba, reforma del proceso penal y derechos fundamentales. Lima, Juristas Editores, 2007.

PICHLER, Pablo Andrés Rojas. La función de la responsabilidad civil ex delito como herramienta de recuperación de activos ilícitos y de prevención con respecto a los delitos de corrupción pública. in GÓMEZ DE LA TORRE, Ignácio Berdugo; FABIÁN CAPARRÓS, Eduardo A (Directores). Recuperación de activos y decomiso: reflexiones desde los sistemas penales iberoamericanos. 2017. Valencia: Tirant Lo Blanch.

Tratamiento jurídico penal de los incrementos patrimoniales injustificados en la función pública - el delito de enriquecimiento ilícito en la 
legislación paraguaya y su problemática dogmática-constitucional. Tese de doutorado apresentada na Universidade de Salamanca. 2013. inédita.

PINHEIRO, Ricardo Miranda e DELGADO, Dicson. Enriquecimento ilícito praticado por policial militar: análise da doação de refeições durante o policiamento inédito, apresentado como requisito parcial para aprovação na disciplina Responsabilidade Civil e Penal do Administrador Público" no Curso de Aperfeiçoamento de Oficiais da Polícia Militar- CAO, promovido pela Academia da Polícia Militar do Estado do Espírito Santo.

PINTO, Luís Maria da Silva. Dicionário da língua brasileira. Ouro Preto, Typographia de Silva, 1832. Disponível: em: < https://www.bbm.usp.br/ptbr/dicionarios/diccionario-da-lingua-brasiLeira/ acesso > Acesso em 11 out 2019.

PINTO, Virgílio Noya. O ouro Brasileiro e o comércio anglo-português: uma contribuição aos estudos da economia atlântica do século XVIII. São Paulo: Nacional, 1979.

POPE, Jeremy. Confronting Corruption: the elements of a national integrity system. Transparency International. TI Source Book 2000. Disponível em < https://www.transparency.org.nz/docs/2000/Elements-of-a-National-Integrity-

System.pdf > acesso em 08 out 2020.

PORTO CARREIRO, P J. Psicologia judiciária. Rio de Janeiro: Kogan, 1932.

PRAZERES, Leandro. Corrupção nos quartéis. Disponível em: < https://www.uol/noticias/especiais/corrupcao-nos-quarteis.htm\#corrupcao-nosquarteis > Acesso em 13 set 2019.

QUAH, Jon S. T. Response to corruption in Asian Societies. In Heidenheimer, Arnold J. and Johnston, Michael (org) Political Corruption: Concepts and Contexts. 3.ed. Routledge: New York, 2017.

QUEIROZ, João. Classificação de signos de C.S. Peirce: 'on the logic of the science' ao 'syllabus of certain topic of logic'. Marília: 2007. Disponível em: < http://www.scielo.br/pdf/trans/v30n2/a12v30n2.pdf,> Acesso em 09 out 2020. Documento eletrônico não paginado.

QUIJANO, Jairo Parra. Tratado de la prueba judicial. Indicios y presunciones. Tomo IV, 7 Ed. Bogotá: Llibrería Ediciones del profesional Ltda, 2014.

RAMOS, Baudilio Murcia. El enriquecimiento ilícito y la extinción de dominio. Bogotá: Ibañes, 2012.

RAPOZA, Kennet. Quando se trata de empresas estatais, o Brasil é a China da América Latina. Nov. 2018 Disponível em: $<$ https://www.forbes.com/sites/kenrapoza/2018/11/03/when-it-comes-to-state-ownedcompanies-brazil-is-the-china-of-latin-america/\#6beea7a753da> Acesso em 14 mai 2019.

RENAUX, Pedro. Pobreza aumenta e atinge $54,8 \%$ de pessoas no mundo por ano. Jan. 2018. Disponível em: <https://agenciadenoticias.ibge.gov.br/agencia- 
noticias/2012-agencia-de-noticias/noticias/23299-pobreza-aumenta-e-atinge-54-8milhoes-de-pessoas-em-2017> Acesso em 12 jun 2019.

RENZ, Patrick S. Project governance. Implementing corporate governance and business ethics in nonprofit organizations. Heildelberg: Physica Verlag, A Springer Company, 2007.

RIBEIRO, Isolda Lins. Patrimonialismo e personalismo: a gênese das práticas de corrupção no Brasil. Anais do XIX Encontro Nacional do Conselho Nacional de Pesquisa e Pós Graduação em Direito - CONPEDI realizado em Fortaleza, CE nos dias 09, 10, 11 e 12 de Julho de 2010. Fls. 8415. Disponível em: $<$ http://www.publicadireito.com.br/conpedi/manaus/arquivos/anais/fortaleza/3324.pdf $>$ Acesso em 03 jun 2019.

RITCHER, André. AGU, reforçará grupo que atua no combate à corrupção. Abr. 2019. Disponível em: < https://www.agu.gov.br/page/content/detail/id_conteudo/734418.> Acesso em 29 jun 2019.

ROBLES, Gregório. As regras do direito e as regras dos jogos: ensaio sobre a teoria analítica do direito. Trad. Pollyana Mayer. São Paulo: Noesis. 2011.

RODAS, Sergio. Desvios na Eletronuclear: Bretas aceita duas denúncias, e Temer vira réu por corrupção, peculato e lavagem. 02 abr.2019 disponível em < https://www.conjur.com.br/2019-abr-02/michel-temer-vira-reu-corrupcao-peculatolavagem-dinheiro $>$. Acesso em 04 out 2020.

RODRIGUES, Marcelo Abelha. Manual de direito processual civil. 5aㅡ. Ed., São Paulo: LRT, 2010.

RODRÍGUEZ GARCÍA, Nicolás. Cooperación judicial Internacional y la lucha contra la corrupción. Algunas experiencias orgánicas en la Unión Europea. In ROMERO GUZMAN, Juan José, RODRÍGUEZ GARCÍA, Nicolás y OLIVARES TRAMÓN, José Miguel (editores) Buen Gobierno y Corrupción. Algunas perspectivas. Santiago de Chile: Pontificia Universidad Católica de Chile, Ediciones Derecho UC, 2009.

Corrupción, estado de derecho y poder judicial: retos y límites de las iniciativas supranacionales e internacionales de asistencia y cooperación judicial penal. In: GÓMEZ, De La Torre.; IGNÁCIO, Berdugo.; BECHARA, Ana Elisa Libertadore S. Bechara (Coordinadores) Estudios sobre la corrupción: una reflexión hispano brasileña. Salamanca: Centro de Estudios Brasileños, 2013.

.Epílogo: La creación de una fiscalía anticorrupción en el espacio europeo de Justicia: la historia de un sueño que debiera hacerse realidad. In RODRÍGUEZ GARCÍA, Nicolás e ORSI, Omar G. (editores) El ministerio fiscal en el combate a la corrupción: experiencias y perspectivas desde los sistemas penales de iberoamérica. Ciuidad de Mexico: UBIJUS, 2014.

. La creación de un espacio judicial europeo penal: aportes de los mecanismos de organización y coordinación de la cooperación judicial. Justitia: diciembre 2011. 
. Nicolás. La necesaria flexibilización del concepto de soberanía en pro del control judicial de la corrupción. in RODRÍGUEZ GARCÍA, Nicolás y FABIÁN CAPARRÓS, Eduardo A. (coord.) La corrupción en un mundo globalizado: análisis interdisciplinar. Salamanca: Ratio Legis, 2004.

Redescubrimiento de las bonanzas del decomiso en las tácticas supranacionales e internacionales para poner freno a la "sociedad incivil". in GÓMEZ DE LA TORRE, Ignácio Berdugo; FABIÁN CAPARRÓS, Eduardo A. (Directores) Recuperación de activos y decomiso: reflexiones desde los sistemas penales iberoamericanos. Valencia: Tirant Lo Blanch, 2011.

RODRÍGUEZ GARCÍA, Nicolás.; GABRIEL ORSI, Omar. El delito de enriquecimiento ilícito en américa latina: tendencias y perspectivas in. Cuadernos de Politica Criminal. Segunda Época. Num. 116, Septiembre 2015. p 201-260.

RODRíGUEZ GARCíA, Nicolás.; PÉREZ-CRUZ MARTíN, Agustín-Jesús. Regulación del derecho a un proceso penal sin dilaciones indebidas: de la atenuante analógica a la atenuante específica del código penal. Anuário da Faculdade de Direito da Universidade da Coruña, 2011.

RODRÍGUEZ GOMEZ, Carmen. Corrupción en la administración pública: aspectos penales. In. RODRÍGUEZ GARCÍA, Nicolás e FABIÁN CAPARRÓS, Eduardo A. Corrupción y delincuencia económica. Grupo Editorial Ibañez. Bogotá, 2008.

RODRÍGUEZ LÓPEZ Fernando. El conflito entre proporcionalidade y eficácia en las sanciones por corrupción. In RODRÍGUEZ GARCÍA, Nicolás.; FABIÁN CAPARRÓS, Eduardo A. Corrupción y delincuencia económica. Bogotá: Grupo Editorial Ibañez. 2008.

Introducción al análisis económico de la corrupción. In FABIÁN CAPARRÓS, Eduardo A. (coord.). La corrupción: aspectos jurídicos y económicos. Madrid: Ratio Legis. 2000.

. Puede el derecho sancionador frenar la corrupción? Reflexiones desde el análisis económico del derecho. In RODRÍGUEZ GARCíA, Nicolás.; FABIÁN CAPARRÓS, Eduardo A. (Coords) La corrupción en un mundo globalizado: Análisis interdisciplinar. Madrid: Ratio Legis, 2004.

ROMEIRO, Adriana. Corrupção e Poder no Brasil. Uma história, séculos XVI a XVIII. Coleção História e Historiografia. Belo Horizonte: Autêntica, 2017. Livro eletrônico formato e-pub não paginado.

ROSÁRIO, Wagner de Campos. O papel dos órgãos de controle interno na investigação conjunta de casos de fraude e corrupção na administração pública. In BARBUGIANI, Luiz Henrique Sormani. (Coord.) Corrupção como fenômeno supralegal. Curitiba: Juruá, 2017.

RUSCONI, Maxililiano A. Principio de inocencia e 'in dubio pro reo'. Texto da Conferência lida no Congresso Nacional sobre o Processo Penal organizado pela Universidade Diego Portales, em Santiago do Chile em 6 de novembro de 1997. 
Disponível no portal da Universidade de La Rioja em < https://dialnet.unirioja.es/servlet/articulo?codigo=174765 > acesso em 09 out 2020 .

SAINT-HILAIRE, Augustin François César Prouvençal de. Viagens pelo Distrito dos diamantes e Litoral do Brasil. Trad. De Leonam de Azeredo Pena. São Paulo: Companhia Editora Nacional, 1941.

SALGADO, Eneida Desiree. Lei de acesso à informação (LAl) - Comentários à Lei no 12.527/2011 e ao Decreto no 7.724/2012. Coleção direito administrativo positivo. Vol. 33. São Paulo: Atlas, 2015.

SAMPAIO, Kleber. Acidentes de trânsito matam 1,25 milhão de pessoas no mundo por ano. Nov. 2019. Disponível em: <http://agenciabrasil.ebc.com.br/economia/noticia/2019-10/brasil-e-o-71o-emranking-global-de-competitividade-indica-relatoratorio> Acesso em 23 fev 2020.

SANCINETTI, Marcelo. El delito de enriquecimiento ilícito de funcionario público sobre la inconstitucionalidad del Artículo 268 (2) del Codigo Penal Argentino. in EI derecho penal hoy. Homenaje a David Baigun. Buenos Aires: Editores del Puerto, 1996.

SANTOS, Cecília MacDowell (org.) A mobilização transnacional do direito. Portugal e o Tribunal Europeu dos Direitos Humanos. Coimbra: Almedina, 2012.

SCHÜLER, Fernando Luís; MÜLLER, Vinícius Bragança. O fim do tráfico negreiro e o maior crime da terra. In: BIASON, Rita; LIVIANU, Roberto (Organizadores) A corrupção na história do Brasil. São Paulo: Mackenzie, 2019. Livro eletrônico formato e-pub não paginado.

SCOTT. James. The Analysis of corruption in developing nations. Comparative Studies in Society and History. Vol. 11, No. 3 (Jun., 1969), pp. 315-341. Cambridge: Cambridge University Press. 1969.

SEGOVIA, Fernando. Declaração proferida no ato da assinatura do seu termo de posse como Diretor Geral da Polícia Federal. Disponível em: $<$ https://istoe.com.br/novo-diretor-da-pf-fala-em-corrupcao-sistemica-e-prometeampliar-operacoes/> Acesso em 08 jun 2019.

SESCA, Breno. 0 enriquecimento injustificado à luz das garantias constitucionais da presunção da inocência e da não autoincriminação. Revista da AJURIS - Porto Alegre: v. 45, n. 144, Junho/2018. Porto Alegre: AJURIS. 2018.

SILVEIRA, Daniel Barile da. Patrimonialismo e burocracia: uma análise sobre o poder judiciário na formação do Estado Brasileiro. Dissertação (Mestrado em Direito, Estado e Constituição) - Programa de Pós-Graduação em Direito. Brasília, Universidade de Brasília, 2006.

SILVEIRA, Daniel. No Brasil, $10 \%$ mais ricos ganham cerca de 17,6 vezes mais que os $40 \%$ mais pobres, aponta IBGE. Mai. 2018. Disponível em: <https://g1.globo.com/economia/noticia/2018/12/05/em-1-ano-aumenta-em-quase-2milhoes-numero-de-brasiLeiros-em-situacao-de-pobreza-diz-ibge.ghtml.> Acesso em 08 dez 2019. 
situação de pobreza, diz IBGE. Disponível em: <https://g1.globo.com/economia/noticia/2018/12/05/no-brasil-10-mais-ricos-ganhamcerca-de-176-vezes-mais-que-os-40-mais-pobres-aponta-ibge.ghtml> Acesso em 12 mai 2019.

SOUZA, Francisco Waldir Pires de. Projeto que criminaliza enriquecimento ilícito é aprovado. ago. 2007. Disponível em: < https://www.migalhas.com.br/quentes/44503/projeto-que-criminaliza-enriquecimentoilicito-e-aprovado > Acesso em 23 mai 2020.

STF. Notícias. Homologação de acordos de colaboração premiada no STF restituem mais de $\mathbf{R} \mathbf{\$} \mathbf{7 8 0}$ milhões em multas na Operação Lava-Jato. 11 dez 2018. In http://www.stf.jus.br/portal/cms/verNoticiaDetalhe.asp?idConteudo=398165. Acesso em 8 out. 2020.

STRECK, Lenio Luiz. Hermenêutica jurídica $\mathbf{e}(\mathbf{m})$ crise: uma exploração hermenêutica da construção do direito. Porto Alegre: Livraria do Advogado, 1999.

TARUFFO, Michele. La prueba de los hechos Disponível em: < https://www.academia.edu/35982613/la_prueba_de_los_hechos_michele_taruffo > Acesso em 23 jan 2019.

Rethinking the standards of proof. American Journal of Comparative Law 521(659). 2003.

TASSINARI, Davide. Nemo Tenetur se detergere. La libertà dalle autoincriminazioni nella struttura del reato. Bolonia: University Press, 2013.

TESOURO NACIONAL. Estimativa da carga tributária bruta em 2019 por espécie tributária e esfera de governo. Disponível em: <https://sisweb.tesouro.gov.br/apex/f?p=2501:9::::9:P9_ID_PUBLICACAO:32076>. Acesso em 03. Jun. 2019.

TOMÉ, Fabiana Del Padre. A prova no direito tributário. 2016. São Paulo: Noeses.

TORRES, Heleno Taveira. Trust não pode ser usado para sonegação fiscal. Disponível em: < in https://www.conjur.com.br/2015-nov-11/consultor-tributario-trustnao-usado-sonegacao-fiscal> acesso em 12 set 2019.

TORRES, Jaime Vegas. Presunción de inocencia y prueba en el proceso penal. Bilbao: La ley, 2002.

TORRES, Nelson Bassatt. La duda razonable en la prueba penal. Bilbao: Servicio Editorial Argitalpen Zerbitzua, 2007.

TORRES, Ricardo Lobo. O tribunal de Contas e o controle da legalidade, economicidade e legitimidade. Brasília, 31 n. 121 jan/mar 1994.

TRANSPARÊNCIA INTERNACIONAL. 25 escândalos de corrupção que abalaram o mundo. Jul. 2019. Disponível: < https://www.transparency.org/en/news/25corruption-scandals\# > Acesso em 15 set 2019. 
VARGAS GONZÁLEZ, Patrícia. Recuperación de activos procedentes de la criminalidad en Costa Rica. in GÓMEZ DE LA TORRE, Ignácio Berdugo; FABIÁN CAPARRÓS, Eduardo A. (Directores) Recuperación de activos y decomiso: reflexiones desde los sistemas penales iberoamericanos. Valencia: Tirant Lo Blanch, 2017.

VARNHAGEN, Francisco Adolfo. História Geral do Brasil. Revisão e notas de Rodolfo Garcia. 5a. São Paulo: Edições Melhoramentos: 1956.

VASCONCELLOS, Maurício Abijaodi Lopes de. O aprimoramento dos órgãos de estado como estratégia de prevenção da corrupção, fortalecimento da democracia e desenvolvimento do país. In BARBUGIANI, Luiz Henrique Sormani (Coord.). Corrupção como fenômeno supralegal. Curitiba: Juruá, 2017.

VERNENGO, Roberto J. Curso de teoría general del derecho. Buenos Aires: Depalma. 1986.

VIDALES RODRÍGUEZ, Caty. El delito del enriquecimiento llícito. Disponível em: $<$ http://caj.fiu.edu/publications/monographs/monograph10.pdf.> Acesso em 23 mar 2016.

VIEIRA, André Guilherme Delgado. A Petrobras e a "Operação Lava Jato". In: BIASON, Rita; LIVIANU, Roberto (Organizadores) A corrupção na história do Brasil. São Paulo: Mackenzie, 2019. Livro eletrônico formato e-pub não paginado.

VIEIRA, Antônio. Sermão proferido no domingo vigésimo segundo póspentecostes em 1652. in "Sermões do padre Antônio Vieira da Companhia de Jesus. Lisboa: Oficina de Miguel Deslandes, 1689, quinta parte. formato ePub. Sem paginação.

VILANOVA, Lourival. Causalidade e Relação no Direito. 4ª Ed. Revista, atualizada e ampliada. São Paulo: LRT, 2000.

Escritos jurídicos e filosóficos. São Paulo: Axis Mundi IBET, 2003.

Saraiva, 2005.

Estruturas lógicas e o sistema de direito positivo. 4" Ed. São Paulo:

WERNER, Guilherme Cunha Werner e Moises, José Álvaro. Corrupção na ditadura: alicerce da corrupção sistêmica de anos recentes. São Paulo: Mackenzie, 2019, Não paginado.

WITTGENSTEIN, Ludwig. Tratactus logico-philosophicus. São Paulo: Nacional, 1968. 
REFERÊNCIAS JURISPRUDENCIAIS BRASILEIRAS

BRASIL. Supremo Tribunal Federal. HC 45002/GB. Segunda Turma. Rel. Min. Aliomar Baleeiro. Publicação: DJ de 23.08.1968.

BRASIL. Supremo Tribunal Federal. HC 52819/BA. Primeira Turma. Rel. Min. Aliomar Baleeiro. Publicação: DJ de 22.11.1974.

BRASIL. Supremo Tribunal Federal. RHC 63.516/GO. Primeira Turma. Rel. Ministra. Néri da Silveira. DJ de 28.02.1986. Rel.: Min. Néri da Silveira, data de julgamento: 19.11.1986.

BRASIL. Supremo Tribunal Federal. Al 152.676 AgR. Segunda Turma. Rel. Min. Maurício Corrêa. Publicação: DJ de 3.11.1995.

BRASIL. Supremo Tribunal Federal. HC 77.135/SP. Primeira Turma. Rel. Min. IImar Galvão. Publicação: DJ de 6.11.1998.

BRASIL. Supremo Tribunal Federal. HC 78.708/SP. Primeira Turma. Rel. Min. Sepúlveda Pertence. Publicação: DJ de 16.04.1999.

BRASIL. Supremo Tribunal Federal. HC 102.473/RJ. Segunda Turma. Rel. Ministra. Ellen Gracie. Publicação: DJe de 02.05.2001

BRASIL. Supremo Tribunal Federal. HC 80.949. Primeira Turma. Rel. Min. Sepúlveda Pertence. Publicação: DJ de 14.12.2001.

BRASIL. Supremo Tribunal Federal. HC no 83.348/SP. Primeira Turma. Rel. Min. Joaquim Barbosa. Publicação: DJ de 28.11.2003.

BRASIL. Supremo Tribunal Federal. HC 83.096/RJ. Segunda Turma. Rel. Ministra. Ellen Gracie. Publicação: DJ de 12.12.2003.

BRASIL. Supremo Tribunal Federal. HC 83.542/PE. Primeira Turma. Rel. Min. Sepúlveda Pertence. Publicação: DJ de 26.03.2004.

BRASIL. Supremo Tribunal Federal. HC 85452 SP. Primeira Turma Rel. Min. Eros Grau. Publicação: DJ de 03.06.2005.

BRASIL. Supremo Tribunal Federal HC 87.478. Primeira Turma. Rel. Ministro Eros Grau. Publicação: DJ de 23.-2-2007.

BRASIL. Supremo Tribunal Federal. RE 482.006/MG. Tribunal Pleno. Rel. Min. Ricardo Lewandowski. Publicação: DJ de 14.12.2007.

BRASIL. Supremo Tribunal Federal. HC 92.634 PE. Primeira Turma. Rel. Ministra. Cármen Lúcia. Publicação: DJ de 15.02. 2008.

BRASIL. Supremo Tribunal Federal. RE 514.531/RS. Segunda Turma. Rel. Min. Joaquim Barbosa. Publicação: DJe de 06.03.2009. 
BRASIL. Supremo Tribunal Federal. HC 96.062/PR. Primeira Turma. Rel. Min. Marco Aurélio. Publicação: Dje de 13.11.2009.

BRASIL. Supremo Tribunal Federal. HC 84.078/MG. Tribunal Pleno. Rel. Min. Eros Grau. Publicação: DJ. de 26.02. 2010.

BRASIL. Supremo Tribunal Federal. ADC. no 3510 DF. Tribunal Pleno. Rel. Min. Ayres Britto. Publicação: DJe de 28.05.2010.

BRASIL. Supremo Tribunal Federal. HC 103.236/ES. Segunda Turma. Rel. Ministro Gilmar Mendes. Publicação: DJ de 3-9-2010.

BRASIL. Supremo Tribunal Federal. AP 470 AgR. Tribunal Pleno. Rel. Min. Joaquim Barbosa. Publicação: DJe de 08.10.2010.

BRASIL. Supremo Tribunal Federal. HC 103.683/MG. Primeira Turma. Rel. Ministra. Carmen Lúcia. Publicação: DJe de 25.11.2010.

BRASIL. Supremo Tribunal Federal. HC 98791/ES. Primeira Turma. Rel. Ministra Cármen Lúcia. Publicação: DJe 01.02.2011.

BRASIL. Supremo Tribunal Federal. INQ. 2.968/SP. Plenário. Rel.: Min Dias Toffoli, Publicação: DJe de 27.05.2011.

BRASIL. Supremo Tribunal Federal. HC 107370/SP. Segunda Turma. Rel. Min. Gilmar Mendes. Publicação: DJe de 22.06.2011.

BRASIL. Supremo Tribunal Federal. HC 99.289/RS. Segunda Turma. Rel. Min. Celso de Mello. Publicação: DJe de 04.08.2011.

BRASIL. Supremo Tribunal Federal AP 481/PA. Plenário. Rel. Min. Dias Toffoli. Publicação: DJe de 19/09/2011.

BRASIL. Supremo Tribunal Federal. RE 640.139/DF. Tribunal Pleno. Rel. Min. Dias Toffoli. Publicação: DJe de 14.10.2011, Repercussão Geral Reconhecida.

BRASIL. Supremo Tribunal Federal. RHC 107.915/SP. Primeira Turma. Rel. Min. Luiz Fux. Publicação: DJe de 16-11-2011.

BRASIL. Supremo Tribunal Federal. HC 106.957/RS. Segunda Turma. Rel. Min. Ayres Britto. Publicação: DJe de 07-12-2011.

BRASIL. Supremo Tribunal Federal. HC 104.410/RS. Segunda Turma. Rel. Min. Gilmar Mendes. Publicação: DJe de 27.3.2012.

BRASIL. Supremo Tribunal Federal. HC 101519/SP. Primeira Turma. Rel. Min. Luiz Fux. Publicação: DJe de 26.04.2012.

BRASIL. Supremo Tribunal Federal. HC 101.909. Segunda Turma. Rel Min. Ayres Britto. Publicação: DJe de 19.06. 2012. 
BRASIL. Supremo Tribunal Federal. AP 481/PA. Tribunal Pleno. Rel. Min. Dias Toffoli. Publicação: DJe de 29.06.2012.

BRASIL. Superior Tribunal de Justiça HC 246.885/SP. Rel. Min. Ari Pargendler. Publicação: DJ de 01/08/2012.

BRASIL. Supremo Tribunal Federal HC 112.388/SP. Segunda Turma. Rel. Min. Ricardo Lewandowski. Publicação: DJe de 14.09.2012.

BRASIL. Supremo Tribunal Federal. Al 856553 AgR-ED / BA. Primeira Turma. Rel. Min. Luiz Fux. Publicação: DJe de 10.06.2013.

BRASIL. Supremo Tribunal Federal. RHC 119.830/PR. Segunda Turma. Rel. Min. Gilmar Mendes. Publicação: DJ de 17.02.2014

BRASIL. Supremo Tribunal Federal. RE 583.523/RS. Tribunal Pleno. Rel. Min. Gilmar Mendes. Publicação: DJe de 22.10.2014.

BRASIL. Supremo Tribunal Federal. AP 678/MA. Primeira Turma. Rel. Min. Dias Toffoli,. Publicação: DJe de 05.02.2015.

BRASIL. Supremo Tribunal Federal. AP 595/SC. Primeira Turma. Rel. Min. Luiz Fux. Publicação: DJe de 10.02.2015.

BRASIL. Supremo Tribunal Federal. AP 421/SP. Primeira Turma Rel. Min. Luís Roberto Barroso. Publicação: DJe de 30.06.2015.

BRASIL. Supremo Tribunal Federal. HC 129.818/MG. Segunda Turma. Rel. Min. Dias Toffoli. Publicação: DJe de 21-10-2015.

BRASIL. Supremo Tribunal Federal HC 123.108/MG. Rel. Min. Luís Roberto Barroso. Publicação: DJe de 01.02.2016.

BRASIL. Supremo Tribunal Federal HC 123.734/MG. Tribunal Pleno. Rel. Min. Luís Roberto Barroso. Publicação: DJe de 02.02.2016.

BRASIL. Supremo Tribunal Federal. HC 123.533/SP. Tribunal Pleno. Rel. Min. Luís Roberto Barroso. Publicação: DJe de 18.02.2016.

BRASIL. SUPREMO TRIBUNAL FEDERAL. HC 126.292. Rel Min. Teori Zavascki Tribunal Pleno. Publicação: DJe de 17.05.2016.

BRASIL. Supremo Tribunal Federal. RE 126.292/SP. Tribunal Pleno. Rel. Min Teori Zavascki. Publicação DJe de 17.05.2016.

BRASIL. Supremo Tribunal Federal. RE 973.837/RG. Tribunal Pleno. Rel. Min. Gilmar Mendes. Publicação: DJe de 11.10. 2016. Repercussão geral reconhecida.

BRASIL. Supremo Tribunal Federal. RE 971.959/RS. Tribunal Pleno. Rel. Min. Luiz Fux. Publicação: DJe de 10.11.2016. Repercussão geral reconhecida. 
BRASIL. Supremo Tribunal Federal. AP 580/SP. Primeira Turma. Rel. Ministra. Rosa Weber. Publicação: Dje de 26.06.2017.

BRASIL. Supremo Tribunal Federal. AP 694/MT. Primeira Turma. Rel. Ministra. Rosa Weber. Publicação: DJe de 31.08.2017.

BRASIL. Supremo Tribunal Federal. AP 676/MT. Primeira Turma. Rel. Ministra Rosa Weber. Publicação: Dje de 06.02.2018.

BRASIL. Supremo Tribunal Federal. AP 985/MT. Segunda Turma Rel. Min. Edson Fachin. Publicação: DJe de 08.03.2018.

BRASIL. Supremo Tribunal Federal. AP 883/DF. Primeira Turma. Rel. Min. Alexandre de Moraes. Publicação: Dje de 05.04.2018.

BRASIL. Supremo Tribunal Federal. AP 996/DF. Segunda Turma Rel. Min. Edson Fachin. Publicação: DJe de 01.06.2018.

BRASIL. Superior Tribunal de Justiça. RHC no 97.816. Rel. Min. Maria Thereza de Assis Moura. Publicação: DJE de 08.05.2018.

BRASIL. Supremo Tribunal Federal. AgR HC 152951/SP. Primeira Turma. Rel. Min. Luís Roberto Barroso. Publicação: DJe de 06.08.2018.

BRASIL. Supremo Tribunal Federal. MC ADC 43/DF. Tribunal Pleno. Rel.: Min. Marco Aurélio. Publicação: DJe de 28.09.2018.

BRASIL. Supremo Tribunal Federal. INQ 4.657/DF. Segunda Turma. Rel. Min. Gilmar Mendes. Publicação: DJe de 15.10.2018.

BRASIL. Superior Tribunal de Justiça. REsp 1765139/PR. Rel. Min. Felix Fischer. Publicação DJe de 26.11.2018.

BRASIL. Supremo Tribunal Federal. AP 1003/DF. Segunda Turma. Rel. Min. Edson Publicação: Fachin. DJe de 06.12.2018.

BRASIL. Supremo Tribunal Federal. HC 171.536/MG. Rel.: Min. Luiz Fux. Publicação: DJe de 28.05.2019.

BRASIL, Supremo Tribunal Federal. AP 968/SP. Segunda Turma. Rel. Min Luiz Fux. Publicação: DJe de 02.08.2019.

BRASIL. Supremo Tribunal Federal. HC 155.984/SC. Primeira Turma. Rel. Min. Marco Aurélio. Publicação: DJe de 16.07.2020. 
SÚMULAS DO SUPREMO TRIBUNAL FEDERAL

BRASIL. Supremo Tribunal Federal. Súmula no 716: Admite-se a progressão de regime de cumprimento da pena ou a aplicação imediata de regime menos severo nela determinada, antes do trânsito em julgado da sentença condenatória.

BRASIL. Supremo Tribunal Federal. Súmula no 717: Não impede a progressão de regime de execução da pena, fixada em sentença não transitada em julgado, o fato de o réu se encontrar em prisão especial. 